Florida International University

FIU Digital Commons

FIU Electronic Theses and Dissertations

University Graduate School

$3-23-2010$

\title{
Trading Democracy for Security? The Effects of the International Drug War on the Quality of Democracy in the Dominican Republic, 1996 $-2008$
}

Leah H. Blumenfeld

Florida International University, Leah@blumenfelds.us

DOI: $10.25148 /$ etd.FI10041602

Follow this and additional works at: https://digitalcommons.fiu.edu/etd

Part of the International and Area Studies Commons, and the International Relations Commons

\section{Recommended Citation}

Blumenfeld, Leah H., "Trading Democracy for Security? The Effects of the International Drug War on the Quality of Democracy in the Dominican Republic, 1996 -2008" (2010). FIU Electronic Theses and Dissertations. 165.

https://digitalcommons.fiu.edu/etd/165 


\section{FLORIDA INTERNATIONAL UNIVERSITY \\ Miami, Florida}

TRADING DEMOCRACY FOR SECURITY? THE EFFECTS OF THE

INTERNATIONAL DRUG WAR ON THE QUALITY OF DEMOCRACY IN THE

DOMINICAN REPUBLIC, 1996 - 2008

A dissertation submitted in partial fulfillment of the

requirements for the degree of

DOCTOR OF PHILOSOPHY

in

POLITICAL SCIENCE

by

Leah Hutton Blumenfeld

2010 
To: Dean Kenneth Furton

College of Arts and Sciences

This dissertation, written by Leah Hutton Blumenfeld, and entitled Trading Democracy for Security? The Effects of the International Drug War on the Quality of Democracy in the Dominican Republic, 1996 - 2008, having been approved in respect to style and intellectual content, is referred to you for judgment.

We have read this dissertation and recommend that it be approved.

Astrid Arraras

Harry D. Gould

Dario Moreno

Eduardo Gamarra, Major Professor

Date of Defense: March 23, 2010

The dissertation of Leah Hutton Blumenfeld is approved.

Dean Kenneth Furton
College of Arts and Sciences

Interim Dean Kevin O'Shea

University Graduate School

Florida International University, 2010 


\section{DEDICATION}

I dedicate this dissertation to Earl. 


\section{ACKNOWLEDGMENTS}

I wish to thank: my parents for always supporting my academic pursuits; my husband for never worrying about my academic ability even when I did; the faculty, staff, and students of Political Science and the Women's Studies Center; the dissertation committee

for their input, patience, and connections; Josefina Reynoso Chicón, Bielka Polanco and the Newlink staff, Manny and Marilyn, and all the other Dominican citizens I encountered during my field work whose contributions informed this work both directly and indirectly. 


\author{
ABSTRACT OF THE DISSERTATION \\ TRADING DEMOCRACY FOR SECURITY? THE EFFECTS OF THE \\ DOMINICAN REPUBLIC, 1996 - 2008 \\ by \\ Leah Hutton Blumenfeld \\ Florida International University, 2010 \\ Miami, Florida \\ Professor Eduardo Gamarra, Major Professor
}

INTERNATIONAL DRUG WAR ON THE QUALITY OF DEMOCRACY IN THE

The purpose of the research is to study the relationship between international drug interdiction policies and domestic politics in fragile democracies, and to demonstrate how international drug control policies and the use of force fit the rhetoric of war, are legitimized by the principles of a just war, but may also cause collateral damage and negative unintended consequences. The method used is a case study of the Dominican Republic. The research has found that international drug control regimes, primarily led by the U.S. and narrowly focused on interdiction, have influenced an increasingly militarized approach to domestic law enforcement in the Dominican Republic. The collateral damage caused by militarized enforcement comes in the form of negative perceptions of citizen security, loss of respect for the rule of law and due process, and low levels of civil society development. The drug war has exposed the need for significant reform of the institutions charged with carrying out enforcement, the police force and the judicial system in particular. The dissertation concludes that the extent of drug trafficking in the Dominican Republic is beyond the scope of domestic reform 
efforts alone, but that the programs implemented do show some potential for future success. The dissertation also concludes that the framework of warfare is not the most appropriate for the international problems of drug traffic and abuse. A broader, multipronged approach should be considered by world policy makers in order to address all conditions that allow drugs to flourish without infringing upon democratic and civil rights in the process. 


\section{TABLE OF CONTENTS}

CHAPTER

I. INTRODUCTION 1

II. LITERATURE REVIEW 7

Drugs, Democracy, and the NUCs of Militarization 7

Drugs, Security, and Democracy 11

$\begin{array}{ll}\text { Levels of the Drug War Game } & 16\end{array}$

$\begin{array}{ll}\text { Conclusions } & 19\end{array}$

III. THEORETICAL CONSIDERATIONS 20

Is the War on Drugs a Just War? $\quad 20$

Changing Paradigms in IR and Definitions of Security 37

Conclusions $\quad 45$

IV. MODERN DRUG POLICY IN HISTORICAL CONTEXT 46

Drugs in the Americas: A Brief History 46

U.S. Drug Policy: The Baseline 78

Evaluation \& Conclusions $\quad 98$

V. THE DOMINICAN REPUBLIC AS A CASE STUDY 101

A Brief History of Democracy in the Dominican Republic 104

Dominican Democracy and Institutions 114

U.S. Assessment of the Dominican Republic: The INCSR 119

$\begin{array}{ll}\text { Democracy and Public Opinion } & 133\end{array}$

$\begin{array}{lr}\text { Conclusions } & 139\end{array}$

VI. THE DOMINICAN CASE ON THE GROUND 141

Internal Evaluations of the PSD 145

Press Evaluations of the Drug Predicament 157

$\begin{array}{ll}\text { Independent Evaluations of the PSD } & 162\end{array}$

$\begin{array}{ll}\text { Conclusions } & 195\end{array}$

$\begin{array}{ll}\text { VII. DISCUSSION } & 199\end{array}$

$\begin{array}{ll}\text { Security and Democracy } & 199\end{array}$

$\begin{array}{ll}\text { Just War Theory Revisited } & 207\end{array}$

$\begin{array}{ll}\text { Conclusions } & 217\end{array}$

Epilogue -- War on Supply vs. War on Demand: Policy Alternatives 220

LIST OF REFERENCES 226

$\begin{array}{ll}\text { VITA } & 235\end{array}$ 


\section{Introduction}

The state is the institution with a monopoly on the legitimate use of force-Max Weber In a democracy the citizen is responsible for the kind of military the state possesses and how it is used-Michael Walzer

Those who would give up essential liberty to purchase a little temporary safety, deserve neither liberty nor safety - attributed to Benjamin Franklin

This dissertation examines the relationship between international drug interdiction policies and domestic politics in fragile democracies through a case study of the Dominican Republic. It also seeks to demonstrate how international drug control policies and the use of force fit the rhetoric of war, and are legitimized by the principles of a just war, but may cause collateral damage and negative unintended consequences. As LaMond Tullis wrote in 1995, the way that drug related laws "combine to create unintended socioeconomic and political consequences ought not to be surprising. The dimensions of the consequences, however, may be alarming" (135). The main purpose of this dissertation is not to measure whether we are winning or losing the war on drugs, but rather whether a policy of war is justified at all.

The international drug trade has remained a salient issue for international relations in general, as involvement in the trade and efforts to deal with it are not uniform in all states, but nearly all states are affected by drugs in some way. In the late $20^{\text {th }}$ century, drug traffic was the fastest growing area of international crime and a primary concern behind new legislation and the organization of law enforcement (Dorn, et al., 1992). Much scholarship on the relative success of the drug war measures the stated objectives of policy. This research contributes to a growing literature on the unanticipated effects of policy, and demonstrates the ways that a policy in one issue area can have effects 
elsewhere. By doing so, we can demonstrate how framing a policy in a single-minded way limits options and chances for success.

Drugs are prominent but relatively understudied in academia; further it is a topic that is under-theorized and ideologically polarized (Hinojosa, 2007). Indeed, drug policy tends to follow one path in the United States - that of keeping drugs from crossing into U.S. territory. Drug producing and trafficking countries are often thought to be synonymous with developing and less-developed countries. Yet even in the 1990s Tullis (1995) pointed out that "the distinctions between producing and consuming countries have materially decreased" and that "much less is known (either in quantitative or qualitative terms) about the impact of drug production, consumption, and trade in developing countries" (vii). Alternative strategies are rarely discussed, and this has numerous implications for other states, particularly those that rely on the U.S. to aid their own anti-drug efforts.

Further, while drugs are not usually conceived of as a traditional security issue, the specter of geonarcotics is a threat to the security and sovereignty of states, especially in the Caribbean basin:

Drug related problems [are] the single most important serious security issue confronting the internal order of Caribbean nations, their regional policies with other Caribbean states, and their international relations with the United States and European powers" (Brana-Shute, 2000: 98).

But security for the state is not the same as security for those within it, and the concept of the drug problem has changed over time in U.S. government circles. It has morphed from being a concern of health, to crime, to a matter of national security. As a matter of national security it was then only a small step to calling responses to drugs war. In places 
where democracy is not long-established, the use of force to combat drugs has the potential for abuse and to compromise state-society relations. A measure of tension exists between domestic political responsibilities and international obligations for leaders in the Dominican Republic. If the United States is leading a militarized drug war in the Caribbean, then what is at stake in the Dominican Republic where democracy, human rights, and civil liberties are already fragile?

\section{Methods, Data, and Significance of the Study}

The following are the main research questions that will be addressed:

Question \#1: Is the international war on drugs a just war?

Question \#2: Are efforts to implement policies in the war on drugs a threat to democratic practices and civil liberties?

Question \#3: Are domestic political concerns congruent with international concerns? From these questions three hypotheses follow:

Hypothesis \#1: The war on drugs is not uniformly just in all areas where it is fought.

Hypothesis \#2: Police and military efforts to confront the drug problem are implemented at a cost to due process and civil liberties in fragile democracies.

Hypothesis \#3: Domestic political and economic concerns are addressed by state leaders secondarily to international concerns.

The method for testing the hypotheses above will be through a case study of the Dominican Republic. The research covers a roughly 12-year period beginning in 1996 with the election of Dominican President Leonel Fernández. This election represents the 
beginning of a successful transition to democracy, and precedes the implementation of Plan Colombia and the Andean Initiative, the benchmark of U.S. counter-drug policy.

To address these questions, the following chapters include a history of drugs in the Western Hemisphere and an evaluation of U.S. policies, including the State Department's International Drug Control Strategy. In conjunction with this, I review components of Dominican policy, especially those laws and enforcement practices supported by the U.S. I also evaluate the role of Dominican reform policies aimed at bringing the presence of the state back to the national territory and reforming the police and judicial systems, while building civil society and preserving inchoate democratic practices. The examination will assess whether or not these policies and their related enforcement guidelines adhere to the principles of a just war and achieve their stated goals.

In relation to this, and to the second and third questions above, democracy is a large term that does not lend itself to a simple definition or obvious, universal measurements. As the dependent variable in this study, I will attempt to assess it through measurements of several democratic indicators. In the Caribbean context, democracy exists alongside deep poverty and inequality. The work of securing civil and social rights is intricately linked to consolidation of political rights. A small state and new democracy like the Dominican Republic has the challenge of addressing internal concerns for economic and civic development, while confronting both internal and external pressures to engage in the drug war - and to do it all with limited resources.

Measures of democracy usually entail an examination of electoral processes. Interest in democracy and common measures for it do not necessarily accurately reflect 
how democratic a society is. Bollen (1991) argues that various political rights and liberties within a society can indirectly gauge and reflect the power that groups have. For him, rights are the characteristics of the electoral system, and liberties are the freedom of the population within the political system, including the media and the opposition. While many scholars have tended to emphasize rights over liberties, or vice-versa, I would add that little attention is given to elite power in the military and the judiciary in addition to those areas of elite activity that are considered political. It is even less often that the police are included and truly examined as a part of the judicial branch and as having influence over liberties. Thus, political democracy could be decreased if rights are high but liberties are infringed upon by law enforcement, or if law enforcement is incapable of protecting those rights and liberties. Therefore, this study looks at judicial and law enforcement institutions, especially efforts to implement improved codes of criminal procedure in Dominican law and to reduce or eliminate corruption within the system. The quality of a democratic system can also be measured by the confidence citizens have in their institutions. These include the executive, the judiciary, the police, and the military, as well as confidence in the economy. Equally important are participation in politics, perceptions of corruption within governing and civil institutions, and the administration of justice in general. These items together make up an index for citizen support of democracy. Confidence in the system and institutions includes citizen perceptions of security. This study uses public opinion data, recently gathered by Dominican research groups such as Newlink and Centro Juan Montalvo, as a way to gauge both citizen perceptions of their governing institutions, as well as their own security and freedom within their daily lives as Dominican citizens. Data from within the 
institutions of interest offers an additional and often contrasting perception and evaluation of the level of citizen security, civil society, and civil institution development.

The nexus of the domestic and the international is not easily disentangled but a case study, done properly and carefully, can shed light on its particulars as well as inform other studies elsewhere. While some argue that there is little truly cross-national research on drugs and drug policies, the more individual case studies are done, the more knowledge about their effects can be generated, and some generalizations can be made (MacCoun and Reuter, 2002). This study will contribute to that body of knowledge and may have implications for democracy in the region as a whole. Most of the countries in Central and South America are coping with the drug trade, as are European and other nations the world over. By looking at both the domestic political effects and the international context in which they take place, we can begin to see the constraints placed on all leaders as they struggle with a complex transnational issue. 


\section{The Historical Context: A Literature Review}

This chapter reviews the body of scholarly literature on the questions about drugs, democracy, and state and citizen security. By seeing how these questions overlap and have been approached by academics, I will begin to show where my interest in justice fits into the discussion of the war on drugs, and ultimately whether war is the most appropriate and efficient method for combating drug traffic.

\section{-- Drugs, Democracy, and the NUCs of Militarization --}

In the U.S. drugs are seen as a threat to the country from the outside, and the narrow focus of U.S. drug control strategy is to stop the flow of drugs into the U.S. by combating production in and shipment from source countries. Elsewhere by contrast, drug production takes root in poor and weakly institutionalized areas in response to the huge demand for drugs in the U.S. and Europe and their resulting profitability. By supplying money and military training to those who cooperate, the war on drugs is then quite literal in these areas. In addition, "U.S. military and police assistance" tend "to take priority over aid for socioeconomic goals or democratic institutions" (Youngers and Rosin, 2005: 4). In other words, the military approach to drugs as a security threat to the state is separate from any approach that would address elements of human security for many of those involved in the drug trade.

War terminology is a powerful metaphor but a poor and problematic guide for policy:

The drug war mentality ensures that U.S. drug control resources are skewed toward interdiction and law enforcement efforts. But such policies, which fail to take into account the complex social and economic roots of both illicit drug 
production and consumption, tend to shift the pattern of players in the drug trade without significantly reducing the trade itself (Youngers and Rosin, 2005: 4).

As more time passes and the trade grows, the distinction between producing and consuming areas becomes less clear, while the positive effects of economic development and democracy-building programs may be "undermined by the unexamined consequences of U.S. military and police assistance" (ibid.: 5).

Collateral damage in the war on drugs is "extensive" while its impact on the availability of drugs in the U.S. is "marginal at best" (Youngers, 2005: 339). Cases studied throughout Latin America show,

U.S. drug control policies have contributed to confusing military and law enforcement functions, militarizing police forces, and bringing the military into a domestic law enforcement role. They have thus strengthened military forces at the expense of civilian authorities (ibid.: 340).

In the U.S., policy goals and measures are good for domestic politics, both for campaigns and for maintaining program budgets, but they do not seem to address whether any real progress is made.

Adam Isacson (2005) argues that historically the U.S. sees the Latin American region as a source of threats rather than an area with potential for cooperation and development. For this reason, policy frequently turns to militaries to solve problems. As part of the Andean Strategy, the U.S. has encouraged Latin American militaries to take on roles that would be unthinkable for the U.S. military at home. This is an especially problematic tactic during a time of democratic reform throughout the region.

“Many analysts view the U.S. military's expanded domestic drug war powers as a dangerous erosion of the posse comitatus principle" (Isacson, 2005: 33). I would add that it also creates a bad precedent and sets a poor example for other countries combating 
drugs. Isacson points out that some legislators and military personnel in the U.S. have even suggested that principles like posse comitatus should be re-examined or changed if they limit what a government can do to protect its people. The implications of this kind of thinking are troubling, especially within the U.S. where democracy is supposed to be entrenched and unwavering. "If this principle [posse comitatus] is being eroded in Washington, the damage is likely to be far greater in the rest of the hemisphere" (ibid.: $53)$.

In 2002, the Dominican Republic ranked among the top ten recipients of U.S. military training (Isacson, 2005). Colombia is the number one recipient of U.S. military and police aid - and it also serves as the basis for how the U.S. understands the region as a whole in the war on drugs. It serves as the benchmark for the emphasis on military, security, and counter-insurgency approaches. Further, during the Bush administration the war on drugs became synonymous with the war on terror. Some fear that the increased unregulated military aid and the latitude to name various groups "terrorists" are likely to harm peaceful opposition to government in Latin America. This latitude is also likely to circumvent due process in the name of controlling terrorism.

The Caribbean is a "transit zone" within the U.S. policy framework. One point of contention has been the U.S. military presence in the region and the role of the military in counter-drug measures. A second point of contention concerns the definition of national security for the states involved and the fact that the anti-drug mission is dominant in the U.S. security agenda for the region. Caribbean leaders are often critical of the militarized approach and instead propose a multidimensional security approach that addresses the social, health, and trade problems associated with drugs and drug trafficking. As counter- 
terrorism is superimposed on counter-drug efforts, many Caribbean leaders fear that the multiple dimensions of security - the problems of poverty, unemployment and so on will be abandoned further from the narrow focus of U.S. policy in the name of terror.

In addition, the emphasis on terror takes away from the development of democratic institutions, including police reform and the development of democratic policing where forces adhere to principles of accountability, transparency, and responsiveness to their communities. This kind of reform is important because historically the militarization of police forces is characteristic and profound in Latin America (Neild, 2005). Many foreign police forces receive military training from the U.S. at WHINSEC (formerly known as the School of the Americas) and with money from the State Department or Pentagon budget. "Military training of police goes directly against efforts across the region during the 1980s and 1990s to bring police under civilian control and increase accountability," and military tactics and skills are "profoundly antithetical to democratic policing standards" (ibid.: 69-70). Officers need to be able to act through their own judgment and communication skills rather than use force and obey a command hierarchy as do soldiers on a battlefield. While police training may be helpful to DEA operations abroad, it "has not proven an adequate tool to deal with local police corruption" (ibid.: 74).

In theory, supply suppression could be successful with additional use of force, but in most of the main supply or trafficking regions, significant external inputs would be necessary. A more ambitious war on drugs may have some success in the target country, but so far efforts usually succeed in displacing traffic rather than eliminating it.

Examples abound, from Mexico's highly successful eradication programs in the 1970s, to 
Thailand's success at reducing heroin production in the early 1990s while neighboring Laos and Myanmar increased theirs (Craig, 1981; Tullis, 1995). As long as the market is viable, the production side will migrate to the areas of least resistance.

\section{-- Drugs, Security, and Democracy --}

The Dominican Republic is "the clearest example" of the eroding distinction between military and police tasks, where the U.S. encourages security forces to become involved in anti-drug and law enforcement tasks that would be illegal in the U.S. (Beruff and Cordero, 2005: 320). The military is in charge of the Dirección Nacional de Control de Drogas (Office of National Drug Control or DNCD), whose directors are high ranking officers. Beruff and Cordero (2005) suggest that because the largest drug busts in the Dominican Republic occur in the capital city of Santo Domingo and in the eastern region, rather than along the Haitian border or any other permeable geographic area in the country (of which there are many), "the drug trade has penetrated the upper echelons of the Dominican government" (321). Thus, the enemy in the war on drugs exists within the same institutions as our allies.

The infiltration of trafficking hastens processes of social disorganization through its systemic and corruptive effects. Tullis's (1995) examination of the cases of Colombia and Bolivia shows that "traditional values are eroded as illegality permeates a society, violence becomes a way of life, and people become less inclined to accept norms on which consensual politics (including liberal democracy) rest" (170). Drug traffic brings more violence and this increasing violence "severely weakens each country's efforts to create modern democratic institutions" (ibid.: 171). This argument supports the idea that 
drugs are a threat to democracy, but complicates international efforts to use local military and police institutions to control local traffic.

A democracy requires more than just the holding of elections. In a citizenship democracy, the electoral system is based in a society that supports the political and civil rights of each of its citizens. The society also has some measure of existential security through policies and programs that address poverty, unemployment, or inequality, and incorporate marginal or previously excluded sectors into the system to some degree. Election results have meaning and citizens participate when they know they are free to make their own voting choices, the results will be respected, and no change in leadership will diminish their rights or destroy the system.

As the Dominican Republic made its transition to democracy during the 1990s, the necessary conditions for democratic consolidation remained "unincorporated" in Latin America (Rogers, 1999: 39). Instead, what are labeled "perverse" democratic processes have allowed drug traffic and other illicit activities to persist (ibid.: 40). Drugs are a threat to democracy on two fronts - money and its associated corruption, and the militarization of efforts to combat the trade (ibid.). Indeed, "drug corruption is now a major threat to democratic [re]construction in many parts of the world" (Griffith, 1997: 9). These words continue to be true today as drug-related violence "undermines and wrecks the institutional basis for the maintenance of good government and public safety" both in the Western hemisphere and in the face of democratization efforts in the middle east and central Asia (ibid.: 8). But if war is the legal equivalent of violence, is it good policy to fight fire with fire? 
Using Puerto Rico as a case study, Jorge Rodriguez Beruff (2000) has examined the "political consequences of drugs-driven state restructuring, particularly in relation to security policy and forces" (162). He notes that post-Cold War security includes nontraditional issues such as drug traffic. While Puerto Rico differs from other Caribbean states because of its relationship to the U.S. and its geostrategic position, some aspects similar to other cases can be seen. His finding - that drug interests are not undermining the state in spite of related problems of crime and corruption - is the opposite of what one would expect and presents an interesting comparison and perhaps cautionary example. In Puerto Rico, "anti-drug strategies may have had the effect of strengthening state power and its instruments of force" (ibid.: 163). The concern then is less with governability than an emerging authoritarianism.

Beruff cites the growth of criminality and violence in Puerto Rico since the 1950 's, and public opinion polls that show the perception of the relationship between drugs and violence from the 1970's on. Crime has increased especially in housing projects and urban areas. By 1992, there was broad popular support for gubernatorial candidate (and eventual winner) Pedro Rosseló's "strong hand against crime and drugs" platform (Beruff, 2000: 167). He advocated harsher punishments, larger police budgets, and the use of the National Guard to combat the problem. His hard-line approach was "also in line with the stronger anti-crime and anti-drug policies in the United States, and with mounting federal concern regarding the role of the island (and neighboring U.S. Virgin Islands and the Dominican Republic) in drug trafficking" (ibid.: 167-168). The implementation of the president's plan involved sending forces to occupy several housing projects. Occupation by National Guard and police forces brought increased arrests and 
seizures of drugs, but no decrease in murder or other violence. Further, none of the policy measures "shielded the middle-class neighborhoods from robberies and drugrelated executions" (ibid.: 171). Much of the criminal activity simply relocated. The enforcers themselves were not immune from corruption, and by the late 1990s funding for these operations had dropped even as drug traffic to the United States was increasing. Additional polling data after five years of strong-hand policies showed that the majority felt the problem had gotten worse. A study like this demonstrates how the anti-crime, anti-drug agenda is legitimizing and allowing for the emergence of a military-police complex but one that does not appear to be able to fulfill its mission to reduce drugs and crime (ibid.: 176). Increased militarization did not bring with it increased democracy or citizen security.

According to Kincaid and Gamarra (1996), the pattern in the Latin American region is "a recourse to military intervention in support, and in place, of normal police responsibilities" $(211)$. The pattern differs in the late $20^{\text {th }}$ century from earlier periods in that it is done with the initiative of civilian elected governments rather than along with coups and dictatorships. In other words, there is now some level of civilian control over the military even as the pattern persists. The authors argue that although the pattern is not necessarily unusual from a world perspective, or contradictory to democratic norms, the cases they examine do suggest a new model of public security "with significant and unfavorable implications for the institutions and practices of democracy" (ibid.: 212).

The military is generally given the responsibility for national security or defense, and police are in charge of public security, where the definition of public security is "the maintenance of public order and the enforcement of laws" (Kincaid and Gamarra, 1996: 
212). There are some exceptions; militaries often have the capacity to intervene when conditions exceed police capabilities, such as during natural disasters or large-scale riots. The problem Kincaid and Gamarra find is when the exceptions become the norm - when government authority declares a state of emergency or state of siege because of widespread opposition to a particular policy or increased levels of violence and crime in relation to drugs. The government calls upon the military to intervene in what are ongoing conditions of unrest or normal law enforcement issues, rather than temporary and acute crises.

Military forces are also generally charged with the function of protecting collective interests, those of the nation as a whole. Thus when they enter into a public security function it is "likely to be accompanied by the suspension or downgrading of some citizen rights" (Kincaid and Gamarra, 1996: 213). In the case of a single riot or disaster, this downgrade would again be temporary. With the issue of drugs comes the potential to suspend citizen rights indefinitely. And when there are no citizen rights or individual security, there can be no democracy. The trend of "policization" of the military, to borrow Kincaid and Gamarra's word, appears to be happening in the Dominican Republic. A merging of police and military roles has appeared and neighborhoods often still resemble war zones even as reform programs progress.

Kincaid and Gamarra are skeptical about the ability of a military presence to deter crime and violence, especially in the long run. In the Dominican Republic organized crime is likely to diversify, as they have at least as many resources to work with as do the enforcement bodies. Further, broader economic conditions have placed a toll on the general population and provided a space for drug money to infiltrate. Militarization is a 
possible remedy but unlikely cure for these deeper causes and conditions. The Dominican government's plan attempts to cover some of these other causes, but as Kincaid and Gamarra point out, far-reaching changes are needed to address all factors of the public security crisis in order to reduce violence overall.

\section{-- Levels of the Drug-War Game --}

In a book about the U.K.'s domestic drug market, Dorn et al. (1992) reject the notion that drug traffic is dominated by large organizations such as cartels or the mafia. They focus instead on the numerous smaller actors and connections between them and law enforcement. Their book focuses on the nature of traffic and trade in the U.K and recognizes the inherent difficulties of studying the illicit. They also examine the nature and structure of enforcement and whether there is an equitable application of penalties.

The authors are concerned with the development of a national police force in the U.K. as a response to drug crime and are "critical of the upward escalation in imprisonment that characterizes most developed countries' response to drug trafficking" (Dorn et al., 1992: xvii). They describe first the "Mr. Big" strategy which goes after the major dealers and organizers, and is the priority of DEA and other U.S. operations. This strategy is familiar but problematic in that there seems to be no set definition of how 'big' a big target must be. The strategy may disrupt the flow of traffic but does not necessarily stop all drugs from entering the market. It may target individuals who are visible but not necessarily the top organizers, and there are always new 'godfathers' in training ready to step into their places. 
Indeed, traffickers are adept at developing counter-strategies. Dorn et al. note a "tendency for traffickers to keep their organisations small and flexible, an understandable response to enforcement that for several decades announced its commitment to immobilizing large organisations" (1992: 75). Where there has been some move to middle- and lower-level enforcement, one can expect to see similar new counterstrategies as "drug markets and law enforcement continuously interact and shape one another" (ibid.: 75). By extension, one might also expect an increase in militarized efforts by drug enforcement bodies to be met by additional military-style and violent resistance, or by vigilante justice.

The formal organizational structure of the police force and its operations is only part of the drug enforcement story. Informal aspects, particularly the organizational culture, are just as important:

On the one hand there are acceptably creative interpretations of formal rules and regulations. On the other there are ways of working that come to be defined as unacceptable because either they result in successful legal challenges by defence lawyers in court, or they cause difficulties for other enforcement officers or operations, or they may become indistinguishable from corruption. The line between creativity and corruption can be a narrow one (Dorn et al., 1992: 119).

In other words, enforcement personnel may bend or break the rules themselves in their efforts to find and punish traffickers. How far they can bend the rules, or whether they can break them, depends on the level of toleration within their units or the justice system as a whole. In some cases, the informal or corrupt organizational structure can appear to overtake the formal-legal one, whether real or perceived. If police are viewed by others or themselves as being above the law, an additional set of problems can arise, compounding those already brought on by crime itself. The policies to be investigated 
here make this point particularly relevant for the Dominican Republic since the data deals directly with official corruption, police practices, and the public perceptions of them.

Similar to Dorn et al. (1992), Payan (2006) argues that modern government agencies are bureaucratic, and have rigid standard operating procedures and vertical structures that make it difficult to respond to the versatile, flexible, and horizontal structure of drug organizations. Organizational theory provides two perspectives from which to study agency behavior in the war on drugs. These are 1) bureaucratic politics, in the style of Graham T. Allison's Essence of Decision, and 2) organizational culture. The bureaucratic politics approach argues that policy choice is a political result and not necessarily the best choice in every case. The organizational culture approach seeks to demonstrate that values and norms within an organization may be either conducive or detrimental to the execution of a policy - or a reason that reform efforts fail.

Organizational culture is treated as something complex that emerges over time, and is something that requires additional time to change once it has been established. Culture stems from the social need the organization is created to fulfill (Payan, 2006). For this study I ask what the primary purpose the Dominican National Police was created to fulfill. It may have been the protection of the public on the one hand, but it could also have been for the protection of elites, leaders, and their interests. The missions and tasks of an organization are important, as are the training and socialization systems that prepare the newest members of the organization to do their duties - and to fit in with everyone else already there. These systems may be formal or informal and will affect how members of the institution fulfill their duties and the mission of the organization. New 
members may also confront conflicts between their formal training and the actual practices within the organizational structure and hierarchy.

\section{Conclusions}

As this literature shows, the framing of the drug war has been an important element of its execution. The war has focused on an outward military strategy against a foreign threat, and scholarly interest has lain in evaluating the effectiveness of a militarized approach and its influence over domestic institutions and civil society. The literature suggests that drug organizations and violence may be a threat to states through corruption, but that hard-line policies have not been able to eliminate this corruption nor dismantle the drug trade or dealing at any level. Repressive measures from the state have the unintended and negative potential to cut off civil liberties, limit citizen security, and harm the rights of people and the democratic system they were designed to protect. Even more troubling are the assertions made by those in power that these trade-offs are necessary. Finally, the nature and structure of the drug trade, the internal characteristics of the organizations charged with its control, and the broader national contexts in which the drug trade flourishes have been less well addressed. 


\section{Theoretical Considerations}

Is war the right policy for dealing with international drug traffic? To answer this question one needs a framework through which to view and assess the war on drugs, and a way to evaluate a level of justice within U.S. policy, Dominican policy, and reform to its systems. In this chapter, I will examine both just war theory in the Western tradition as it relates to the war on drugs, and conceptions of security in International Relations and their relevance and importance to the international drug trade.

\section{Is the War on Drugs a Just War?}

Politicians in the U.S. have frequently used the rhetoric of war when framing an issue: the War on Poverty, the War on Drugs, and the War on Terrorism. This section explores just war doctrine as a way to measure the legitimacy of the drug war in action. Just war doctrine has ancient roots but is embodied today in generally accepted international protocols for the conduct of war. The war on drugs, while not the necessarily the same type of war covered by these protocols, has become heavily militarized in its conduct. Temes (2003) uses the expression 'just war thinking' as a way to capture a kind of moral thinking about war that is less formalized than theory or doctrine as laid out by various philosophers or the catholic church. I borrow his phrase here to refer to trends among just war philosophers rather than using any single one of their formulations. This less formal approach can be more easily applied to a pseudo-war like the war on drugs than a declared war with similar rhetoric.

This study works on the premise that the use of force in the context of narcotics control has caused collateral damage and negative unintended consequences. Michael 
Walzer (1977) argues that a Thucydides-style realism about war is "a denial of the freedom that makes moral decision possible" (10). To do what one is capable of doing is a choice and is not necessarily inevitable. Thus, the resort to force in the war on drugs is a matter of choice, not fate, for policy makers. I argue that the reasons for waging a war on drugs may be considered just, while the conduct of the war itself is not just and the desired results are unattainable. I will begin here with a history of just war thought and a discussion of the basic and most common principles within it, followed by an exploration of how just war thought can be applied to the war on drugs. The discussion and conclusions presented here will be further demonstrated by the empirical evidence presented in subsequent chapters.

\section{-- The Elements and History of Just War Theory --}

Amstutz (2005) identifies three main perspectives on the use of force: pacifism, amoral realism, and principled realism. Pacifism is against any force while amoral realism sees force as a perfectly utilitarian and legitimate means of achieving an end. Just war falls into the third category, principled realism, where force is politically and strategically necessary at times. Principled realism might also be called qualified realism, where one recognizes certain situations in which a resort to the use of force is necessary, but only within certain conditions. Just war tradition is based on the assumption that coercive power is legitimate when it serves a morally legitimate purpose, and that war "is not intrinsically evil but rather an instrument of statecraft" (Amstutz, 2005: 111). In order for a war to be just it must meet certain criteria ad bellum - the decision to go to war - and in bello - how a war is conducted once begun. Debate often centers on 
whether the guiding principles laid out by Roman law or the church, and thinkers such as Cicero, St. Augustine, and Grotius, historically have served to restrain actions in a war, or whether they have excused them instead (Kaufman, 2005; McMahan, 2005).

While just war thinking has a long history of association with the Catholic Church, it is not solely a product of Christianity. Christopher (2004) shows evidence of similar prescriptions among several ancient cultures, from Sun-Tzu in fifth-century China to the Aztecs and others, even if some of the specifics do not resemble what has become modern just war theory. In Hebrew scripture, for example, one finds the idea that holding god's favor is an asset in war. It also lists conditions for keeping god's favor while fighting a war. These include many prohibitions against destruction of the environment more so than against destruction of other human beings. Temes (2003), Walzer (1996), Ravitzky (1996), Tibi (1996), and Hashmi (1996) have all written about Jewish and Islamic perspectives on war. An in-depth analysis of this body of literature, especially salient for wars in the Middle East or against terrorism, is beyond the scope of this project. Instead, I focus on the development of the western tradition since my interest is in the drug war in the Americas. Western and Catholic perspectives may also have particular relevance within the Latin American and Spanish Caribbean contexts.

Aristotle was the first to use the phrase "just war" but the precursor of present-day concept of just war ad bellum comes from Roman law and Cicero (Christopher, 2004). Under Roman law, a war could be formally just as long as certain procedures were followed in declaring it. Cicero articulated three conditions by which a war could be considered just: It had to be declared by a proper authority, the antagonist had to be notified, and the antagonist had to be given an opportunity to make a peaceful settlement 
before any attack could be made. Additionally, only those who were officially active military professionals could participate.

Later, just war doctrine developed as a way to keep communal order and to protect the Holy Roman Empire from invasion. It was a method for answering questions about how a Christian empire, if pacifist, could still defend itself. The doctrine represented a synthesis or compromise between Christian and Roman values. St. Ambrose is an important name in the development of just war doctrine during this time. He thought that wrong behavior was not just doing harm, but also the failure to prevent another from inflicting harm. From this point of view, the use of force could extend from self-defense to the defense of others, including intervention in another's war or affairs. With these developments "the Roman legal notion of Just War [was] gradually replaced with a moral or religious notion where the forces of good combat the forces of evil" (Christopher, 2004: 23). Christian scripture is often a source of pacifism for some, but also contains justification of violence for others. The common example of this is the Crusades, but the theme of good versus evil also appears in the war on drugs.

St. Augustine, a student of Ambrose, wrote about the political duties of man based on his reading of Plato, Aristotle, and Cicero. In these writings he also achieved a synthesis of Roman and Christian values and may be called the "father of the modern Just War Tradition" (Christopher, 2004: 42). Augustine retained Roman principles of a just cause for war, a war declared and carried out by a proper authority, and argued that the final objective of any war is peace. He added that soldiers should never fight for fame or glory, or with a spirit of vengeance. 
St. Thomas Aquinas is another contributor to just war thought, who drew upon Aristotle and St. Augustine before him to develop the argument that right moral choices are based on reason. He reiterated the ideas that a just cause, proper authority, and right intention were all necessary for a war to be just. For him, just cause may or may not be an aggressive action to defend oneself against, but could be a fault of the other, such as not being Christian. An important element that Aquinas contributes is the notion of proportionality in the conduct of war. The discussion of proportionality includes what is called the double-effect. An action may have a good intended effect, such as saving one's own life, but also have a bad unintended effect, such as the death of the aggressor. Aquinas saw the negative effect as permissible as long as it was not out of proportion to the good effect. Fifteenth century Spanish philosopher Francisco de Vittoria expanded double-effect to include collateral damage in war. While de Vittoria argued that not providing protection for those not directly involved in the fighting would be contrary to natural law, he nonetheless recognized that through the application of double-effect, innocents often would be harmed during the conduct of a just war. He is credited as the first to make a statement about "military necessity" to excuse foreseeable harm to innocents (Christopher, 2004: 56). This notion of the double-effect could easily be invoked to excuse a variety of NUCs in the war o $\mathrm{n}$ drugs.

The themes of legitimate authority, just cause, and proportion are all of particular interest in relation to the war on drugs, all themes within international law surrounding wars. Sixteenth-century philosopher Hugo Grotius is credited as the father of international law (Christopher, 2004). He lived and wrote during a time of decline in central church authority. This decline made the use of force the more "common medium 
of political discourse" (ibid.: 67). Grotius believed in the social nature of man and that life in society was more important than individual self-preservation. For him "neither persons nor states have an absolute right to self-defense" (ibid.: 69). At the same time, Grotius argued that wrongdoers could be punished by force and that civil authorities had an obligation to do so.

Grotius recognized six conditions for just war ad bellum: 1) just cause, 2) proportionality, 3) reasonable chance of success, 4) public declaration, 5) legitimate authority, and 6) war as a last resort. On number three, he said that fighting for freedom was fine but suicidal resistance is wrong, because life is of more value than liberty. Grotius omitted two conditions that others had included prior: right intention, and that the war be fought justly. For him, the first was not an objective criterion about a relation between states but an internal assessment of one. Each side can easily think it has the right intention in war. The second applies to jus in bello, which Grotius treated as distinct.

The main in bello principle for Grotius, as described by Christopher (2004) is that the "prohibition against intentionally harming other human beings is set aside in warfare only to the extent that combatants of opposing belligerent nations may rightfully attack one another" (91). Large groups of people then have immunity from attack, but like de Vittoria, Grotius recognized that they might still be harmed and adopted a version of Aquinas's double-effect "with precautions" (ibid.: 92). Gotius said that there must not be intentional or foreseeable harm to innocents.

Grotius was interested in how to fight, expanding on Aquinas's interest in when to do so. Grotius's innovations "gave a voice to the secular experience of moral thought" 
(Temes, 2003: 48). They have allowed statesmen to make policy decent without having to follow the orthodoxy of any particular church or religion. During the period of Enlightenment thinking more emphasis came to be placed on the individual. This represented a major break with the church of the middle ages and the kind of just war thought we saw from Augustine and Aquinas. The state comes to be thought of as the representative of the individual and the defender of individual rights.

Temes (2003) suggests that just war thought in the transition from Grotius's time to the present has been taken up by many different philosophers from Rousseau to Locke, Kant, and Jefferson, even if it was not called just war theory explicitly. Their ideas about natural law differ from those of Cicero or Aquinas, and their writings tend to look at the nature of man, society, and states more than warfare specifically. During the same period the Catholic Church retained a philosophy about just wars. Later, the United Nations created numerous documents that address war, the conduct of war, and the treatment of people involved in war, including the U.N. Charter and the Geneva Conventions.

Temes lays out three basic principles for a just war which resemble many of the principles embodied in the Geneva Conventions and the U.N. Declaration of Human Rights: 1) a just war sanctifies human life and treats all life as equally precious, 2) a just war is a war about the future, not the past, and 3) a just war preserves and strengthens the principles of individual rights, based on the notion that the legitimacy of government derives from the consent of the governed (193). The third principle also applies to jus post bello, which is not discussed extensively here, nor in much of the early literature on just wars. Thinking about how a state should act in the aftermath of a war is important if peace is to be maintained. It also informs the way criminals or the prisoners of war are 
processed and treated in the war on drugs. Temes three principles can be used to measure the justice and evaluate the conduct of the war on drugs in the Caribbean.

\section{-- Just War in Global Context --}

Frequently, international agreements are based on expediency and consensus rather than on moral principles. Realism is dominant in the study of International Relations, it does not deny international ethics but it also does not allow much room for moral reasoning. Amstutz (2005) argues that there is no need to separate moral reasoning from policy as foreign policy making usually involves some kind of moral judgment. The just war tradition is one example of the attempt to establish and clarify universal morals or shared international ethics, especially questions about the ethics of the use of force.

"Attempts to develop a system of international law to regulate the use of force have largely been an effort to codify the tenets of Just War Tradition" (Christopher, 2004: 2). Ideally, the social setting of the international society of states means that all are obligated to participate in agreements made among them, and no one can change agreements without the consent of the others. ${ }^{1}$ The sets of norms, customs, codes, principles, legal precepts, international agreements, and so on, form what Walzer (1977) calls the war convention. It must be remembered, though, that this convention does not rest on any central judicial system or authority. The common law of warfare may always be changing, and punishment for supposed violations difficult to enforce.

\footnotetext{
${ }^{1}$ Of course there are always exceptions allowed by international law, such as modifications or side agreements between states.
} 
Temes argues that war is less about what is ultimately right and more about what the best options are at hand. The ideals for which wars are now fought are different from ancient and even slightly more recent wars fought for honor (of the individual or the tribe) or for plunder and conquest (material gain). These motives for war are now seen as wrong; wars of aggression and those fought for glory, revenge, or conquest are explicitly condemned by just war doctrine and international law. And yet these reasons are concrete. A soldier might find a more solid connection to fighting to prove his or her own valor and strength, or to gain something of tangible value for the nation, than to abstract ideals of justice or democracy.

Modern wars are frequently fought over abstract ideals. Amstutz (2005) claims that just war theory "provides a framework for defining and assessing the use of force" which in turn allows for limiting the possibility of war or the destructiveness of it in the pursuit of these ideals (111). He continues, arguing that "the aim of the theory is not to justify war but to bring international relations under the control of morality so that, if moral norms were followed faithfully and consistently by the disputing parties, it would reduce the risk of war" (ibid.). Similarly, Temes (2003) suggests that Kant placed an emphasis on restraint and respect for enemies in war, and that his ideas were less about making peace than about living with others. A state has a right to defend itself but all states should be more concerned about maintaining an international community and a just peace. Unfortunately, Kant is unable to say how such an ideal state of affairs can be achieved, and gives "no real answers beyond the dream of world government" (Temes, 2003: 52). Some may even say the notion of a universal governing body or set of norms is naïve and unrealistic. The world is comprised of nations and groups of people with 
some similar, but also widely different values. The solution to ending the war on drugs by learning to respect and share the world community with transnational criminal organizations is not likely to be adopted by the U.S. or any other state. Likewise, fighting a war to create or support democracy appears contradictory as militaries are among the least democratic entities within a state. At the same time, Temes argues that the value of Kant's philosophy is the similarity he sees between individuals and states. It is supposed to make us remember to be humane when moving to the larger scale of modern warfare between states and other group entities, as each is comprised of many individuals with rights.

Given this context, the next section looks at how the principles of just war can be applied to the war on drugs. The question is not an easy one for several reasons. In addition to the international nature of the drug trade, the difficulty of coordinating efforts to control it, and an absence of concrete universal attitudes toward it, there is the difficulty of defining actions against drugs as actual war. I argue that calling it a war is powerful - and may have serious consequences for the way law enforcement is handled.

\section{-- Applying Just War Thought to the War on Drugs --}

"The morality of a nation will be revealed by how and when it fights wars," and yet the war on drugs is difficult to classify as a type of war (Temes, 2003: 4). It is not aggressive but it could be seen as preemptive or a form of intervention. Just war theory ad bellum considers the decision to go to war. In the case of the war on drugs the required legitimate authority has made the decision, at least for the United States within its own borders. For the most part, the Dominican government is also a legitimate 
authority that can choose to participate in the same war. The extent of drug traffic through the Dominican Republic and pressures from the U.S. government to stop it mean that the Dominican government's choice was already made for it to some extent. Legitimate authority or not, choosing to opt out of the war completely would be bad policy for the Dominican Republic domestically as well as internationally.

One problem with applying just war thought ad bellum to the war on drugs is that one side is a state and purports to follow legal and moral guidelines, while the other is an amorphous entity or organization and does not adhere to any generally accepted protocols or international agreements. The "other" can more easily be seen as cold-blooded killers than as fellow soldiers or comrades at arms. It may be easier to move away from moral considerations when not fighting another professional army, and to see them as less than human and less deserving of humane treatment before the law. It is also easy to use St. Thomas Aquinas' assertion that a just cause for war may be a fault of the other - if it was right to declare war on non-Christians to civilize them in his time then it is right to declare war on those who have little regard for the law and cause harm to the extent that drug traffickers do.

Just war theory tells us war must have a good purpose and a right intention. There can be little doubt that eliminating the violence associated with the drug trade is a worthy goal, and the intent behind counter-narcotics efforts is to eliminate the illicit activity. But a good purpose and a right intention do not ensure a successful war. Many counter-narcotics efforts to date have had little effect. Officials estimate that only about $10 \%$ of all the drugs coming into the U.S. are apprehended, and what does come in is cheaper and stronger (Falco, 1996; Nordstrom, 2007; Youngers \& Rosin, 2005). 
Dominican newspapers report the beatings and deaths of suspected drug dealers by police (see for example Rodriguez, 2007). In a study of Puerto Rican housing projects, Beruff (2000) found that five years after National Guard troops were brought in to control drug violence the problem had actually gotten worse - and had spread to other neighborhoods where it had not existed before.

In "Politics and the English Language", George Orwell (1946) argues that political speech and writing is particularly adept at defending the indefensible. Calling the war on drugs a 'war' attempts to justify stronger actions and the use of more deadly force than is tolerated for other law enforcement issues. Calling it a war is a simplification and a kind of propaganda: "The act of representing the complexity of the world in simple terms for the sake of a political end" (Temes, 2003: 151). Few have backed away from the war on drugs since it was declared. The language of evil and greed is powerful for garnering support for the policy, and few want to risk their reputations in office by being thought of as on the side of the criminals.

Anti-drug policy is attractive in the form of a war. It fits neatly and conveniently with many people's conceptualization of drugs as foreign and bad, an external threat to our internal order. Internal demand for drugs is produced by an external parasite beyond our borders. Military protection is seen as a better answer to the threat than anything more inward looking like treatment or decriminalization. As Falco (1996) pointed out, "blaming foreigners for America's recurring drug epidemics provides convenient if distant targets for public anger that might otherwise be directed toward elected officials" (121). The outward policy also fits neatly into the pattern of American exceptionalism 
and righteous benevolence that has characterized U.S. foreign policy for much of its history, especially in Latin America.

Further, the notion of a just war also "hints at the tactical advantages of having God on one's side" (Temes, 2003: 4). This might seem less complicated in a war on drugs and crime where right and wrong may be more clear-cut than against terror or competing religious ideologies. Still, drug traffic has been conceptualized as an embodiment of evil in much the same way other enemies have been, and the rhetoric of righteousness reinforces that imagery, inflames sentiments, and reduces the criminal to something less than human. "A Just War acknowledges the humanity of all parties, including enemy combatants" (ibid.: 154). This statement, though, is the opposite of the simplifications discussed above that reduce the other to something evil and less than human, which makes it easier to fight with a spirit of vengeance in spite of St. Augustine's warning against such a practice. It may also expose a contradiction between jus ad bello and jus in bello in the war on drugs. How can we effectively fight this evil, and yet still treat it humanely?

Just war theory in bello deals with the conduct of the war once it is underway. Proportion is a key principle. The means and costs of conducting the war should be proportional to its end goal and purpose. Some may argue that the war on drugs should be waged no matter what the cost; others will say the costs are too high considering the results so far. In the early 1990s the annual pentagon budget for drug interdiction was more than one billion dollars (Morrison, 1992). Between 1997 and 2002, U.S. military and police aid to Latin America and the Caribbean for counterdrug programs totaled 2,737 million dollars. In 2006, the U.S. spent close to 430 million dollars on counter- 
drug assistance in the Americas over and above money spent on interdiction efforts on the home front (Isacson, 2005; Center for International Policy, 2007). The DEA made just under domestic 30,000 arrests that same year (U.S. Department of Justice, 2007). The U.S. government continues to spend money to fight drugs yet they continue to be readily available.

Proportion does not apply only to the money spent on the war. When it comes to utility and proportionality, "the rules of war rule out only purposeless or wanton violence" (Walzer, 1977: 129). Actions that are conducive to victory can be justified this way and frequently are. The problem then is that victory is more valued than individuals or collective interests. Limits to behavior beyond mere utility should be accepted not just because they are useful but because they are "morally plausible to large numbers of men and women" (ibid.: 133). In other words, there is some kind of theory of rights or a democratic norm for what is permissible in war, and thus "a legitimate act of war is one that does not violate the rights of the people against whom it is directed" (ibid.: 135). Even criminals and the worst drug traffickers have rights and should be treated by the rule of law, especially in a democracy.

Following this logic, the war convention applies to aggressors as well as defenders, yet the drug war is against those who are outside the law. At times it is difficult to know who the aggressor is. Is the U.S. an aggressor by declaring the war in the first place? If the U.S. and its allies in the war are the defenders, they may be putting themselves at a disadvantage by adhering to the convention. When warriors within governments and police or military forces are corrupted by drug money the problem is worsened. One might wonder whether the war on drugs can only succeed as a dirty war, 
fighting fire with fire and lawlessness. The danger is that a temporary suspension of norms in this war could become the usual state of affairs as it drags on. The safeguards for distinguishing the guilty from the innocent are lost. The war convention prohibits attacks on non-combatants, but who they are in the war on drugs is still not entirely clear.

Another principle of Just War in bello is that of necessity:

War is a world apart, where life itself is at stake, where human nature is reduced to its elemental forms, where self-interest and necessity prevail. Here men and women do what they must to save themselves and their communities, and morality and law have no place (Walzer, 1977: 3).

Is or should the war on drugs be the same? The violence of drugs is certainly a threat to life and community, but we must ask if all is fair in fighting it. The problem of drugs is large and traffickers often have more money and better technology than those who are trying to control them, at least as far as we can estimate (Griffith, 1997; Griffin, 2000; Nordstrom, 2007). Is it necessary to escalate efforts to track down and stop drug traffic? Is the problem so bad that individuals and our communities' very existence are at stake and we have to do anything to save ourselves? If morality and law have no place and there is a loss to individuals, will it be a necessary but temporary sacrifice?

The caveats of military necessity make distinguishing between legal and illegal actions in war and punishing war crimes difficult or even impossible. "Military necessity amounts to a claim that certain blatantly immoral acts are justified on no other basis than that they might contribute in some way to military objectives" (Christopher, 2004: 150). Even when tactical, strategic, or political objectives are specified, generally no distinctions are made for military necessity. If "almost any action imaginable might on some occasion be lawful based on military necessity" then it is "virtually impossible for 
soldiers to know with any surety whether certain orders they might receive are lawful or not" (ibid.: 150). Imagine then how much more ambiguous the distinction becomes when one is involved in a pseudo-war. The confusion is even greater where the line between military objectives and standard law enforcement is blurred.

"The moral equality of the battlefield distinguishes combat from domestic crimes" and thus soldiers are not considered murderers when they kill one another (Walzer, 1977: 128). But the war on drugs does not take place on a battlefield. The drug trade is both international and domestic crime. One must look at when or if police and military forces are allowed to treat traffickers as enemy combatants. One could ask if the same methods or rules apply to large- and small-scale dealers or drug users. Lastly, one must consider how many people can be killed in the course of making arrests and still be justified in the name of this war. By calling it a war, one wonders how much loss of due process is expected to be tolerated, how much will be tolerated, and how much might never be regained.

At the time that St. Augustine and Thomas Aquinas were writing about just wars, war was conceived of as the pursuit of peace in the larger context of Christianity. Now we are not necessarily looking for ways "to apply moral principles without having to accept larger philosophical or religious systems" but "to see the wars of our time as clearly as possible and with full advantage of all available moral perspectives on them" (Temes, 2003: 14). This pursuit may be more difficult when individual leaders are particularly devout, be it President George W. Bush or the officially Catholic government and state of the Dominican Republic. Temes refers to the United States as "a nominally non-sectarian world power with a mildly Christian bent" (16). Using the phrase "armed 
moralist" he talks about both presidents Wilson and GW Bush who use the language of principles and philosophy to justify actions in war. Both emphasized freedom and democracy - fighting to make the world safe for democracy, or fighting against evil to spread democracy - which are abstract things to fight and die for. Stopping drug traffic has become a higher priority than the commitment to the spread of democracy. One has displaced the other while failing to recognize the links between the two.

\section{-- Some Preliminary Conclusions --}

Just war theory is of a "presumptive conservative character" (Amstutz, 2005:

112). Jus ad bello principles tend to preserve the status quo, especially in relation to a legitimate authority and just cause. The drug war is declared by the established state authority and the 'enemy' is not really an entity vying to gain control of the government or territory, other than to buy off that government so that its operations may continue. Still, the current approach to fighting drugs rarely addresses new or radically different approaches to the problem. Policy makers in the U.S. are more likely to impose U.S.style thinking about the drug war on its 'allies' in the war than to consider or adopt any of their homegrown approaches, and defending U.S. borders from drugs does not get rid of the drug problem as a whole. Extending the drug war beyond our borders and in to other states might even be considered aggression and a violation of sovereignty.

“A just war is one that it is morally urgent to win" (Walzer, 1977: 110). Few would deny that the threat from drugs is serious and must be addressed in some form and with some measure of success. "What is essential in war is victory, not prolonged operations" (Sun Tzu, as quoted in Christopher, 2004: 8). And yet "if it is sometimes 
urgent to win, it is not always clear what winning is" (Walzer, 1977: 110). Winning the war on drugs could mean a total destruction of the enemy, destruction of all drug production, traffic, and consumption; is that even possible? Unconditional surrender of cartels is highly unlikely, as are compromises or settlements with them. This is where other non-war approaches might help achieve the ends sought by the war. The theory of justice implies responsibility and accountability. States are responsible for upholding the rights of citizens even in the midst of the war on drugs. Officials are accountable to the people in a democracy, even one facing a crisis and especially where democracy is not long established.

"The absolute rejection of war means victory for forces that ought, on their merits, to be fought against" (Temes, 2003: 12). The choice is not always between right and wrong, but between wrong and more wrong. Jus ad bellum and jus in bello are treated separately and a war might satisfy the requirements of one but not the other. This is the case with the war on drugs. We can identify a just cause, where drugs cause harm to those who use them and the violence and corruption associated with the drug trade are rising. But for a war to be moral, it must fulfill both - and both the strategies and tactics in the war on drugs do not appear to do so.

\section{Changing Paradigms in IR and Definitions of Security}

Just War Doctrine is compatible with other theories of international relations, which also help to illuminate and explain the NUCs of certain policies. While this study assumes states are the primary actors in the way that a Realist perspective looks at external threats to state security and sovereignty, it also incorporates a Liberal 
perspective like that detailed by James Rosenau which assumes new actors and phenomena are changing international relations, and actions from one issue or policy area can have resonating or cascading effects elsewhere. The transnational drug trade has created turbulence in the world system because non-state entities are threats, and the definition of security has expanded to include more than the existence of the state itself. Security in the war on drugs has implications for individual citizens as well as for institutions within states.

It has become increasingly evident over time that threats from the drug war itself may be made to citizens and their civil rights. Recent literature that has addressed this issue has primarily focused on the main drug producing areas in the same way U.S. policy does. Much of the scholarship on drugs in the Caribbean at the close of the $20^{\text {th }}$ century emphasizes security, changing definitions of security, and the role of states. Security is expanded to include threats to the state from actors other than states in the international system. These threats may be to the existence of the state, or even to the environment, economy, social and cultural traditions, and particular institutions and individuals within the state.

Griffith's definition of security is based on Realist principles: Security means "protection and preservation of a people's freedom from external military attack and coercion, from internal subversion, and from the erosion of cherished political, economic, and social values" (1997: 5). He also recognizes that most states "exist with a certain margin of insecurity" (ibid.). I would add that some states have a larger margin of insecurity than others, and that some sectors within an individual state have a greater degree of insecurity than others - women, for example, may be more vulnerable to 
certain kinds of threats than are men (see Tickner, 1997). Other vulnerable groups may include the poor, ethnic or racial minority groups, and so on. For Rogers (1999) drugs are clearly a security issue beyond traditional Realism. He identifies three types of security: National defense, public security, and citizen security.

National defense or traditional security issues focus on the protection of sovereign borders against external threats, as well as defending values and interests. The threats need not come from another state. The Dominican Republic and the greater Caribbean have long been entangled in U.S. national defense issues. Public security involves the maintenance of public order and the enforcement of a nation's law. Drug trafficking and organized crime in the Dominican Republic and the United States have led to increased state activities to 'enforce' the law and stabilize public order. As a result, the missions of the military and police become blurred and state security institutions have become more repressive. Blurring the lines between national and public security also threatens citizen security, defined as protecting civil and political rights (Rogers, 1999: 55).

By framing it this way, threats to one type of security can then cross over into the areas of other kinds of security. As the definition of security broadens and threats become larger in number and more amorphous, the forces used to control them can be used for just about anything - or against anyone. As with just war theory, ever-changing definitions of security can either be used to constrain or justify actions or abuses of power.

The turn of the $21^{\text {st }}$ century marks a time where "changing paradigms... are altering the structures of world politics and adding new issues to the global agenda" (Aydinli and Rosenau, 2005: 1). The drug trade may not be entirely new but the context in which it operates has changed. "Among the central tasks of governance at all levels of community is that of achieving order over and across shifting, elusive, and often unrecognizable boundaries" (Rosenau, 1997: 8). The frontier is the area where the domestic and the international meet and interact. The frontier itself has grown - and 
grown in importance - for a variety of reasons, including a globalizing economy, the mobility of people and ideas, the end of the Cold War, and the rapid development of technology. The United States and the Dominican Republic are a good example of this history with many years of cultural exchange, occupation, migration, economic relations, and of course counter-drug policy and operations.

The difficulty of studying the interaction of international factors on domestic processes represents "one of the most deeply rooted paradigm divides in political science" - that is, the divide between international relations and comparative politics (Schmitter, 1996: 28). Clearly, "the international context is a notoriously difficult variable to pin down" and "its causal impact is often indirect" (ibid.). In a turbulent and interdependent world events and processes at one level do have influence and consequences at other levels. These are especially salient when goals are contradictory, when the hierarchy or mechanisms of control are unclear, and when the locations of authority overlap. In an interdependent world, "the need for control mechanisms outstrips the capacity or readiness of national governments to provide them" (Rosenau, 1997: 172). More specifically, the need to control a transnational issue as widespread and difficult as drug traffic outstrips the capacity of any one national government alone.

Rosenau also discusses macro-micro level interactions in world politics. Micro generally refers to citizens, officials, and leaders. Macro generally refers to states, transnational organizations, and collectivities such as national subgroups and 'publics'. Micro is not necessarily a particular unique individual but someone who is a part of "the network of systems in which he or she is embedded" (Rosenau, 1990: 117). In other words, it may make sense to examine specific leaders or actors but it can also be useful to 
include other individuals who make up the system or society, or at aggregate groups of individuals that are a part of that system. This argument supports the use of the public opinion data included in this dissertation. The effect of macro-level policy can be at midlevel, such as on a state judicial system, which in turn has effects at the micro level. These cascades are the sequences of developments from and through one level to the next, creating action, interaction, and alteration along the way. Public opinion data allows us to access and evaluate individual assessments, in the aggregate, of macro-level responses to the international and domestic effects of the drug problem.

Here is a brief illustration of cascading effects from one level to the next. At the micro level, one scientist isolated the active ingredient in coca leaves and cocaine was born. Over time individuals began using this substance and eventually a drug culture grew. This subgroup of users begat another group of suppliers which eventually grew into a macro-level business and transnational venture. Interaction continues between macro-level supply and mid-level demand. Negative effects are seen on individuals at the micro level. Demands for control come from all levels. Response in the form of laws and policy is at the macro level.

Other macro factors keep the drug trade going in addition to demand from users. Global economic conditions and markets make drugs profitable and attractive, yet macro policies in practice rarely address these other factors. Instead the policy of interdiction at the macro level is beginning to show other ramifications at the micro level. Individuals are affected by policies that infringe on their rights. The next wave from micro to macro may be a push for alternative policies, particularly from those in academic or humanitarian circles. 
Micro-macro interaction is less problematic for analysis to Rosenau than it is for some other scholars. Instead of seeing individual versus society or finding difficulty in drawing macro conclusions from micro observations, he sees an opportunity to look at "the ways in which large, impersonal forces at work in the world both derive from and influence the actions of people in coping with challenges and conducting their affairs" (Rosenau, 1990: 143). Analysis would be easier if one could treat micro and macro as separate and constant, but an interactive approach is more realistic and reflective of the way things actually work:

To proceed from the premise of interactive variability at both levels is to require concerns with leadership, followership, authority relations, aggregation, consensus formation, institution building, momentum, intergroup bargaining, and the many other sociopolitical mechanisms through which micro actions are converted into macro collectivities and policies (ibid.: 144).

In other words, the use of individual level data to evaluate state or international level policies is not erroneous or disingenuous because all levels are connected and influenced by one another in the real world. Macro-level policies affect citizens on an individual basis but aggregate data can demonstrate trends in the effects created by such policies. Rosenau's assertion is echoed by some within the democratization literature, and their contributions are also informative for this study.

\section{-- Democracy and the International-Domestic Nexus --}

Whitehead (1996) notes that when one reads a list of all countries considered democratic, nearly all of them became so because of some international factor such as decolonization or the end of the Cold War. He divides international influences on democratization into three categories: contagion, control, and consent. Contagion is 
more or less his term for the domino effect - if one country democratizes others are likely to follow suit. While this may be a possible explanation for waves of democracy, it is also a weak one, as many countries such as Cuba persist while others around them change regimes.

Control instead signifies a stronger influence from an external source. "Twothirds of the democracies existing in 1990 owed their origins, at least in part, to deliberate acts of imposition or intervention from without" (Whitehead, 1996: 9). Whitehead also asserts "that in almost all the democratizations that have occurred between the Second World War and the dismantling of the Warsaw Pact, the strategies of regulation and control adopted by the dominant states in the system were of critical importance" (ibid.: 15). The dismantling of the Warsaw Pact in 1991 was after the initial transition to democracy in the Dominican Republic in 1978 but prior to the complete transition in 1996, and so the critical importance of dominant states was probably still a key factor. The influence of the United States likely became stronger in the post-Cold War period and new era of globalization.

The third international dimension that Whitehead (1996) addresses is consent, which adds an internal element to the external influence of control, where "the actions and intentions of relevant domestic groupings, and the interactions between internal and international processes" create the push for democratization (15). Consent is Whitehead's version of what Rosenau calls linkage politics. This approach introduces much more complexity to the model, but again echoing Rosenau, it is a complexity that Whitehead argues is closer to reality. For him "a genuine and securely implanted democratic regime requires the positive support and involvement of a wide range of 
social and political groupings, support that must be sustained over a considerable period and in the face of diverse uncertainties" (ibid.). This argument seems logical enough - a change of regime, imposed from the outside or not, needs a certain amount of support from the bottom up if is to be real and lasting. As noted, to address this idea data on public opinion and support for the democratic government in the Dominican Republic will be examined at in more depth in subsequent chapters.

Democratization proceeds through stages in most cases, and may be quick at the beginning - the transition stage - and longer and more deliberate later on - the consolidation stage.

"From this staged or phased notion of regime change comes one of the most important hypotheses linking the international context to domestic political outcomes: regardless of the form...that it takes, external intervention will have a greater and more lasting effect upon the consolidation of democracy than on the transition to it" (Schmitter, 1996: 40).

Thus, the global economy or relations with a dominant power may be part of the reason the Dominican Republic ranks as low as it did within the IDD (Democratic Development Index - Latin America) for 2007, and even lower than in previous years. External priorities may not be allowing for improvements to internal factors most important to consolidation. Whitehead wonders:

if the United States has generally favoured democracy promotion for so long, and if US influence in the region has been so great, and if the underlying local realities have been relatively favourable - why then have the results been so slow, uneven, and modest? (ibid.: 62).

Dominican efforts to cope with the simultaneously internal and external strife caused by the war on drugs has detracted from other elements of is democratization. 


\section{Conclusions}

Studies that attempt to separate international and domestic politics are frequently artificial and less informative for the topics and issues they wish to address. The concept of cascading effects in world politics helps to illustrate the ways that actions in one arena can influence outcomes elsewhere. By this logic, it is not unreasonable to think U.S. policy and its influence over nations in the Caribbean has changed the course of domestic policies and bled into other areas of interest to scholars and leaders alike. The war on drugs is meant to support states and democratic governance, but the realities of its implementation are also not easily separated from the processes of consolidation.

The following chapters delve into the specifics of U.S. drug policy, Dominican drug laws and policy, the structure of the Dominican judicial system from the police force up, and the ways the military in both countries is being used to enforce the law. I also look at the challenges faced by the government in reforming and professionalizing these entities. This information is then analyzed alongside a variety of data from recent surveys within the Dominican Republic as well as internal reports and studies dealing with questions of institutional effectiveness and citizen rights and security to show how the drug trade and influence of the U.S. have converged upon the Dominican Republic's unfolding democratic consolidation. 


\section{IV: Modern Drug Policy in Historical Context}

In this chapter, I begin with the history of coca in the western world, and the use of drugs and efforts to control them, an impetus primarily originating in the United States. This history provides a context for how coca has been perceived by people and authorities over time, and how drug control regimes have developed. Next I examine the International Narcotics Control Strategy Report issued by the U.S. State Department evaluating the record and progress of the contemporary war on drugs. Understanding the ways drugs have been treated historically allows us to see other possible ways of approaching their control and to again ask whether war is a justifiable solution to the problems associated with the illegal trade.

\section{Drugs in the Americas - A brief history}

\section{-- History of Coca: The Colonial Period --}

The Spanish conquest of the Andes initiated a discovery of coca and the transformation of its position and esteem within the region and eventually throughout the world. The debate over the benefits or evils of coca began early and continues today. In this section, I will show how the attitude of the early Spanish state and their subsequent use and treatment of coca changed both the attitudes and habits of the native population. These changes begun hundreds of years ago have contributed to the coca problem of the last century. The origin and development of the controversy has in part caused a rigid polarization in the current treatment of the plant and the perceptions of its use and potential. The attitude and position of U.S. officials toward the plant and its derivatives 
has changed over time. This unknown or frequently forgotten history provides a broader perspective on how just or balanced today's policies and perceptions are.

The native peoples of the Andes have used coca leaves in various ways throughout history. Evidence of this exists in the depiction of coca leaves and coca chewing in temple decorations, pottery, and textiles found at archeological sites (Gagliano, 1994; Mortimer, 1901). Cloth pouches and mummies containing leaves have also been found. The effects of coca on hunger, its use to sustain energy, and its use in medicine were what gave coca its position of importance among the Andeans. Coca was not just a stimulant used by the Indians for sustenance during times of food shortages or hard labor. Its many religious, social, cultural, political, and economic uses increased its intrinsic value (Meruvia Balderrama, 2000). The Indians did not worship coca per se, though it was revered and respected for all its powers. The best coca was offered to the gods and the Incas, while the rest was distributed to and used by the general populace.

The value of coca to the Incas and the Andean people was obvious to the Spanish upon their arrival in the New World. Accounts of the extent of coca use by the native population vary amongst the Spaniards who wrote on the subject during the colonial period, depending on their view of the 'habit.' Pedro Cieza de León "attributed the popularity of coca among the natives of Peru to be the result of an ill habit, as he put it, 'and fit for such people as they are"” (Inciardi, 2008: 116). From early on, Europeans associated coca with a lower class of people and lesser beings. In spite of this association, the economic value of coca did not escape Spanish attention, and it soon became evident that coca was not something they could ignore. Most noted the significance of coca, which was held in higher esteem than any precious metals (Meruvia 
Balderrama, 2000; Sánchez, 1997). A lucrative coca commerce was begun by the conquistadors in response to demand by the Indians (de la Peña Begué, 1971; Gagliano, 1994). "Their demand for the leaf became evident to the Spanish during the early years of the conquest as the Inca agrarian economy collapsed and food scarcities spread" (Gagliano, 1994: 165). The plant was soon regarded as a miracle "whose leaves would enable the subjected natives to cope with their nutritional privations while providing them with the stamina to work in the mines" (ibid.: 33). Without scientific knowledge of any possible ill effects of long-term coca use, many believed the leaf to be an adequate substitute for food and rest.

Soon coca use was inextricable from colonial mining production. This is a period referred to by Gagliano as the institutionalization of coca use. Mine owners and operators provided their work force with a daily ration of coca leaves, as the Indians would refuse to work without it. Other entrepreneurs and landowners began to plant and grow coca to sell in the mining towns, especially Potosí (Gagliano, 1994; Meruvia Balderrama, 2000). The coca commerce proved to be highly profitable and grew as mining expanded (Gagliano, 1994; Sánchez, 1997). Exact data from this period is difficult to obtain according to these writers, yet they still find a correlation between the consumption of coca and the growth of the mining industry, even as the native population began to decline.

The view of coca as an exploitable commodity is an important departure from its traditional usage among the natives during the time period. In purely economic terms, coca had many allies among the Spanish, but it had just as many opponents. Some officials from the church complained that the use of coca inhibited their efforts to 
Christianize the natives, calling it "the single most important cause for the persistence of idolatry" (Gagliano, 1994: 48). Others felt that its presence in indigenous customs proved its connection to the devil, and a lack of knowledge of the stimulants in coca led many to believe the supposed effects felt by the chewers were superstition, both proof of the devil's work and of coca’s danger (de la Peña Begué, 1971; Gagliano, 1994; Sánchez, 1997).

Other prohibitionists cited the cruel and harsh conditions Indian laborers were subjected to on the coca plantations in the eastern territories (Gagliano, 1994). The best coca growing regions were found in the lower altitudes of the east where the weather was wetter and more humid. Indian mita labor forces were imported to the plantations to pick, dry, and transport coca. Many became ill or died from strange tropical diseases, collectively called el mal de los andes, which were exacerbated by the damp conditions and the way the Indians were often forced to work long hours in the same wet clothes (Gagliano, 1994; Mortimer, 1901). Mitas that had to travel long distances in their work are said to have suffered from the effects of altitude sicknesses during transport because of the severe altitudinal and climatic changes from the east to the sierra and mining regions.

By the time of Toledo, enough opposition had been voiced to warrant the implementation of regulations over all aspects of the coca commerce (Gagliano, 1994; Sánchez, 1997). The official policy was one of toleration; the consumption of coca was "un mal necesario" (Sánchez, 1997: 143). The 'habit' of coca chewing was associated with the natives of the sierra and was therefore considered primitive and vulgar by the 
Spanish, especially in the coastal regions (Gagliano, 1994). "It was presumed there could be no good custom followed by the Indians" (Mortimer, 1901: 149).

One effect of the policy of toleration, combined with scorn from the civilized settlers, was that while workers in the mines could still have coca, its use was to be dissociated from all religious, medicinal, or superstitious meaning or context (Gagliano, 1994; Sánchez, 1997). Documents from the Inquisition refer to the use of coca in nearly every case (Gagliano, 1994). To chew coca outside of the mines, or to use it in any ceremonial fashion, was to subject oneself to punishment under the law (Sánchez, 1997). Essentially, the law was secularizing coca (Saignes, 1988). It was no longer valuable in any function other than as relief from harsh labor. What had once been a support in times of scarcity had become a requirement in a life of drudgery, doled out by an uncaring boss, and completely devoid of a connection to the divine, metaphysical, or spiritual.

The contradictory attitude of the state, combined with its return of the leaf to the reach of all, especially the humblest in society, is the source of the coca's loss of esteem (Saignes, 1988). Saignes also argues that the rise in consumption of the leaf after the conquest is evidence of a euphoria over something readily available that had long been prohibited for the masses. This argument, combined with Meruvia Balderrama's assessment that subsequent generations of coca chewers had different perceptions of the leaf, should lead us to understand that the position of the leaf within Andean society was indeed changing.

As early as the $1600 \mathrm{~s}$, there is evidence that in spite of a general attitude of disdain for coca, some Spaniards and mestizos were trying it themselves (Gagliano, 1994; Sánchez, 1997). The first non-Indians to use coca were in the sierra, but later others in 
the coastal region and in Lima were using it. The people in the sierra claimed it helped them adjust to the altitude and the climate, while those in the city espoused its medicinal applications for a wide variety of ailments (Gagliano, 1994). There came to be nearly as many laws and writings on coca as there were for the mining industry - most against consumption but very few against traffic (de la Peña Begué, 1971; Meruvia Balderrama, 2000). The result was punishment for the Indian who bought coca and few consequences for the Spaniard in charge of its transport (Sánchez, 1997).

Little use for coca outside the New World was seen until the 19th century and the isolation of cocaine from coca (Gagliano, 1994). Baldomero Caceres (1978) believes that since then coca has been pigeonholed, just as Mortimer wrote more than 70 years before him. The world's perception of coca is often the same as that of cocaine. Both authors, and others like Gootenberg (2008), have argued and emphasize the point that the two are different and separate entities. The "idea of a single active principle which should represent the potency of the leaf" is a false assumption according to Mortimer, and "the qualities of coca are not fully represented by any one of its alkaloids thus far isolated" (1901: 183). He felt that much more research on the plant was needed before it should be outlawed or discarded outright. Caceres feels the same way but supports his argument from a cultural perspective as well as a scientific one. He says the whole of Andean society and the whole of the plant are being condemned for what one substance in isolation does to some people in some circumstances, and that research thus far has been biased against finding positive effects.

In contrast to the colonial period, the anti-coca campaign of the 20th century has been more successful, though many of the same arguments are used. References to the 
"vice" and "superstition" of coca use are common (de la Peña Begué, 1971; Gagliano, 1994). Caceres argues that the supposed bad effects, such as illiteracy, that come from habitual coca use among Indians can be attributed to other socioeconomic factors. Indeed, as early prohibitionists often argued, the use of coca would be reduced or even unnecessary if the Indian had sufficient food and rest (Gagliano, 1994; de la Peña Begué, 1971). Coca alone cannot account for the continued marginalization and isolation of the indigenous population within the Andean nations, or the poor and the addicted anywhere in the global drug market. Caceres also finds a lack of correlation between the scourge of cocaine addiction in the developed world and the tradition of coca usage among the natives of the Andes. To equate the tradition with a sickness, as some in the counternarcotics movement have done, implies that the culture that would contain such a tradition is flawed. This same argument can be used to justify eradication efforts abroad as opposed to domestic efforts to reduce consumption.

The association of coca with the native and its subsequent loss of esteem other than as an economic entity have affected the way that the world views coca. The disposition of the scientific explorer of the 19th century further skewed the definition of coca by isolating its stimulative elements in a laboratory. One may argue that the gods never intended coca to be used in anything other than its natural state and those who use its extracts are doomed, but it is those who have the most power on earth who make the decisions. The European conquerors set a precedent that has been followed ever since. The native use of the leaf has been subjugated and it now exists as an organic source for a chemical evil. As in the 1500 s coca is far too profitable in its illicit context to think that 
its cultivation in South America will ever be totally eliminated. "It will never cease to be valuable" (Cieza de León, quoted in Mortimer, 1901: 151).

\section{- Coca in the $19^{\text {th }} \& 20^{\text {th }}$ Centuries: Miracle Drug and National Commodity --}

The history of cocaine is most frequently told from the U.S. or European perspective, as a tale of the discovery, wonder, and danger associated with the drug. But its $19^{\text {th }}$ and $20^{\text {th }}$ century history is also a time of rebirth for Peru, with cocaine as a classic export commodity and mass consumption good that brought remote tropical areas into the world economy. Indeed, "Peruvians celebrated cocaine as a national fusion of timehonored Andean traditions (Indian coca) with modern elite science, industrialization, and profit" (Gootenberg, 2008: 56).

Drugs, along with petroleum, arms, and tourism, have modern histories as the most global and profitable of trades. Unlike other new colonial stimulants such as tobacco, coffee, rum, chocolate, or opium, coca was not immediately or as easily assimilated and consumed by Europeans, medically or otherwise. Coca became a regional commodity, and was linked to the success of silver mining, but it was not until much later as an illicit commodity that it gained the same level as a major consumption good. While there was some debate over its use by the natives during the late colonial period, there were few European supporters overall. Coca was not creolized or mestizoized in the way cacao had been, and it soon became a "marker of a degraded subaltern 'Indian' caste" (Gootenberg, 2008: 20). On a more practical side, coca leaf simply did not travel well in the way that tobacco, chocolate, and opium did. Most coca leaf that was shipped to Europe for refining arrived in an unusable state. 
The Enlightenment scientists of the $18^{\text {th }}$ and $19^{\text {th }}$ centuries brought about a renewed interest in coca, and made efforts to find the active principle of the leaf. The pace of industrialization and modernization of Western culture in the mid- $19^{\text {th }}$ century made for a "ready arena for the arrival of a new, miraculous energy-enhancing stimulant. Coffee, tea, sugar, and tobacco were already domesticated and too tame" (Gootenberg, 2008: 22). Most of cocaine's researchers were Germans, who were already dominant in the fields of chemistry, pharmacology, and so on, but there many others, including some Peruvians and perhaps most famously the Austrian Sigmund Freud. During the mid1880 s, these same scientists were testing possible uses for cocaine, often on themselves. Their applications included treatment for labor pains, hysteria, cholera, asthma, syphilis, and addictions to alcohol or morphine. A colleague of Freud's, Karl Köller, is most often credited as the first to recognize cocaine's value as an anesthetic. These various applications of cocaine in medicine fueled demand for the drug and for its use in research, thereby increasing its value and creating "an essential high-value commodity" (ibid.: 24). Franco-Peruvian pharmacist Alfredo Bignon, also a contemporary of Freud, created a simple method for making cocaine at home; that is, in the same place as coca's cultivation. This was one of many experiments designed to help Peru meet rising world demand for cocaine in the late $19^{\text {th }}$ century.

The wealth of cocaine and coca related research done in Peru during the same era is frequently left out of history, in spite of its "nationalist and commercial overtones" (Gootenberg, 2008: 37). In other words, coca was being re-imagined as a Peruvian product like quinine or guano before it. Its potential and association with the indigenous were both being reconsidered. Bignon's new faster and cheaper extraction method using 
kerosene and soda ash produced crude cocaine that was then exported and refined into cocaine hydrochloride by pharmaceutical companies primarily in Germany. Crude cocaine was considered a national product and part of an effort to produce more in order to satisfy world demand. By the last decades of the $19^{\text {th }}$ century, coca (and crude cocaine) was also seen as "an ideal good for a national conquest of the vast Peruvian Amazon" (ibid.: 53). Efforts to expand formal cultivation into the east were a sort of manifest destiny for coastal elites, as well as the "great white hope of government export policy" (ibid.).

In the 1880s, European pharmaceuticals such as Merck that were trying to meet demand for medicinal cocaine found Peru's crude cocaine a solution to scarcity. It was easier and better to import than coca leaf itself because it retained its full potency during shipping. By 1900 the U.S. was importing both crude cocaine and coca leaf for medical use and the manufacture of patent medicines. The U.S. became the number one consumer of cocaine and coca leaf products during that era, and one-third of all cocaine, approximately five to nine tons per year between 1900 and 1910, was made in the U.S. (Gootenberg, 2008). These booms in the U.S. and Europe would not have been possible without "a dynamic response by Andeans" (ibid.: 63). From the work of planters and peasants to pharmacy and factory entrepreneurs alike, "crude cocaine was Peru's fastestgrowing quantum export of the 1890 s" rising $600 \%$ from 1890 to 10,700 kilos in 1901 (ibid.). While coca and cocaine did not represent a major portion of Peru's exports overall, it was vital to certain regions within the country, the town of Huánuco in the Huallaga valley in particular. Peru also became an important part of global drug production as crude cocaine processing centers were established in Lima. 
Competition in Peru's cocaine business increased as more pharmacists and pharmacies, Germans and other foreign nationals included, began to use Bignon's technique. Smaller batches were thought to retain more active alkaloids and a cottage industry expanded into other areas, especially to territories deeper in the Andes and nearer the supply of leaf. These are many of the same areas where production reemerged in the 1960s and 1970s and continues today.

Processing also grew outside of Peru - U.S. and European pharmaceuticals used Bignon's technique - and the U.S. and others explored the possibility of creating their own coca cultivation. Most remained in Peru through the early 1900s, but coca leaf was grown as far away as Japan and India. Huánuco remained the "world capital of Peru's legal cocaine industry" (Gootenberg, 2008: 83). Drug production remained viable in the Amazonian region, but political developments as well as the loss of cocaine's prestige soon left Huánuco vulnerable. The year 1915 was truly the end of "Peru's boom in legal cocaine" which left "a struggling regional culture" (ibid.: 100). By the 1920s, crude cocaine was fully prohibited by U.S. law. Cocaine's use and production was subject to debate within Peru and was the subject of rising controversy internationally from the 1920s through the 1940s. Despite prohibitions, cocaine chains did not disappear but became more tightly controlled within the U.S.-Andean link by corporate (i.e., Coca Cola) and government entities, though Peru maintained some ties to both Dutch and Japanese chains.

World wide prices for coca and cocaine began to drop, and the crop became significant only in regional terms. National hopes for global profits from a national product were lost in Peru, and the market then was re-concentrated on traditional local 
users. At the same time, international anti-cocaine sentiment began to revive the idea of coca as backward and detrimental to national development, and to reassert racism directed toward its indigenous users. Ironically, cocaine was still considered by many to be a modern Western good and "Peruvian officials ignored pressures from the United States and the League [of Nations] to restrict cocaine and coca after 1920" (Gootenberg, 2008: 136). Peruvian officials thought global anti-drug efforts were discriminatory, especially as coca was still central to Huánuco's economy. They saw that coca supply did not cause a rise in the number of so-called fiends in the West; rather, restrictions on coca hurt national interests in Peru, causing surplus leaf and increasing the maligned Indian coca habit. Quotas on exports oppressed natives and others in the producing areas. As coca's prestige continued to decline during the interwar era, several scientists, agronomists, and coca specialists maintained their faith in the crop and worked to find ways to produce higher yields and better technology for drying and processing the leaf in order to compete with Asian producers. German pharmaceuticals maintained a monopoly on the refining of crude cocaine into cocaine hydrochloride, while the U.S. prohibited imports of all cocaine through the 1922 Jones-Miller Act. Despite smaller levels of production, cocaine remained somewhat profitable. The problem for Peruvian producers was there were no new markets in which to sell. "The size of the consuming market was governed by encircling restrictions rather than by relative prices or cost factors in making cocaine" (Gootenberg, 2008: 161). Some of Peru's cocaine industry supporters saw world drug regimes and conventions as "forums for industrial nations to protect their own national manufacturing interests" at a cost to those nations who wished to develop their 
own (ibid.: 169). The signing of drug treaties by Andean officials would imperil a national crop.

In the 1920s, Peruvian reports framed cocaine not as an abusable or contraband drug (in spite of its reputation as such in places outside of Peru) and advocated drug education over policing or punitive approaches. All controls were decided and implemented at the local level, despite the preferences of the U.S. or the League. While there was no overarching state control of the Peruvian coca and cocaine industry, authorities did begin some regulation of it related to sanitation or in the form of taxation after 1920. They had some concern with contraband in remote areas of the territory a decade later, though still not in a criminal or policing sense.

World War II expanded and militarized Peruvian state functions and increased the U.S. presence in its operations. This brought with it a rising concern with contraband, especially as Peru appeared to be tempted to sell cocaine to the Axis powers, formerly their best markets. Both Peru and the U.S. began to monitor these "suspicious" sales to Europe or South America within the still-legal cocaine industry. Licenses for refining cocaine, previously issued by the state and the Bureau of Public Health (BPH) in Peru, were suspended in 1939, and in 1941 the state issued its first anti-narcotics policing decree (Gootenberg, 2008). This meant the police and the BPH were "mandated to investigate all instances of illegal drug use or sale" (ibid.: 180). Legal cocaine did still exist, though Gootenberg suggests WWII was its point of no return. The war cut off access to the last markets in Germany and Japan, and competing circuits were effectively destroyed and later occupied by the U.S. The war itself had stimulated demand for the drug, but afterward the U.S. antidrug agenda and new U.N. antidrug bodies, 
commissions, and regulations directly challenged Andean coca. Thus, "Peru's relic legal industry was doomed" (ibid.: 181).

World War II and beyond tipped the balance against Peruvian cocaine. The country's legal factories became criminalized with the new world drug regime, and "Peru's last options for cultivating alternative markets were shattered on 7 December, 1941" (Gootenberg, 2008: 227). Further, "only the United States came out with postwar cocaine capacity and this capacity was geared to lower world use" (ibid.). The U.S. occupied both Germany and Japan - two major producers - and refused to absorb Peruvian cocaine, which had done well during the war. "No room was left for cocaine commodity chains autonomous of U.S. control" (ibid.: 22).

\section{-- Coca in the $19^{\text {th }}$ and $20^{\text {th }}$ Centuries: Drug Use \& Laws in the United States --}

"Dramatic shifts in attitude have characterized Americans' relationship to drugs" over many years (Musto, 1997: 21). From beneficial opiates and cocaine products in the $19^{\text {th }}$ century to fear of their dangers in the early $20^{\text {th }}$ century, and from tolerance of recreational drug use in the 1960s and 1970s, to intolerance beyond, recurring cycles of enthusiasm and abstinence are problematic for policy makers and the public, both of whom often do not remember the previous eras. This lack of knowledge of the past can make the formulation of a realistic policy difficult. In this section, I will briefly recount the history of drug use and drug control laws in the United States during the last 200 years. This history can provide a framework for understanding the state of drug control in the country today and resistance to it elsewhere. 
As previously demonstrated, "drugs are both physical substances with pharmacological effects and cultural icons with values and behaviors linked to them by the society in which they are found" (Gaines and Kraska, 1997: 5). James A. Inciardi (2008) suggests that the use of drugs and alcohol is both ancient and universal in human history. Generally, before modern times the drugs used by people in various societies were those derived from or found in local plants. With the $16^{\text {th }}$ century and exploration, trade began to move drugs throughout the world. Prior to the 1800s drugs were used in their natural forms, but the advent of organic chemistry made the isolation of morphine from poppies and cocaine from coca leaves possible by 1860 . The production of these substances coincided with the invention and newly widespread use of hypodermic syringes as well as a growing pharmaceutical industry.

Opium containing medicines were popular during the 1800s and their over-thecounter and prescription use was pervasive. Diacetylmorphine was synthesized in 1874 and sold over the counter as Bayer heroin beginning in 1898 (Inciardi, 2008; Musto, 1997). In 1884 purified cocaine became commercially available in the United States (Musto, 1997). Some officials even promoted increased trade in these new resources:

"By the 1890s, consuls and attachés on the ground assumed an active stance helping Peruvians upgrade coca cultivation and packing, as well as gathering commercial intelligence about the new local cocaine industry. These were the first visible articulations of Americans to coca in the Andes in attempts to promote its expansion and linkages to North America" (Gootenberg, 2008: 30).

Cocaine also eventually found its way into popular medicines. Some extracts from coca were used in wines and other beverages, the most recognizable being Coca Cola, first bottled in 1886 (Inciardi, 2008; Musto, 1997). Another one called Vin Coca Mariani received a medal of appreciation from Pope Leo XIII (Inciardi, 2008). Parke-Davis 
Company sold fifteen different forms of coca and cocaine products, including cigarettes and a kit containing hypodermic syringes (Musto, 1997). Some medical experts called cocaine a remarkable drug, harmless, and no more addictive than coffee or tea, while other medical professionals noted a number of ill-effects from cocaine, especially with long-term use.

Popular medicinal products containing opium and cocaine are collectively known as patent medicines. The production and sale of these tonics, syrups, and powders was unregulated. They were called patent drugs but none were actually patented since doing so would have required the disclosure of their ingredients. During this period in the U.S., health issues were generally regulated at the state level and most states had few controls (Boyum and Reuter, Inciardi, 2008; Musto, 1997). Medicine was thought to be best regulated by free enterprise and the federal government only intervened in matters of communicable disease or where government employees were concerned. Some changes in state laws were made near the end of the $19^{\text {th }}$ century in an effort to curb drug use, but the lack of a federal law or uniformity across state laws meant these efforts had little effect. At the same time, a growing public concern with mood altering substances, including alcohol, led to the formation of a variety of temperance movements. The Antisaloon League, for example, was founded in 1893. Musto (1997) claims that some drop in the use of patent medicines by the 1890 s was more likely the result of social stigma and fears of addiction than of any legal action.

The patent medicine industry eventually came to be criticized publicly by some doctors and others in medical journals and the press, but it was the publication of Upton Sinclair's The Jungle in 1906 that shocked the public and spurred Congress to action. 
That year, the Pure Food and Drug Act was passed (Inciardi, 2008; Musto, 1997). The new legislation meant that all ingredients and their proportions had to be indicated on the packaging of all food and drug products, but it did not outlaw the use of particular substances such as cocaine or opium per se. The popularity of patent medicines continued to decline soon thereafter.

The greatest effort to bring public control over opium and cocaine came in 1914 with the passage of The Harrison Act (Gaines and Kraska, 1997; Inciardi, 2008; Musto, 1997). Musto says the problem with creating a federal anti-drug law was how to avoid infringing upon states' rights and overextending the reach the federal government had into medical practices as part of free enterprise. The administration went the tax route instead. The Harrison Act "required a strict accounting of opium and coca and their derivatives from entry to the United States to dispensing to a patient" with taxes paid at each transfer and permits obtained from the Treasury Department by all but the patient (Musto, 1997: 26). The Act required all "who imported, manufactured, produced, compounded, sold, dispensed, or otherwise distributed cocaine and opiate drugs to register with the Treasury Department, pay special taxes, and keep records of all transactions" (Inciardi, 2008: 28). The Act allowed doctors to prescribe, dispense, or administer narcotics to patients for "legitimate medical purposes" and "in the course of professional practice" (ibid.). The interpretation of the act, though, made other use of these drugs a crime. Many doctors wanted to prescribe opiates or cocaine to addicts in order to alleviate the symptoms of withdrawal, but the Treasury Department did not agree that addiction was the same as other diseases or conditions that these drugs might legitimately be used to treat (Boyum and Reuter, 2005; Inciardi, 2008; Musto 1997). 
Subsequent Supreme Court cases upheld this interpretation. In 1919 Webb v. the United States found that it was not legal for a medical doctor to prescribe narcotics to an addict for the purpose of maintaining use and comfort. In 1922, the United States v. Behrman held that narcotic prescriptions for an addict are unlawful even as part of a cure program. The Jones-Miller Act of 1922 closed U.S. borders to all cocaine, though raw coca leaf was still imported for use in making drinks and manufacturing cocaine domestically at a limited and decreasing number of firms. In 1925, Linder v. the United States reversed the Berhman decision and said that addicts have a right to treatment and care like all other patients, but this ruling had almost no effect. By then doctors had become unwilling to treat addicts or take them on as patients (Gaines and Kraska, 1997; Inciardi, 2008). Instead, "a well-developed, illegal drug marketplace had emerged to cater to the needs of the narcotics-using population" (Inciardi, 2008: 28). One could argue that the law transformed addicts into criminals, and that these addicts had long been members of legitimate society, many of whom were led into addiction by their own doctors in the first place. Legal precedent and fear of prosecution among medical professionals helped construct addition as a crime rather than a health issue, a position represented by much of policy and enforcement guidelines at present.

The passage of the Harrison Act "ushered in a half-century of increasingly punitive anti-drug laws" and mandatory sentences for drug offenses up to and including life imprisonment and the death penalty (Boyum and Reuter, 2005: 5). It was the first example of the way that addiction has become equated with criminal behavior. The attitudes embodied in the Harrison Act were not confined to the domestic sphere. The international war on drugs began around the same time as domestic efforts for drug 
control. Musto (1997) says the impetus for a real international narcotics control strategy came in 1898 when the United States acquired responsibility for the Philippines. In 1905 Congress and President Roosevelt passed a mandate prohibiting any non-medical use of opium in the Philippines. By 1906, China had also begun its own anti-opium efforts. In part to appease Chinese anti-American sentiment, and in part to help control regional smuggling, the U.S. convened a meeting with regional powers to discuss the opium issue. The International Opium Commission met in 1909 in Shanghai. The thirteen nations present passed a resolution addressing the problem but did not sign an official treaty. Stronger restrictions would require an international conference. Twelve nations met in The Hague at the end of 1911 and signed a convention in January 1912 which required each country to enact domestic legislation controlling narcotics.

Opium use diminished in the U.S. during the 1920s and 1930s. After World War II, the United States and Britain proposed adding The Hague Convention to the Versailles Treaty so that ratifying the treaty also meant ratifying the convention and enacting a domestic drug control law, even if there was no drug problem to speak of for the parties involved. These early meetings were good for international cooperation on the drug issue but were also examples of "the belief, strongly held by the federal government today, that controlling crops and traffic in producing countries could most efficiently stop U.S. nonmedical consumption of drugs" (Musto, 1997: 26). Musto also notes they are early examples of the way that "the desperate need to solve the drug problem in the United States tends to create misperceptions of a foreign drug situation" (27). Both of these attitudes informing U.S. policy will be further demonstrated below. 
During the 1940s, World War II was more important in the public eye and drug problems became mostly invisible, though not entirely. The top firms, such as Maywood Chemical for Coca Cola, were influential in government decisions regarding coca imports, quotas, and regulations, as well as politics in the Andes. Merchandise \#5, an ingredient made from decocainized coca leaves and used in the flavoring of Coca Cola, was (and is) exempted from the Harrison Act, for example. The validity of the decocainization process was closely overseen by the Federal Bureau of Narcotics (FBN). Maywood, Coca Cola, and the FBN worked closely together between 1920 and 1960, and with the Peruvian government and clients, often sharing intelligence. Lawyers for Coca Cola frequently went to drug conferences and on missions along with government agents. Government regulation of coca limited Coca-Cola's competition within the U.S. and abroad, but also sent mixed messages. "For decades, the FBN did its best to protect and promote Coca-Cola's global market conquests, along the way muddying U.S. drug diplomacy" (Gootenberg, 2008: 204).

In spite of this bending to accommodate commercial interests, the U.S. position on drugs was absolutist whereas other countries had chemical interests (i.e., domestic companies involved in processing), or drug-producing colonies to act as lobbyists against nascent global drug regimes during the interwar period. The previously mentioned world conferences that were held on regulation and control had few real results. After WWII, with the break-up of colonial spheres and the downfall of Germany and Japan, the U.S. capitalized on both its position within the U.N. and a unifying antidrug consensus with the U.S.S.R. and China as allies (cold war tensions seemingly notwithstanding). The U.N. was willing to do whatever was necessary to avoid a post-war drug resurgence, 
especially of opium, and was fast to adopt the raw material eradication programs the U.S. had been pushing for since 1910 .

The League of Nations, and League members later, had been more concerned with opiates than with cocaine. Gootenberg (2008) suggests cocaine was included in the same category for regulation because of its status as a pet concern of the U.S., the resulting exaggeration of its dangers, and for the fears associated with the class and race of those who were the primary users of the drug. Peru and Bolivia generally ignored or defied early conventions, and Peru even withdrew from the League at one point. "In Latin America, ironically, only passionately anticoca Colombia (which had scant coca) and a few Caribbean colonial outposts joined on any regular basis in League antidrug deliberations" (Gootenberg, 2008: 216). But the League mattered, and it put drug control on the world agenda where it remains, associated cocaine with narcotics, and legitimized the U.S. anticocaine stance over time.

The global prohibition on cocaine came about more clearly only after WWII and the complete destruction of its other production and distribution chains (the Dutch, German, and Japanese), and the entry of Peru, and later Bolivia, into U.S. Cold War interests. During the interwar era, coca was still imported to the U.S., but only through one port of entry and to be used by Coca Cola. Elsewhere in the world, the "tolerant circumstances" of the interwar era "gave no incentive to illicit trade" (Gootenberg, 2008: 139). The year 1949 marked the world's first international cocaine bust. Peruvian Eduardo Balarezo was arrested in New York City as the head of a smuggling operation. Harry Anslinger of the FBN, and of Reefer Madness fame, assured the U.S. public that this bust, an example of the suppression of drug traffic to the country, had prevented an 
epidemic and more serious crime from happening in the future. But by the 1970s it would be clear his assurances were for naught.

By the 1960s, the popularity of drugs reemerged among the youth as a type of rebellion. All kinds of people were using drugs, not just the poor in the ghettos or the psychologically drug-prone, as had been the conventional wisdom. This was also a time of a new chemical age with increasing technology in drug production, both legal and illicit. There is little reliable data from the 1950s and 1960s about the links between drugs and crime; nonetheless, politicians have from that time on frequently claimed that 50 to $90 \%$ of crime in the U.S. is drug-related (Inciardi, 2008). Thus, President Johnson proclaimed a war on crime, and by extension a war on drugs. Nixon talked both about a war on drugs and a war on heroin specifically. The Nixon administration established the Special Action Office for Drug Abuse Prevention and two new agencies, the Office of Drug Abuse Law Enforcement and the Office of National Narcotics Intelligence. In declaring his war on drugs, Nixon sought to establish international controls and believed that if the source of drugs was overseas, then the solution should be, too (Boyum and Reuter, 2005). As a result of this stance, he put tremendous pressure on Turkey to ban the cultivation of opium poppies, for example.

Nixon began his war on heroin in the 1970s but the drug war really began to build momentum during the Reagan administration. Inciardi (2008) and Musto (1997) both cite public opinion surveys that indicate a trend toward conservatism among the general public from 1977 through 1987, showing more support for increased efforts at drug and crime control and less concern about the rights of criminals. During this same period, the RICO and CCE Statutes came into existence, and the Posse Comitatus Act was amended 
within the Department of Defense Authorization Act of 1982. These amendments allowed the Department of Justice to provide logistical support to civilian police (Inciardi, 2008; Kraska, 1997; Mabry, 1994). While there was still a prohibition on military personnel in law enforcement:

The entire war chest of U.S. military power did become available to law enforcement - for training, intelligence gathering, and detection. Moreover, members of the U.S. Army, Navy, Air Force, and Marines could operate military equipment for civilian agencies charged with the enforcement of drug laws (Inciardi, 2008: 258).

Thus, the drug war truly gained military technology and fire-power.

In 1988, the Reagan era began its zero-tolerance policy, extending the drug war to users, and included the idea that addicts can recover, though this attitude did not reflect sympathy. Addiction was still synonymous with crime. The idea was that addicts were not powerless, had started using drugs willfully, and therefore should be held accountable. Shortly thereafter, the position of drug czar was created by the Bush administration, and later the Clinton administration raised the status of the drug czar to the Cabinet level. Clinton's second czar, Barry McCaffrey, was an actual military general with experience in interdiction and many feared he would bring more militarization into U.S. drug policy in action. Today, U.S. consumers spend about $\$ 38$ billion annually on cocaine, roughly two thirds of all illegal drug expenditures, and money is the main reason cocaine is the primary target in the war on drugs (Gootenberg, 2008).

The rise of anti-cocaine sentiment coincided with the growth of illicit use in the early twentieth century, and illicit trafficking rose as global prohibition was consolidated in the mid-twentieth century, which in turn raises questions about which came first. The 
"elevation of cocaine into a world menace... was a predominantly American quest" as

differing ideas about it existed in Europe and Asia during the first half of the $20^{\text {th }}$ century (Gootenberg, 2008: 190). Up through 1945, the U.S. "proved adept at containing cocaine within its own borders and among its own citizens, with few objections, but the U.S. policing regime failed when diplomats tried to foist its ideals on the rest of the world" (ibid.). Instead, "a 'multipolar' cocaine world prevailed" (ibid.). Even so, from 1945 through 1965, the U.S. instituted "global anticocaine hegemony" and yet that is precisely when illicit cocaine grew and spread and “quickly spiraled into today's global economy of cocaine" (ibid.).

\section{-- The Rise of the Illicit Cocaine --}

The growth of commodity chain circuits in the early $20^{\text {th }}$ century, which broke apart during WWII, were "a prelude to the illicit cocaine circuits that were to reintegrate the eastern Andes to the outside world by the 1970s" (Gootenberg, 2008: 107). The decades 1910 to 1950 were an "era of mounting political and market constraints on coca and cocaine, related in part to rising international narcotics control" (ibid.). In 1915, the U.S. was a "lone crusader in world anticocainism" and Germany was often portrayed as an "evil drug empire" for its continued imports and use of coca and cocaine (ibid.: 122).

The late 1940s brought swift and sweeping changes to Peruvian cocaine policies, which established a state monopoly, revoked all existing licenses for legal cocaine manufacture, and "radically revised" the penal code on production and traffic to agree with international norms (Gootenberg, 2008: 232). Illicit cocaine was an almost immediate response to the loss of legitimate markets postwar, popping up first on a small 
scale to Havana and New York. Prohibitions within Peru displaced the drug to other parts of South America, thus requiring broader hemispheric controls, but U.S. officials still thought wiping out cocaine entirely was fully possible.

Between 1920 and 1950, little organized illicit cocaine activity existed. The few users in the U.S. were mostly supplied by local pharmacies under the counter or through small-scale, individual smugglers, neither of which were on the U.S. radar until after the war. An increasing number of smuggling incidents involving sailors from Peru and Chile who were caught bringing cocaine into U.S. ports were recorded in the late 1940s. These were mostly individual, isolated cases involving relatively small amounts of the drug, often no more than 250 grams. Cocaine use, though small, had survived among various sectors of the population in the U.S. and Europe. It was particularly associated with artists, musicians, and prostitutes. Little information is available about the origin of the cocaine in these few recorded incidents, but U.S. authorities often blamed corrupt officials in Peru and other parts of South America for failing to prevent its export, an early example of the policy of stopping drugs at their supposed source.

From 1949 through 1950 Peruvian authorities carried out a large scale crackdown on cocaine and closed all remaining legal cocaine factories, uncovering several clandestine ones in the process. The Peruvian suppression of cocaine effectively moved smuggling operations outside its borders to Bolivia, Chile, and Cuba during the 1950s, though the crude cocaine or pasta básica that was refined into cocaine remained primarily a Peruvian product. As one of the postwar "global sin capitals" Havana, and Cuba in general, was best known for its growing role in the cocaine trade of the midtwentieth century. Cocaine fit neatly with its gambling and prostitution for pleasure- 
seeking American tourists. By the mid-1950s "Interpol regarded Cuba as the main staging point for Bolivian ${ }^{2}$ cocaine entering the United States" (Gootenberg, 2008: 265). The 1959 Castro revolution changed this climate. Traffickers fled the island and dispersed to other parts of the Caribbean and Latin America. This migration essentially created a "new professional international cocaine trafficking class...composed of Cuban exiles" (Gootenberg, 2008: 266). By 1962, Miami had become the second port of choice for cocaine entering the U.S. partly because of the large population of Cuban exiles there.

Cocaine was also smuggled cross-border into and through Brazil where it was popular in the cities, and Argentina had links to Miami and Europe as part of this new illicit cocaine trade. Both countries' roles were reduced after military regimes came to power in the mid-1960s. Similarly, the 1973 coup in Chile also ended its role in cocaine traffic, pushing it into Colombian circuits. Prior to the 1970s Colombia was left "entirely off official mapping of cocaine routes and trouble spots" (Gootenberg, 2008: 273). Mexico, with its U.S. border and history of smuggling traditions, was a "portentous" route for developing cocaine traffic, and those in the country had connections to Bolivian producers and Cuban exiles already there.

Three main things fueled the continuation of the illicit drug boom of the 1960s and 1970s: 1) the collapse of postwar development schemes in Peru's Huallaga valley, 2) the linkage of Andean cocaine capitalism, via cold war events in Chile, to a newly and

2 During the first half of the $20^{\text {th }}$ century, Bolivia had not industrialized its cocaine in the way Peru had. After the crackdowns of 1949-1950 in Peru, "Bolivia rapidly transformed over the next decade and a half into the major incubating site for illicit cocaine" (Gootenberg, 2008: 276). The political climate and social programs that changed the character of land ownership in many rural areas of the country are part of what made this transformation possible. Unlike the opium and heroin organizations of previous decades, the cocaine trade was not run by a mafia or a hierarchical transnational criminal class, but instead by "a loose, diverse, and independent diaspora of Latin American ethnic traders, elite gadflies, political refugees, and petty criminals blazing the new corridors to the north" (ibid.: 287). It was cooperative, entrepreneurial, and initially non-violent, especially prior to cartelization in the 1970s. 
quickly developing class of Colombian traffickers and entrepreneurs, and 3) the Nixonera revolution of culture and politics that underlay new drug demand in North America. These three shifts transformed "the legacy of Peru's historical crude cocaine and the modest smuggling of early narcos into the massive and socially destructive South American drug bonanza of the 1970s and beyond" (Gootenberg, 2008: 291).

During the Truman era, Peruvian and U.S. officials became interested in connecting the eastern region, the Huallaga valley in particular, to the rest of Peru and rediscovering or incorporating forgotten lands and their riches into the interests of the state. A research center and a new university were set up in the town of Tingo María, about $135 \mathrm{~km}$ from Huánuco. This imagined conquest of Peru for Peruvians, and the recovery of supposedly underutilized lands, became a goal of the president during the 1960s, and brought a large number of new settlers and migrants into the region, both officially and unofficially. In 1968 the military regime instituted an agrarian reform program and promised greater integration of the peasantry into the state. But by 1973 , an overextended and failing regime left many poor people in the Huallaga valley without services or attachments. For example, the state lumber enterprise collapsed and most of the workers who had been left to fend for themselves turned to growing coca to make a living. The province had gone from "labor-starved to overflowing with impoverished workers" in a matter of years (Gootenberg, 2008: 296). It was "amid the regional power vacuum, [that] a stampede to coca ensued" (ibid.).

The 1970s brought increasing panic and emergency to the tone of U.S. reports about the return of coca growing and pasta making. The method used was similar to that for crude cocaine that had been brought to the region by Bignon back in the 1890s. This 
technique was "easily transferred to and eagerly adopted by even the illiterate working peasants" - the great secret of the Huallaga trade (Gootenberg, 2008: 299). The area of Tingo María became cocaine's Wild West. The state recognized the problem but lacked capacity to contain it because of its own continuing crisis of governance. Similar conditions had prevailed in Bolivia a decade earlier. "Socially entrenched in this popular illicit sphere...Peruvian cocaine capitalism was essentially unstoppable" (ibid.).

The 1973 coup in Chile cut off cocaine's central corridor to the north. A DEA official convinced Pinochet to jail or exile known traffickers arguing that drug money could be used by the left to plot against the regime, an early example of drug's links to terrorism and state security. Colombian smugglers, primarily of marijuana, cigarettes, and contraband appliances, seemed primed to put their existing routes along the coast to use for cocaine. But the city of Medellín, isolated in north central Colombia and away from the coast, was also "ready for a newly ambitious economic activity" as its textile sectors declined (Gootenberg, 2008: 302). Again, the economic health of a country or region is always a principle factor in the growth and sustainability of the drug trade.

Colombians began to import pasta básica from Peru and Bolivia for refining into cocaine hydrochloride and export to the U.S. and Europe. Multiple routes and more family and clan organizations began to develop, increasing competition as the size of operations grew. By 1980, Colombians were exporting more than 100 tons of cocaine to the U.S. Demand was not necessarily created by this increased supply; Gootenberg (2008) instead suggests that demand can be politically constructed and the Nixon years were a "decisive turning point" for cocaine use in the U.S. (307). Heroin had been the official foe in Nixon's declared war on drugs, but by the 1970s, cocaine use surpassed 
heroin in the United States. During the 1960s, cocaine culture crossed over from its location within racial categories. Music from the 1920s, some of it racially characterized and celebrating cocaine, was being revived by white rock musicians thereby mainstreaming something that had been an underground phenomenon. The first survey data of the early 1970s on drug use showed that young people were experimenting, and about $10 \%$ of college students had tried cocaine.

In 1973 the DEA was launched; Gootenberg calls it an "outsized new drug agency" and "an internationalized bureaucracy with domestic powers that have been associated with Nixon's project of fostering a larger repressive state" (307). The U.S. cracked down on marijuana, a drug closely associated with the antiwar movement of the 1960s, which may have opened an opportunity for increased cocaine imports in order to fill the void. A similar explanation for rising use of cocaine comes from the dismantling of the French Connection and the Turkish poppy ban that limited heroin supplies around the same time.

The renewed popularity of cocaine was troubling to those who thought it had vanished in the 1920s and that it rarely crossed borders. Even so, the White House deemed it a low priority in 1975 . The drug was still considered an elite, soft drug. Reports noted little demand for treatment of cocaine addicts and many divergent opinions about its dangers. Unlike the rebellious counter-culture drug use of the 1960s, cocaine use in the 1970s can be characterized more as a part of mainstream capitalism and a call to consumer rights. It fit the model of conspicuous consumption and was associated particularly with the visible indulgences of the disco culture. 
During the 1980s, the Medellín-Miami corridor had become heavily policed and traffic shifted to a North Mexican route. By the 2000 election in Mexico, where the PRI lost its stronghold on national politics for the first time in decades, the route had shifted back to the Caribbean, especially through Hispaniola. Gootenberg notes the porous nature of Haiti as key to this traffic, though the Dominican Republic is just as permeable. While the U.S. claims some success in Colombia, such as increasing prices for wholesale cocaine and decreased production, evidence now points to the replanting of areas in Peru and Bolivia "where eradication policies left a deep scar in peasant unrest and antiAmerican politics" (Gootenberg, 2008: 315). Cocaine traffic now moves through Africa into Europe, supplying new users in the former Soviet states, and through the vast unpoliced slums in Brazilian cities. The drug appears to be replicating itself as the global commodity it was 100 years ago.

"The modern and progressive image of early-twentieth-century cocaine is now long extinct due to the drug's associations with hyperviolent drug lords, atavistically clad in a veritably medieval (i.e., premarket) discourse about crusades of good against evil" (Gootenberg, 2008: 320). Policy has combined a "militant ideology of cutting off drugs at their source" with an "export of prohibitions" and Gootenberg suggests that had the U.S. appropriated or co-opted Peru's production into a U.S. commodity chain, it may have mitigated surplus drain into the illicit (ibid.: 321 ). Instead, the drug war can easily be dated all the way back to 1906-1914 which means it has lasted for a century, with little to show for it. Drug control is a contradiction in terms. The balloon effect is not just geographical. Drug policy contributes to the increasing wealth and tactical sophistication of the traffickers over time, and to the "moral and political decay of Andean states" 
(ibid.: 324). I would add it contributes to similar decay in many states elsewhere in the region and the world since the balloon effect has spread drug operations so widely.

\section{-- Conclusions --}

Scholarship on narcotics control is prevalent and prolific especially as "the campaign to ban menacing drugs was one of the first models of internationalized norms and policing institutions" (Gootenburg, 2008: 189). But this scholarship fails to separate cocaine from other "genuine narcotics" with which it is frequently "conflated and confused" (ibid.). Few studies are "genuinely transnational or constructionist, connecting the political and legal aims and ideas of would be drug controllers in metropolitan sites like Washington and Geneva with the realities and reactions at the other end of the drug commodity spectrum" (ibid.). The one-sidedness of international drug policies fostered resistance to global prohibition early on. Consideration of the objections from the producing side helps "illustrate possible historical alternatives to prohibition or to the illicit drug trade that followed it" (ibid.). This argument may seem counterfactual and the connection to the modern-day situation is not entirely clear. Instead we must ask if there is a possible starting point for new alternatives or if the drug trade is too entrenched.

It is ironic given its history of exports that "cocaine is among Latin America's most successful and indigenous export industries. It remains an 'American' industry and is still running strong despite heavy pressures against it" (Gootenberg, 2008: 287-288). It demonstrates "bottom-up local agency" combined with "a stubbornly entrenched regional peasant economy" (ibid.: 288). The grassroots nature of the trade combined with both the economic vulnerability and the tenacity of the people involved in keeping 
production going should make it harder to characterize as purely evil, and is also a part of the industry's staying power. A lucrative and once legitimate enterprise has suffered from a "politics-driven shift underground" (ibid.: 291).

In the 1930s "the political establishment believed that drug dependence could be legislated out of existence simply by passing enough comprehensive laws" (Inciardi, 2008: 35). At the same time, doctors saw drug dependence as a disease to be treated while police saw it as a crime in need of harsh punishments for the sake of society as a whole. These three trends still seem to be with us today in the war on drugs and in the debates over the supposed merits of legalization, decriminalization, and harm reduction programs.

In the U.S. "patterns of drug abuse are continually shifting and changing. Fads and fashions in the drugs of abuse seem to come and go" (Inciardi, 2008: 65). Which drugs are the most popular and profitable change, yet none - nor the demand for some kind of drug - disappears forever. Alcohol has been the number one intoxicant for thousands of years. Opium and other narcotics have been popular in the United States for nearly 200 years, and other drugs, especially synthetics like methamphetamine and ecstasy, "just seem to keep coming and going and reinventing themselves" (ibid.). The laws and policy shift and change much less often. The overarching prohibition on controlled substances remains, and most people would probably agree that is how it should be. What is less certain is how well the strategies and tactics used to enforce the law actually work.

U.S. prison populations grew threefold between 1980 and 1994, the result of severe drug laws, especially those pertaining to crack. "By 1995, more young black men 
were in prison than in college" (Gootenberg, 2008: 313). Meanwhile, coca production doubled from 1982 to 1986 alone, and prices dropped in response to interdiction efforts. Political developments in Peru further isolated and marginalized coca producing peasants, in some cases aligning them with the terrorist or anti-state group Sendero Luminoso, while those in Bolivia unionized and campaigned for integration into national politics. Both of these divergent paths seem to support continued production for export and profit. Ritual, legal use of coca leaf now constitutes only about $10 \%$ of the total crop. Coca growing in Colombia, cultivation that has increased in response both to growing demand and to repressive measures in Peru and Bolivia, is "divorced from indigenous coca traditions" (ibid.: 315). Colombian crops are grown purely for the enterprise, and are stronger and more efficient. The narrow focus of policy in the $20^{\text {th }}$ and $21^{\text {st }}$ centuries brings full circle the trend begun with the conquest of the New World. Medical uses of its extracts and their commercial success and potential notwithstanding, the coca leaf is still considered the source of degraded, backward, uncivilized, and even evil practices.

\section{U.S. Drug Policy - The Baseline}

\section{-- The Anatomy of 10 Years of Policy --}

In this section, I examine the U.S. State Department's International Narcotics Control Strategy Report (INCSR), published annually, from 1996 through $2007 .^{3}$ I will show that the language of the reports consistently demonstrates an adherence to the same narrow principles year after year, with few adjustments. Targets are always external drug supplies - especially for cocaine and heroin - and demand reduction comes last on the

\footnotetext{
${ }^{3}$ On a technical note, in 2001 the method for numbering the INCSRs shifted so that the report published in March of 2002 covering the year 2001 is labeled 2002 and there is no 2001 report.
} 
list of goals in the drug war. Similar language and the rhetoric of the drug war carry through the reports during the time period studied here and provide justification for continuing with the same strategy. Only a major security crisis for the U.S. has had any impact on the focus or the method, and this has only served to bend the drug war to fit into the new strategic mold of the war on terror. The INCSR includes six main areas of focus, which cover the external production and transport of drugs, the drug trade's links to terrorism, the training of personnel and institution building abroad, extradition and prosecution of foreign drug criminals, the adaptive ability of the drug trade, and some discussion of alternative development programs and strategies. Throughout, democracy is the ideal by which and for which the drug war is fought.

Beginning with the 1996 report, emphasis is placed on stopping the entry of cocaine and heroin into the United States. Training, strengthening political will, and judicial reform abroad all work toward the goal of "promoting the creation of host government systems which are compatible with and serve the same broad goals as ours" (INCSR, 1996). The arrests, extradition, or deaths of key cartel figures are frequently cited as evidence that "syndicates are highly vulnerable to coordinated international pressure sustained over time," while the report also notes the level of change and adaptation by drug markets in response to these same efforts (INCSR, 1997). After September 11, 2001, the war on terror became an integral part of the INCSR, often overshadowing other kinds of programs and efforts to reduce the appeal of the drug trade in poor countries.

The tone of the reports repeatedly asserts that the drug trade is adaptable but not invincible. At the same time, the drug war is not seen as something that occupies most 
people's attention on a regular basis, but is something important that slowly and steadily

works toward fulfilling its objectives:

Viewed out of context, the many achievements of individual countries may seem insignificant. Small steps do not grab headlines; many never come to the attention of the media. The countless routine drug seizures, the jungle drug labs or airstrips destroyed every day, the arrests of corrupt officials, or the improved performance of police and judicial authorities benefiting from USG assistance receive at best only fragmentary coverage in the world media. But these small steps add up to important and lasting gains at the expense of the drug trade. As we have seen, cumulative achievement pays off. Over the long term, such steady progress offers the best hope for transforming a potential threat to the stability of nations into a manageable nuisance (INCSR, 1996).

The drug war is not a losing battle, but neither is it one that seems to have a clear end in sight. The idea of a manageable nuisance implies that this war could be never-ending, that it is not possible to eliminate the drug trade entirely, and that it is different from other wars that end with a winner and a loser.

\section{-- Outward-Looking Strategy and Links to Terror --}

In the mid-1990s "all cocaine and heroin... [were] produced outside the United States," and cocaine remained the number one priority (INCSR, 1997; emphasis added). More than 8000 people were trained by the U.S. to facilitate "foreign law enforcement self-sufficiency through infrastructure development" to achieve the "establishment of effective host country enforcement institutions, thereby taking drugs out of circulation before they begin their journey toward the US" (ibid., emphasis added). International organizations and multi-lateral efforts attempted to "decrease the perception that drugs are exclusively a U.S. problem" (INCSR, 1998). Both the OAS and CICAD, for example, have worked with the USG in confronting drugs. "The need for demand 
reduction is obvious" but it is usually talked about in a general sense in these reports. Demand is everywhere, not just in the U.S., but demand reduction cannot be undertaken anywhere except in conjunction with supply control. Instead, it is addressed in terms of support for efforts in producing countries. Only the 2002 report recognizes that demand reduction is "a fundamental and critical part of controlling the illicit drug trade" (INCSR, 2002).

In 1998, the drug war saw a year of "solid gains at the drug trade's expense" (INCSR, 1998). The numbers reflected the lowest level of coca crops in ten years, though Colombian cultivation had risen. The emphasis in the 1999 report remained on supply control, but there was some recognition of other areas where a change in policy might be affective:

In the real world of counternarcotics programs...crop control has enormous political and economic implications for the producing country, for it inevitably means attacking the livelihood of an important sector of the population (INCSR, 1999).

In Peru and Bolivia, the right combination of law enforcement and alternative development programs in place of eradication were thought to have shown promise. At the same time, a coca field is a large stationary target and eradication is much more cost effective than interdiction, where a large number of man-hours are required to search boats and trucks.

Even so, interdiction continued to be central to U.S. policy. In 2002 there were several new Port Security Initiatives. The first, Container Security Initiative (CSI), is a security regime created to identify and inspect containers. Sixteen of the world's twenty high-volume 'megaports' agreed to participate. "We intend to expand CSI to all ports 
that ship substantial amounts of cargo to the U.S., and that have the infrastructure and technology in place to participate" (INCSR, 2003). In response, we should expect illegal trade to shift to smaller, less-developed locations, as noted by Nordstrom (2007). One might expect several Dominican ports to be included in this initiative since an estimated $8 \%$ of cocaine arriving in the U.S. comes through Hispaniola, with half of that coming through the Dominican Republic (INCSR, 2003). That is not the case as only one port in the Dominican Republic, one just east of the capital (Caucedo, Distrito Nacional) is listed as participating as of December 2007 (for a complete listing see http://www.cbp.gov/xp/cgov/trade/cargo_security/csi/, 2007). Four years prior, no ports for the country had been listed at all.

Plan Colombia was approved in 2000 for $\$ 1.3$ billion to support the Colombian government in the fight against drugs, and for broad social reforms. By 2001, cocaine was still considered the number one threat to the United States. As in previous years' reports, the decreasing numbers for coca cultivation in Peru and Bolivia do not seem to count for much when compared to the amount in Colombia, especially cultivation in FARC controlled areas. The 2002 report is the first one to link drugs with terror directly, and a new term is introduced: narco-terrorism. "What began as a marriage of convenience has now become a partnership dominated by the insurgents" (INCSR, 2002). This conceptualization strengthens the argument that drugs are antithetical to democracy. In the post-September $11^{\text {th }}$ mentality, nearly everything is linked to terror. The impact of the events of September 11, 2001 created an "added urgency and intensity to a robust process already underway" in the war on drugs (INCSR, 2002). Drug "revenues fuel terrorism and the decades-old civil war in Colombia" and yet it is only starting with 
in the 2002 and 2003 reports that this link is made explicit and discussed as such (INCSR, 2003). The report further says that "all the insurgent and paramilitary groups depend on [drug money]" (ibid., emphasis added). The drugs-terror link is a given and is treated as a long-standing fact. It can also be seen as justification for escalation of the drug war, providing more fuel for the fire.

The drugs-terror link means that "as the single greatest source of illegal revenue, the drug trade has long been the mainstay of violent political insurgencies, rogue regimes, international criminal organizations, and terrorists of every stripe" (INCSR, 2003). Supply control remained an important strategy along with "efforts aimed at reducing worldwide drug consumption" which "took on increased importance and served the national interest due to its potential for reducing the income that criminal and terrorist organizations derive from narcotics trafficking" (INCSR, 2004). All aspects of the illicit drug trade, from producer to consumer, therefore contribute to worldwide terrorist organizations. "The illicit drug trade is a threat to national security and international stability. It is inextricably linked with transnational organized crime and many terrorist groups" (INCSR, 2005, emphasis added). The war can be against people at all levels; dealers and users alike are enemy combatants.

The language of the report indicates that many individual battles have been won, but whether we are winning or are even able to win the war on drugs is uncertain. Demand is treated equally in all nations as "rising global demand for illicit drugs [is] the principle narcotics-related threat to the U.S.” (INCSR, 2004). Once again, this implies that the source of the problem for the U.S. is an external one: Global demand for drugs. 
The report noted "remarkable progress" during 2003 “despite a 'perfect storm' of conditions potentially favoring international criminal activity" worldwide (INCSR, 2004). These conditions included various wars and insurgencies, political problems around the globe, and economic problems, indicating some recognition of the various structural and other factors that may abet criminal activities. "Our goal is to...reduce the drug trade from serious threat to our people and global security - to a common nuisance, controlled through an international network of legal cooperation" (INCSR, 2007). In ten years of reports, what had been a major threat to the stability of nations and was hoped to become a manageable nuisance, has become a threat to global security and the goal is still to make it a common nuisance. The war on drugs is treated as something that is ongoing by 2007 , and perhaps not $100 \%$ winnable. In spite of the recognition that drugs may have to come to be seen as a common nuisance and a regular law enforcement issue, it is still characterized in grand terms. This similar language and approach, in spite of the years of effort, indicates that little has changed or been accomplished.

\section{-- Training, Institution Building, and Extradition --}

The illegality of drugs drives their profitability and "stemming their flow requires a coordinated international effort" (INCSR, 2005). The U.S. needs others to enforce its own policies and those of the United Nations. Cooperative measures between governments are required to face the challenge of wealthy international drug syndicates and to reduce the attraction of new recruits to the drug trade. "Increasing numbers of bilateral agreements between the U.S. and Caribbean nations is moving us toward our goal of a 'seamless' territorial airspace" (INCSR, 2003). At the time of publication of the 
2004 report, twenty-three bilateral agreements were in force between the United States and Caribbean or South American governments, working toward continuing this goal of creating seamless airspace throughout the entire western hemisphere. By June of 2005, the U.S. had 30 bilateral agreements in force in South and Central America and the Caribbean, again "moving toward our goal of eliminating safe havens for smugglers" (INCSR, 2006). These efforts appear to be bringing all drug control in the hemisphere under the purview of U.S. policy and operations.

The drug trade may be "far from omnipotent" and "vulnerable on many fronts" but "above all, it needs the protection of a reliable core of corrupt officials in all the countries along its distribution chain" (INCSR, 1997). By this account, the drug war is not supported and continued by the laws of supply and demand alone. It requires - and receives - complicity at the highest levels of government. This may be true to an extent, although even if no officials were corrupt, there likely would still not be enough of them to stop the flow of drugs around the world. Eliminating corruption at every stage does not necessarily create the manpower needed to search everywhere and every way that drugs are produced and moved, nor is eliminating corruption an easy task or one that can be accomplished in the short term.

Political will is necessary to fight the drug war, a point emphasized routinely in these reports. The 2002 report specifically mentions low government salaries that facilitate bribes and kickbacks. Political will is thus closely related to the economic health of a state. The drug trade needs people and it can pay them well, often much better than the legitimate economy can, and the report acknowledges that the profit margin on 
drugs is enormous. Likewise, demand for drugs has remained steady, so profits and benefits from drug money are also somewhat steady.

On the issue of strengthening institutions, the 2003 report again points out the problem of low salaries for judges and other judicial or police employees, as well as the importance of the fact that most of these individuals receive little or no protection from criminal retaliation. Many of these public servants have been targets of violence in Colombia, as well as in the Dominican Republic, where there is widespread insecurity from a combination of low salaries, low institutionalization of law enforcement, and the influence of large drug syndicates. This combination of factors creates an environment where illegal practices can thrive at all levels. The reports frequently speak of political will and cooperation from foreign governments as the key to combating drugs. "The drug trade draws strength from the conditions of economic, social, and moral decay that corruption fosters" (INCSR, 1998). The question of whether the drugs or the corruption came first is never explicitly addressed, nor are many of the economic and structural problems that are foundational to the link between drugs and corruption, except briefly in the specific country sections of the report.

Beyond the logistical problems of stopping drug traffic, the outward looking nature of the U.S. strategy to limit or stop the flow of illegal drugs to the U.S. "depends on how effectively we attack drug supply beyond the country's borders" (INCSR, 1997). I see two problems with this. The first is that it places blame on other governments. Certainly corruption and weak government are a problem and allow for more illicit activity to occur. At the same time, many governments, corrupt or not, simply do not have the capacity and resources to deal with the drug trade as it has grown over the years. 
The U.S. position seems to say that if there were no supply from abroad, we would have no demand for drugs. But as the preceding sections of this chapter clearly show, demand is not a new phenomenon and it was not always illegal. That legal cultivation has been continuous further confuses the absolutism of U.S. policy. The second problem is that the U.S. may be expanding its jurisdiction beyond its borders. There may be a fine line between cooperating with other governments who are a party to the same U.N. agreements on drugs and exercising a policy of extra-territoriality. The extra-territorial policies of the U.S. often lead to the extradition of drug criminals to the U.S. to face charges there.

In answer to the criticism that the extradition of those suspected of drug crimes to the U.S. is a "derogation of national sovereignty," the 2003 report claims that a "willingness to extradite" by other national governments is "a key indicator of political will and mutual trust" in the war on drugs (INCSR, 2003). The mutual nature of this relationship is not obvious since the USG does not trust other governments to prosecute within their own judicial systems, therefore raising extradition to such a high level of importance within U.S. policy. "Governments fighting the drug trade realize that extradition is a boon to their own law enforcement effectiveness," but what is not clear is how extraditing and sending criminals to face charges elsewhere can strengthen one's own domestic institutions (INCSR, 2005). In addition, the extradition system is not perfect, especially in cases where there is a clash of values between domestic systems. For example, a 2001 decision by the Mexican Supreme Court prohibits extradition for cases that carry potential life sentences, which are illegal by Mexican standards, and the Mexican government cannot extradite citizens somewhere they will receive harsher 
punishments than if they were tried at home. Life sentences and the death penalty have become points of contention between the USG and Mexico on this issue.

The USG prides itself on its ability to arrest and convict foreign nationals in the war on drugs and holds each success up as an example to the rest of the world about what should be done and what will happen to others who follow the same path into international organized crime:

The host of notorious foreign drug criminals serving long prison terms in the U.S is a sober reminder to the most powerful international criminals of what can happen when they can no longer use bribes and intimidation to manipulate the local judicial process. Governments are increasingly willing to risk domestic political repercussions to extradite drug king-pins to the United States, and international public acceptance of this measure has steadily increased (INCSR, 2007).

There are several things about this statement that are troubling and worth addressing. First, should international drug crimes be prosecuted in the domestic courts of the United States? Even if the domestic procedures of a particular state are inadequate for pursuing criminals, an international crime needs an international venue for prosecution rather than another domestic court. When do the courts of the U.S. gain jurisdiction over crimes committed in other countries or in international air and waters? Second, why should U.S. taxpayers have to pay to keep foreign criminals in prison in the United States? To some extent, it might be fair for the U.S., as the largest consumer of drugs, to take on the cost and effort of trying the bulk of drug crimes or to share responsibility with other drugconsuming states in Europe, though Brazil is now the second biggest consumer of cocaine (Bagley, 2009). Nevertheless, one is not likely to convince the tax-paying public to take on this responsibility, nor is the distinction between producing and consuming countries so clear cut. Third, are programs designed to improve the institutions of police 
and courts elsewhere meant to make it so that eventually these criminals will not have to be extradited at all but can be processed, tried, and jailed in their own countries where many of their alleged crimes take place? This question is never addressed in the INCSR; rather, improved systems point to better processes for extradition in the future and not to reliable, autonomous court systems able to handle these cases on their own. As we shall see in the following chapters, efforts to reform domestic procedures may not be achieving any of these goals in the short term either.

Training by the U.S. also works toward "promoting the creation of host government systems which are compatible with and serve the same broad goals as ours" (INCSR, 1997). This suggests some imposition of values and goals within national systems from the outside. One might object to the intervention and interference in the internal affairs of another state as a violation of sovereignty even if there are positive and cascading effects later. Or one might ask whether or not it is better have the same kinds of law enforcement institutions everywhere than to have as many different practices as there are states. The idea is to create better coordinated efforts through similar practices, but at the same time, there needs to be room for incorporating best local practices into the development of new institutions by outside sources.

\section{-- Linking the War on Drugs to Democracy and Political Will --}

The INCSR frequently touts its own noble mission of combating drugs and the problems associated with them in society in order to preserve democracy:

Our joint efforts are keeping the drug trade at bay - no easy feat in the post Cold War era when drug trafficking, terrorism, and international organized 
crime promise to become three of the dominant forces threatening democratic order and international stability in the next few years (INCSR 1996).

Even so, the methods used and efforts made to stop drug traffic often come into conflict with the goals of a free and democratic society:

The most powerful weapon in fighting the drug trade is an intangible: political will. The best-trained counternarcotics force, equipped with state-of-the-art police and military hardware, cannot succeed without the full commitment of the country's political leadership. When political leaders have had the courage to sacrifice short-term economic and political considerations in favor of the longterm national interest, we have seen the drug trade weaken" (INCSR, 2003, emphasis added).

These words signal a danger zone: that area where civil rights become subordinate to security and democratic practices are suspended or endangered in the name of fighting crime. In all of the INCSRs reviewed here, there is an ongoing concern about the threat of drugs to democracy, and how the war on drugs is fought through cooperative efforts among democratic nations. "In democracies, the drug trade flourishes only when it can divide the population and corrupt institutions. It cannot withstand a concerted, sustained attack by a coalition of democratic nations individually committed to its annihilation" (INCSR, 2002). Drugs then are antithetical to democracy, an idea that was particularly striking to me as a reader, and begs the question of whether there are no allies in the war on drugs with other forms of government. We might also ask just how democratic all the so-called democracies in the international anti-drug coalition are, and how democratic their methods for fighting the drug trade and drug crimes are as well. The drugsdemocracy link may not be as implicit as these reports indicate. Throughout the reports because drugs are assumed to be incompatible with democracy, any kind of alternative policy option that would include toleration or legalization is not possible within a 
democratic society by definition. This stance is limiting to policy and creates rigidity where some flexibility may be warranted.

The "drug trade's wealth makes it as great a threat to democratic government [as] an armed insurgency" (INCSR, 2002). While this may indeed be true, something is missing in the point, which demonstrates the U.S. government's tendency to emphasize democracy - though not explicitly defined - as all-important. It might be better to frame the drug trade as a threat to society as a whole, whether fully democratic or not, since corruption and violence undermine other aspects of the political culture and civil society. Administrations that are fixated on democracy alone may tend to overlook other elements that are conducive to its development, particularly civilian control of government and military forces.

What is also not clear is how democracy itself is a good weapon for fighting the drug trade. In theory perhaps it is the will of the people to keep the resistance to drugs going, or to legalize, regulate, and keep the profits generated by drugs. The report instead refers to "the vicissitudes of domestic politics" as part of the obstacles and setbacks experienced by the drug war (INCSR, 2003). Peru and Bolivia "face growing domestic political challenges from cocalero groups that link coca cultivation with national identity and sovereignty" (INCSR, 2004). The report claims that these groups are abetted by traffickers to "promote coca cultivation and consumption as an ancient, indigenous rite that must be protected" and implies that this is not the case (ibid.). As I have shown, the use of coca is indeed an ancient practice, and historically its use and meaning have frequently been misappropriated and changed, so while it may be plausible that the drug syndicates have artificially created a link between indigenous identity and 
coca for their own gain, that is not the whole truth. The assertion forgets the agency of the indigenous population and their role in reviving coca growing during the 1960 s and 1970s. It is also important to remember that coca and cocaine are not the same and should not be conflated as this argument seems to do.

"Radical movements have seized upon the historical tradition of coca cultivation as a rallying cry for indigenous rights against the dominant urban culture" and "by equating coca eradication with an attack upon both the poor in general and the indigenous poor in particular, a burgeoning anti-establishment political front has coalesced around the cocaleros (coca growers) movement" (INCSR, 2003). Instead of viewing it as the will of the people, this language again implies that the connection between coca growers and indigenous rights is tenuous and disingenuous. The report also mentions that the government cannot ignore the cocaleros entirely either, considering the number of votes for Evo Morales in the 2002 presidential election in Bolivia. One wonders if the same report writers would recommend ignoring this group if it were a smaller minority unable to exercise electoral power.

Increased indigenous activity in politics is just one example of increasing resistance to eradication, especially as a policy pushed by foreigners and others outside the state. The question of indigenous rights as members of a democratic society complicates and further raises the costs of eradication. Resistance to existing interdiction and eradication policies by citizens seems both reasonable and democratic, but appears to be something of a nuisance to the USG which is accustomed to being a dominant power in counter-drug policy or to working with a majority of foreign governments that supposedly share its stance. An alternative cultural view of coca is thus difficult to 
incorporate into the existing orthodoxy of U.S. policy and international law, though as earlier sections of this chapter have shown it is not an entirely new perspective. It also exposes the rigidity of U.S. policy as something rather undemocratic if the only definition of security and law enforcement is beyond review or redress by the citizens.

Even when law and policy are agreed upon, their enforcement assumes the existence of organizations that are democratic, honest, and uncorrupted. This of course is not always the case in newly democratic systems and especially where levels of human security and civic engagement are low. Once "corruption has become deeply entrenched, it is difficult to eliminate without damaging many of the healthy institutions of an already weak democracy" (INCSR, 2003). Although the overall plan supports the creation and strengthening of institutions like the courts, police, and due process, this language implies that their destruction may be an inevitable, necessary - and possibly tolerable - part of the process, as long as the goal of weakening the drug trade is achieved. The emphasis now is still on stopping supply and cutting off the flow of money through a concerted effort by a democratic coalition, but neither truly seems to have been achieved: users keep buying, and drugs flow from, through and to countries of all regime types.

\section{-- The Drug Trade's Adaptability: Obstacles \& Results --}

"As one of the countries most affected by illegal drugs, we cannot afford to give up any of the ground gained in the last decade" and yet what ground has been gained does not appear to be permanent (INCSR, 1998). With every counternarcotics success, the drug trade learns. Destruction of some cartels means those that survive become stronger, smarter, and more astute. The future of international efforts will rely on 
adaptability, flexibility, close coordination among governments, and "significant

resources" (INCSR, 2003). This may mean larger budgets approved by the U.S.

Congress or the military, and more cooperation and flexibility from other governments to follow U.S. funded policies and efforts.

Meanwhile, "the drug trade had little to celebrate at the end of the twentieth century" (INCSR, 1999). Previously, the 1997 report noted that intensified operations in Mexico and Central America moved more traffic to the Caribbean. Coca cultivation also shifted, but was not decreased or stopped just two years later; cultivation in the Andean region was down, but Colombia's was up by $20 \%$. This phenomenon, or balloon effect as it is frequently called, should not be surprising as a consequence of the eradication efforts in Peru and Bolivia. Colombian production increased and moved to areas beyond the control of similar efforts. At the same time, technological developments made it possible for more cocaine to be extracted from smaller amounts of coca.

The year 2000 was a year of "important accomplishments and serious challenges" for drug control (INCSR, 2000). Cultivation remained stable: down 70\% in Bolivia and Peru but up 11\% in Colombia. The total amount cultivated remained the same; in spite of efforts and shifts in focus, there was effectively no change from the previous year. In fact, cultivation continued to move into more remote, guerilla-controlled areas, certain to make future efforts at eradication increasingly difficult. And yet that same year it was declared that:

The coca crop has been contained: most of the big drug cartels have been fragmented, and the most violent of the drug bosses of the 1980s and 90s are either dead or in jail. The mechanisms for long-term international cooperation are in place and working effectively. The international drug control community can take pride in this progress (ibid.). 
If drug control measures have been so successful, why do drugs continue to be readily available? The answer appears not far behind these glowing reviews, but is still incredibly optimistic:

There is still, however, a long way to go. The drug trade has too much to lose not to exploit every opportunity to expand production and try to divide the international coalition threatening it. Yet it knows that it cannot survive a concerted, sustained campaign by a coalition of democracies individually determined to crush it" (ibid., emphasis added).

The 2005 report frequently mentions traffic in and through Mexico, indicating a shift from the Caribbean back to Mexican and Central American routes. A year later in the 2006 INCSR, Venezuela joined the list of countries failing to meet their counter-drug obligations. The failure of drug enforcement in Venezuela goes hand in hand with the continuing importance and use of trans-shipment points in the Caribbean. The report claims that the number of suspected drug flights from Venezuela to Hispaniola and other parts of the Caribbean more than doubled in 2005 and continued rising in 2006 (INCSR, 2007). The report also claims that the rate of U.S. cocaine consumption declined over the last ten years. It does not offer concrete numbers on this point and one wonders how true that might be since cocaine is still a major domestic drug concern and interagency data from 2006 (within the same report) shows that between 517 and 732 metric tons of cocaine left South America for the United States that year.

Controlling supply remains the number one strategy, but there is some indication that the tactics in use are not always universally accepted, especially eradication. The report suggests that longer term crop control should be developed along with alternative crop programs. It also recommends more attention to the processing and distribution 
stages through lab destruction and interdiction, only occasionally mentioning how poor

people involved at these stages might also be affected:

Destroying a lucrative crop, even an illegal one, carries enormous political, economic, and social ramifications for the producing country. It inevitably means attacking the livelihood of a large - and often the poorest - sector of the population. Democratic governments that take away vital income without any quid pro quo seldom survive for long (INCSR, 2003).

By extension then, an authoritarian government might have a better chance or be a better ally in the war on drugs. The suspension of civil liberties and democratic practices might be necessary for a government to maintain its control on drug policy. The report almost appears to contradict itself - drugs are antithetical to democracy, and yet it seems democracy may justifiably be put aside in order to control them.

\section{-- The Future of Interdiction in the Americas?--}

The September $11^{\text {th }}$ attacks and the ensuing war on terror have left most military efforts in the war on drugs in Latin America and the Caribbean far behind. The shift of emphasis to terror and the wars in Afghanistan and Iraq have left Washington's focus "muddled and disjointed" and "U.S. efforts have had no lasting impacts on the flow of illegal drugs into the country" (Bagley, 2007: 1). At the end of the time period under investigation here, there appears to have been no progress at all by this account. Indeed, even the budget proposed for the next phase "raises major questions regarding the future direction of U.S. drug control policies" (ibid.: 2). Once again, most money is directed toward interdiction of supply rather than "a comprehensive and balanced approach among interdiction, law enforcement, overseas programs and prevention/treatment programs" (ibid.). Equally troubling is the proposed reduction to the Andean Counter 
Drug Initiative to the complete exclusion of Venezuela - the source country of hundreds, if not thousands, of drug flights to the Dominican Republic and other parts of the Caribbean each year.

Bagley (2007) reports major decreases in U.S. military involvement in the drug war in Latin America and the Caribbean since 2001. These reductions leave significant gaps and undercut foreign efforts to control drugs. The U.S. has reduced the programs it introduced in the first place - cutting surveillance of Caribbean and Pacific cocaine smuggling routes by as much as $62 \%$ and reducing patrol boats by a third (ibid.). Bagley is correct when he says that this leaves places like the Dominican Republic, already faced with disproportionate traffic to enforcement capabilities, highly vulnerable. The Bush administration left drug policies in "disarray" which in turn offers "little hope of reducing the flow of illicit drugs into the United States in the foreseeable future" (ibid.: 4). This is ironic considering the outward looking policy the U.S. has always adhered to. Little money is allocated to demand reduction efforts yet the allocation for interdiction on the supply side is dwindling as well.

The FY2008 budget for Foreign Military Financing in the Dominican Republic was reduced by $100 \%$ - that is, eliminated entirely. At the same time, the USG thinks that demand for drugs in the Dominican Republic is increasing, especially since drugs are often used as payment. Demand reduction has strong support within the government and the public sector in the Dominican Republic. Survey data cited in the INCSR showed that only about 50,000 Dominicans used cocaine or marijuana in 1999. This accounts for less than one percent of the country's total population (approximately eight million that year) and shows a lower rate of use than in the United States. Unfortunately, the 2007 
INCSR also notes that there is little evidence to back up this assertion as few official surveys about domestic drug use have ever been undertaken in the country due to a lack of resources. Surveys have been carried out in the United States for years, though how reliable the data collected is and how accurately it reflects real rates of drug consumption is questionable. The surveys may grossly under estimate rates of use in the U.S. and the same is likely to occur elsewhere. Still, it is probably useful and necessary to undertake this sort of work especially as trafficking so obviously continues to affect local and international communities.

\section{$\underline{\text { Evaluation \& Conclusions }}$}

Cooperation abroad requires political will and the commitment of leaders, but this is a limited view: Leadership cannot work without structure and a culture of support. For this a country needs a populace without a need for drug revenue. The INCSR again and again acknowledges that there is "no commodity more lucrative than drugs." Money lost by traffickers in busts, even large ones, is but a small fraction of their total profits.

The FY01 budget for the USG international drug control was $\$ 18.8$ billion, the equivalent value of approximately nineteen metric tons of cocaine. The money made from drugs far exceeds the amount budgeted for their control. Yet the report has claimed that "the balance sheet...shows that we are on the right track. Sustained cooperation with our partners over the past decade has kept the drug syndicates constantly on the defensive" (INCSR, 2000). The following year, the total State Department budget for international drug control was $\$ 348$ million, or roughly the equivalent value of 3.5 metric tons of cocaine. Again, the amount of money used to fight drugs pales in comparison to 
the amount the drug trade has at its disposal, but we are repeatedly told these small expenditures are enough to make real progress.

At the same time:

Western industrialized nations, and particularly the United States, have had paramount influence in the creation and operation of the international drug control regime. The system reflects Western cultural, social, economic, and religious biases about which drugs require control and how stringent those controls should be (McAllister, 1994: 523).

These stringent controls in recent years have required the use of the military for enforcement. There are certain advantages to having the Department of Defense (DoD) in charge of anti-drug efforts. The DoD has experience working with foreign militaries, it has the ability to create coordinated and unified communications and intelligence systems, and it has all the related technology, especially after years of monitoring the skies and waters for Soviet vessels. The DoD can also use all of its existing personnel and equipment at a lower cost.

The ability to make use of local police and military personnel in the drug war outside the United States rests on the will of the local government. The U.S. can pressure but not direct all activities by governments abroad. Even so, "the United States, by insisting that the civilian police forces in these nations are incompetent to destroy what the United States itself terms criminal organizations, has telegraphed the message that militaries are more important than civilian institutions" (Mabry, 1994: 51). This kind of attitude is particularly troubling in a younger democracy like the Dominican Republic and one where the military and police have operated apart from civilian control in the past. Contrary to Mabry's assertion, civilian institutions have been the focus of reform 
efforts in the Dominican Republic, though more as a residual or cascading result of the drug war.

In U.S. circles "policy makers and negotiators have consistently not dealt with the problem in its entirety" (McAllister, 1994: 527). Regional approaches ignore the global nature of the problem, favoring supply control ignores the role of demand, and both contribute to balloon effects. The drug control regime carries the potential for success in international cooperation, but also has the potential for abuse and damage to national and international norms of jurisprudence and democratic governance. Extrastate forces could violate sovereignty, human rights, and fundamental liberties in the name of drug control.

The drug war is justified as another chapter in the U.S.'s book of anti-drug rhetoric, and is one more chapter in the history of a demonized "other." The outwardlooking strategy and characterization of the problem supports the idea of fighting and using the at-hand power of the military. Yet the full history of the coca leaf, its changing esteem and use among natives and settlers, and the growth and change in drug use and control regimes in the United States' own history should convince us that this war falls short of its own goals and real justice. 


\section{V: The Dominican Republic as Case Study}

This chapter brings our focus on the question of justice in the war on drugs to a case study of the Dominican Republic. By using the case study method, one can begin to see how the general questions regarding legitimate authority, just cause, proportion, necessity, and reasonable chance of success in the war on drugs manifest in a specific real-world setting. The case study also provides the opportunity to analyze the intersection of the international war on drugs and domestic processes of democratization. The details of one particular case study may prove informative for the broader discussion of law enforcement and democratic society elsewhere.

Scholarly attention, and much of U.S. policy, has focused on the primary drug producing areas such as Colombia, or producing and transshipment places like Jamaica (Jones, 2002). The Dominican Republic is now also regarded as a primary transshipment locale and has seen the growth of local drug gangs and violence, as well as increased domestic drug consumption (Griffith, 1997, 2000a, 2000b; Klein, et al, 2004; Rogers, 1999). In addition, the country has a close economic relationship with the United States and is a party to several bilateral and regional drug control agreements.

In writing about drugs in Colombia, Francisco Thoumi (1995) has found that a lack of regional integration, widespread inequality, and weak institutions within the country all contributed to the growth and profundity of the illicit drug trade there. A weak and delegitimized state and a general disregard for the rule of law made Colombia a low-risk location for drug production. All of these factors bear a striking similarity to conditions within the Dominican Republic: 
Several features of the Dominican Republic...make that country a prime trafficking candidate: proximity to Colombia, the Bahamas, Puerto Rico, and the southern United States; a long, often desolate border with Haiti; and poorly equipped police and military authorities (Griffith, 1997: 73).

In addition to geographical location, the expanse of forested or other less-inhabited land areas and the willingness of the migrant community to participate in the distribution network also make it more or less ideal for the drug trade. As I shall demonstrate in this chapter, there are even more conditions within the Dominican Republic that make it an optimal location for transshipment and that make control of drug traffic difficult or impossible. The collusion of government, police, and military officers in drug trafficking organizations has allowed them to flourish. At the same time, certain conditions within the Dominican Republic that are different from other countries in the region make the survival of the democratic state a possibility even in the face of rising crime.

The Dominican Republic appears on the list of major drug producing or transit countries, as well as the list of money laundering countries, in each of the International Narcotics Control Strategy Reports (INCSRs) between 1996 and 2007 examined here. "Intelligence and seizure throughout the region indicate that Dominican, Puerto Rican, and Colombian traffickers have made the Dominican Republic a major command and control center" (INCSR, 2000). The country's own National Drug Plan explains that its position as a command center is a result of its geographic location, but also notes the important role of the structured criminal organizations that operate in Santo Domingo, New York City, Boston, Providence, and elsewhere in the United States. Dominicans are the transporters of drugs to and from other locations, and only about $20 \%$ of the drugs that enter the country remain there. The Government of the Dominican Republic 
(GODR) also claims the drugs that do stay are frequently payment in-kind for transport services and contribute to increasing drug abuse and related crimes domestically. "Drugs is one of the main reasons for the rise in crime" over the last ten to 15 years in the Dominican Republic (Morgan et al., 2006: xii). The level of drug dealing in the Dominican Republic is high compared to other countries in the region while the capacity to deal with drugs and drug crime has been low.

Capacity is low because of the economic context in part, which has allowed drugs to infiltrate society at all levels. A study published by the Banco Central of the Dominican Republic in 1999 found that 15 to $20 \%$ of government and public workers fell below the poverty level. Poverty and inequality are, of course, not unknown in the Dominican Republic in general. The 1999 Banco Central study also showed that more than 2 million Dominicans were living below the poverty level (RD\$894 per person per month, currently about \$25 US), and that in 1998 the top ten percent of the population earned $37 \%$ of the national total, while the bottom half accounted for just under $20 \%$ of that total. The Dominican Republic is now a country of 9.5 million people, $15.6 \%$ of whom are unemployed and $42 \%$ of whom live below the poverty line (CIA, 2008).

Large numbers of Dominicans living abroad with weak loyalty to their host country make for an ideal drug distribution network. Income generated and sent as remittances back to the home country is also an incentive. Rogers (1999) has argued that dependence on these remittances from abroad has caused a number of people to abandon other forms of income generation within the Dominican Republic. That, combined with the loss of opportunity for jobs that pay well, particularly in connection with the growth of free-trade zones and export-processing zones (EPZs), creates an environment in which 
illegal practices can thrive. It is even worse when members of the enforcement bodies themselves become involved in many of these same illegal practices.

Indeed, data like that above reinforces the assertion that public employees are susceptible to bribes and corruption in its many forms. Additionally, Dominican nationals - especially fisherman recruited from local docks for small amounts of money are part of "go-fast" boat crews transporting drugs. Thus, transshipment is truly a transnational enterprise with economic benefits and risks for all those involved. What are small amounts of money for trafficking organizations are large amounts for the workers who accept them, which further underscores the economic appeal of trafficking and the inability of force alone to counteract it.

Rogers (1999) discusses several court cases which he says raise questions about the ability of Dominican institutions to combat drug traffic. There have been many offenders who escaped prosecution in the United States by returning to the Dominican Republic and avoiding extradition, or were not prosecuted in the Dominican Republic itself because they had economic and political clout. Cases like these provide justification for the widespread judicial and police reforms that have been taking place within the Dominican system since Rogers undertook his study. These reform programs have been implemented with the support of experts in the U.S. and will be the focus of the next chapter. In this chapter, I look first at Dominican history and experience with democracy, then at U.S. and Dominican cooperation and efforts to enforce drug policy at the international and domestic levels, and finally at some of the institutions charged with enforcing policy while preserving democracy in the domestic sphere. 


\section{$\underline{\text { A Brief History of Democracy in the Dominican Republic }}$}

The Dominican Republic is one of the least studied countries in the Western Hemisphere even though it is one that has the longest history of European settlement (Moya Pons, 1995). The country's history is extensive and the politics varied - as a colony, an occupied territory, an independent nation under authoritarian rule, and finally an independent democracy. It is this heritage, its influence on current dynamics, and the most recent experience of democracy especially that interest us in the present study.

The Dominican Republic has been independent since 1844, before slavery was abolished in the New World, and a century before the period of widespread decolonization in the Caribbean region. It is an example, along with Haiti, of "early national communities whose autonomous political history set them apart from the colonial societies of the surrounding islands" (Moya Pons, 1995: 10). Hartlyn (1998) argues that the pattern of politics in the Dominican Republic cannot be explained by Spanish Colonial Heritage alone, as many scholars like Howard Wiarda have done. He looks instead at the specifics of the post-colonial experience and shows a contrast to other cases such as Costa Rica where the path has been different. War, regionalism, lack of central authoritative elites, geography, ethnic factors, and militarization of the country all contribute to its struggle - and its "willingness to trade sovereignty for protection" on more than one occasion (Hartlyn, 1998: 55).

Frank Moya Pons (1995) has written a book that discusses the continuities, both economic and political, between the U.S. military government in the D.R. during the 1916-1924 occupation, and the governments that came after it. Trujillo and those who came after him are the most obvious examples of military involvement or militaristic 
elements in Dominican government, but even today we can find a certain acceptance of militarized governance within Dominican society. Even so, during the 1916 occupation "Dominicans did not like being governed by U.S. soldiers, as they had not liked it when they were ruled by Spanish soldiers at the time of annexation, by Haitian soldiers during Boyer's rule, or by French soldiers under the control of Ferrand" (Moya Pons, 1995: 327-328). Indeed, Dominican history is full of eras where rule came from foreigners. Dominicans often talk about their multiple dates of independence from these rulers, and resistance to external dictates has been imprinted upon many a Dominican mind when learning about their national history. In contrast to Hartlyn's analysis, Moya Pons asserts that over time, "Dominican politicians and intellectuals let it be known that they preferred a free country with rebellions to an occupied country living an imposed peace" (Moya Pons, 1995: 328). This may be echoed now where the country is free but dealing with the 'rebellion' of growing drug violence and with pressure from the outside from the U.S. and its increasingly militarized efforts to combat drug traffic.

\section{-- Occupation to Democratization --}

The Dominican Republic has experienced what Hartlyn (1998) calls neosultanistic or neopatrimonial rule, which is not directly related to Spanish colonial heritage. It is characterized by a history of initial poverty in the newly free state with weak economic elites, periods of war and economic devastation often establishing admiration for military strongmen, and U.S. occupation. The type of regime that results cannot legitimize or institutionalize itself in the long-run. These regimes are personalistic and tied to a specific leader. Rafael Trujillo, ruler of the Dominican Republic from 1930 
until his assassination in 1961, for example, lacked the kind of ideology based on religion or Marxism that other types of totalitarian regimes may have. Still, the respect for order, strong government, and economic nationalism produced by these regimes can engender public acceptance of authoritarian rule, making a transition to democracy for this type of regime "extraordinarily difficult" (Hartlyn, 1998: 59).

The U.S. occupation of the Dominican Republic during the early $20^{\text {th }}$ century (1916-1930) "helped establish a relatively effective national military institution where one had previously not existed and in which traditionally powerholders were weak" (Hartlyn, 1998: 38). This in part helped bring Trujillo to power. Support from the newly professional armed forces protected him against corrupt ruling elites and became a means for putting down rebellion later on. Trujillo came to power with 2,000 security forces. By 1955 the number had grown to 20,000. By 1965 it was 31,000 (ibid.). In this and other cases of neopatrimonial regimes, the military is established as a political player and a "personal instrument of the particular ruler, rather than... a national institution" (ibid.: 61). Civilian control of the military was non-existent and, again, difficult to establish with the transition to democracy.

The occupation did have some positive effects. The highway system was completed in 1924, creating links between the capital and the three major regions which helped "initiate the political unification of the country" (Moya Pons, 1995: 336). There was also an emphasis on education and sanitation within the military government. "From then on, to govern became synonymous with construction so that a good government was measured in terms of the construction of public works that it accomplished" (ibid.: 337). This is an interesting point in light of the controversy that surrounds President Fernández 
and the metro construction project in Santo Domingo. Many areas of the capital underwent renovation while the new train system was built, but there have been numerous complaints about the costs and potential benefits from such a project (see Lacey, 2007). The main complaint has been that money could provide for other more basic needs, such as water and electricity. In the summer of 2007 while I visited the capital city, several urban neighborhoods were without water for the duration of my twoweek trip. While the metro project is likely to have positive effects in the long run by alleviating traffic and providing an inexpensive means to bring people to and from work, the sentiment equating good government with construction does not appear as clear-cut as Moya Pons suggests. Measures of good government can also be based on public opinion surrounding institutions, such as the military and police, especially where civilian control has been limited.

The occupation in the early $20^{\text {th }}$ century also had its downsides. The general population was completely disarmed, giving advantage to the national police who were specially trained in repressive measures and not necessarily under the control of others in the population (Moya Pons, 1995). By 1924, the government was administered by civilians but the country was still a U.S. protectorate:

The Dominicans had learned that the center of political power in the Caribbean was in Washington and that the Dominican Republic was in the orbit of U.S. interests. From this time on, the exercise of sovereignty would be understood by Dominican leaders as always conditioned by U.S. foreign policy (ibid.: 339).

The post-occupation era was marked by prosperity and freedom, as well as rapid modernization, but it was also a time of regression to caudillo-style politics where party politics were a vehicle for personal ambitions (ibid.). Congress passed an extension on 
terms, and parties found other ways to share the spoils of government among themselves, while the U.S. was beginning to move away from direct occupation as a policy.

"For the first time in Dominican history there appeared to be a government capable of both keeping order and of maintaining civil liberties" but re-election campaigns and party divisions began to erode the government (Moya Pons, 1995: 350). The Chief of the army - Rafael Trujillo - took an interest in politics and was encouraged to have a political role as rival to the successor of President Vasquez. Vasquez was in illhealth and trusted Trujillo. Trujillo used this trust, and his power and influence within the army, to make his way into the presidency.

With Trujillo in office, Santo Domingo began a transformation into Ciudad Trujillo, which made it the center of administration as well as industry and commerce during the post-WWII era. Immigration from the interior increased significantly as well. In $1920,84 \%$ of the Dominican population was rural. In 1960 it had decreased to $60 \%$ (Moya Pons, 1995: 376). Trujillo's legacy was "a dualist economy with a very poor, large working and peasant class, and a total lack of democratic institutions" (ibid.: 379 ). Poverty levels continued to rise after Trujillo, especially during the 1980s under Balaguer. In 1984, 1 million Dominicans lived below the poverty level. Just five years later in 1989, the number was more than 2 million, or $57 \%$ of households in the country (ibid.: 434).

In the post-Trujillo era since the 1960s, pluralism has increased in the society through unions, political parties, schools, news media, and various other types of organizations, and yet caudillismo still characterized the country's institutional life. "Dominican political culture continues to be dominated by caudillismo and personalism," 
which would appear to be a difficult context for a new democracy to emerge (Moya Pons, 1995: 436). According to Hartlyn, the necessary conditions for a transition to democracy, as laid out in the academic literature, were virtually non-existent after Trujillo (see Haggard and Kaufman, 1995; Linz, 1978; O’Donnell and Schmitter, 1986). There was no clear path for succession within the outgoing government, and no truly organized opposition with a single popular leader. The election of Juan Bosch in 1962 was remarkable but the subsequent overthrow of his government and breakdown of the system was not surprising (Hartlyn, 1998; see also Lowenthal, 1972; Palmer, 1989). Hartlyn refers to this period as the first failed transition.

The coup overthrowing Bosch, followed by civil war and U.S. intervention in 1965, was then followed by "extrication elections" in 1966 (Hartlyn, 1998). This represents the second failed transition. Joaquin Balaguer was elected democratically, though how free and fair the elections actually were is a matter of debate, more so than for the Bosch election in 1962. The United States had a preferred candidate this time, and a policy where supporting democratization was secondary to other concerns like preventing the spread of communism in the region (Chester, 2001; Hartlyn, 1998). Hartlyn (1998) condemns the U.S. intervention as "truncate[ing] a popular rebellion and help[ing] polarize the country politically, flaming disbelief in democratic procedures and ultimately ushering to power a close collaborator of Trujillo" (97). The U.S. previously did not stop the overthrow of Bosch in 1963 to preserve democracy but inhibited consolidation by not allowing the Dominican Republic to follow its own path even if it were a messy and violent one - through 1966. Balaguer was elected but led the country in an authoritarian manner from 1966 through 1978. He curtailed civil and 
political liberties, and most of the political opposition was harassed by the military into abstaining from participation in elections. The neopatrimonial character of Dominican government had been altered by the constitution adopted under Bosch in 1963, but was again altered in 1966 so as to allow enhanced powers and unlimited reelection for the president. The military never became Balaguer's personal instrument as it had been for Trujillo. After the military overthrow of Bosch, Balaguer had reason to fear a threat from the armed forces, which were clearly a political entity and not under the direct control of the civilian government. He was able to court their favor by remaining anti-communist and by largely ignoring repression and corruption within the ranks. At the same time, he was able to dismantle some military conspiracies against him.

A successful transition to democracy did not occur in the Dominican Republic until 1978. It came about based on a number of converging factors: an economic slowdown, the growth of an organized opposition (in contrast to the Trujillo years where none had been allowed to exist at all), international and U.S. interest in democracy and human rights, and Balaguer's physical decline, particularly his failing eyesight (Hartlyn, 1998). Bosch had left his party, the PRD, which was the largest and most organized of the opposition parties. In his place was Gúzman, his former vice-president, an antiTrujillista and a moderate alternative candidate.

The PRD ran a successful mobilization campaign and won the election "convincingly" which led to a cautious transition from above - Balaguer was able to maintain a majority in the senate through some manipulation of congressional votes while handing over the presidency to Gúzman (Hartlyn, 1998: 120). In spite of this compromise, some effort toward a coup was made by the military, though it was mostly 
uncoordinated. It was uncertain whether Balaguer actually would step down and if the military would hand over power to the new leader. The time between the election and the inauguration was tense, but international pressure and attention from watchdogs helped the transition succeed.

The period after 1978 was a time of optimism for consolidation, but also one marked by additional "missed opportunities." It was a period of "juxtaposition of socioeconomic change and political blockage” (Hartlyn, 1998: 134-5). Hartlyn argues that neopatrimonialism is path dependent and reinforced by high inequality and low levels of political or civic organization. Where there has been a lack of independent organization and civil society, there will be little experience with democracy for new associations and organizations to draw upon. A similar situation will exist for the opposition - they will have little experience with moderation as opposed to revolutionary tactics. The practice of democratic power sharing and compromise in policy making after a transition to democracy occurs will have to be learned and may create the potential for instability and breakdown. From 1960 to 1990 the Dominican Republic experienced increasing urbanization, a move away from agriculture to tourism and EPZs as the main sources of income, and increasing migration and remittances, especially during and after the debt crisis of the 1980s. This period saw an increase of women in the work force, especially in the EPZs. But poverty persisted even in the midst of this growth.

The continuities of inequality and low organization allow for "continued vulnerability to neopatrimonial claims" (Hartlyn, 1998: 145). Survey data from the 1990s show "sufficient attitudinal support for authoritarian and neopatrimonial practices" in government (ibid.). On the plus side, the state has been less able to abuse its resources 
since international factors have become as influential as state economic policy because tourism and EPZs connect state interests to those of international actors.

During the same period the role of the military in politics decreased as the climate of violence and support for intervention also decreased, although this was not achieved through professionalization or democratic control over the armed forces. The military instead became top-heavy as leaders promoted those who were loyal to them. At the same time, low wages meant high rates of corruption, especially during the mid-1990s (Hartlyn, 1998).

Factionalism within the leading opposition party (PRD) and traditional opposition to presidential reelection in part allowed for Balaguer's return to office in 1986, where he stayed until 1996. The years 1978 to 1996 then were not a sharp break with the political past. Elections between 1982 and 1994 were "crisis ridden" and symptomatic of the relative newness and problematic nature of Dominican democracy, but they also "generated increasing pressure from a variety of actors for changes" (Hartlyn, 1998: 223). Electoral reform came in 1990, and constitutional and legal changes in 1994, all of which influenced the election in 1996, "whose outcome marked a sharp contrast with previous electoral processes and represented a new opportunity to break with the country's neopatrimonial patterns" (ibid.).

Specifically, in 1996 Balaguer was not a presidential candidate for the first time in 30 years. Two important measures had also been introduced (or reintroduced) into the electoral process: a prohibition on immediate reelection, and a second round vote should no candidate receive more than $50 \%$ of the votes in the first round. The 1996 elections thus marked a new transition "rais[ing] hopes in the Dominican Republic for a more 
regularized and formally institutionalized regime and...a more democratic regime as well" (Hartlyn, 1998: 273). Subsequent chapters are devoted to showing whether these hopes have been realized in the face of a growing drug and crime problem.

The Dominican Republic has made progress towards a citizenship democracy but has farther to go. The system is less personalistic and more institutionalized than previously but still may not be totally characterized by a respect for constitutional and legal norms. We may not be seeing a personalistic or charismatic leader taking on a patrimonial role as in other nations in Latin America, but there is still the potential for corruption and abuse of power by the military, police, and others within the government, and for a return to authoritarian measures if deemed necessary.

\section{$\underline{\text { Dominican Democracy \& Institutions }}$}

If drugs are affecting democracy and democratic institutions in the Dominican Republic, it is important to understand what those institutions are and how they function in order to gauge the extent of the problem. This section offers a brief overview of some of the history and structure of the Dominican constitution and various institutions within the system of justice. The final section of the chapter will return to this topic and discuss some recent research on attitudes toward democracy and institutions among the Dominican population.

\section{-- Dominican Institutions --}

From the time of Rome, there have been primarily two kinds of penal systems at work in the western world: accusatory and inquisitive. In the first, a judge serves as an 
arbiter between the parties, each of whom argues a case. In the second, the judge acts as an investigator and makes a ruling in the matter based on his findings. Until the enactment of recent reforms and changes, the Dominican system was a mixed one similar to those in France, Haiti, and Costa Rica. The constitution of 1844 established the state as the only authority able to punish crimes, with the Ministerio Público (public ministry or public prosecution department) and Poder Ejecutivo (executive power) closely related. The president has the power to appoint most posts within the government, including those within the administration of justice and the judicial police (FINJUS, 1998).

The Procuraduría General de la República (Attorney General) also has roots that go all the way back to the constitution of 1844 (ONAP, 2004). Its purpose is to represent and defend the public interest as well as the interests of the state. Under the president, it is its own large branch that includes the courts and prisons in the country. The Dirección General de Prisiones even has the same web address.

The Consejo Nacional de Drogas (Nacional Drug Council or CND) was established by law in May 1988. Its primary function is to design and implement national policy against the consumption, distribution, and trafficking of drugs. The CND is under the power of the executive. The Dirección Nacional de Control de Drogas (Office of National Drug Control or DNCD) was first established in 1959 and then reestablished in 1988 by the same laws that gave us the CND. Its objective is to prevent and punish the consumption, distribution, and illicit traffic of drugs and controlled substances in the national territory. Essentially, the CND designs policy while the DNCD carries it out.

The Policia Nacional (National Police or PN) are under the Secretary of State of the Interior and Police, which is part of the Presidential cabinet. The National Police has 
existed, in one form or another, since colonial times (though at one point it was technically the Guardia Nacional Haitiana). The name has changed several times during the $20^{\text {th }}$ century, and the security system was partially dismantled during times of U.S. occupation (ONAP, 2004). For example, in 1917 the national police force was renamed the Dominican National Guard, taking the place of the army, marine forces, and Republican Guard. In 1921 the name changed again to Policía Nacional Dominicana. During the Trujillo years, all police bodies were united into one national police force and placed under the direction of the Secretary of State for the Interior and Police. By 1959 new regulations established the police force's internal organization and set sanctions for lack of discipline or wrongs committed by members.

In 1965, Law 574 placed the PN under the control of the armed forces, even though Law 22 maintained it under the Secretary of State for the Interior and Police. During this period of civil unrest, Decree 111-90 created a subgroup of military electoral police for preserving and maintaining order during elections. Much later, Decree 906-00 in the year 2000 declared that it was in the national interest to reform and modernize the PN and created an executive commission (ONAP, 2004). Since then, the National Police Museum, Social Security Institute for the PN, and the Human Dignity Institute of the PN have been created. All are efforts to bring the police and community closer together and to show the police as an institution under civilian control. The museum covers the history of the police and serves to inform the public about the police and their role, thereby generating a better public perception. The Human Dignity Institute is especially concerned with professionalizing the police force and creating officers that respect 
human rights, civil rights, and due process. These police reforms come at a time of extensive change and reform in the system overall.

Returning to the court system in the Dominican Republic, accusatory systems put accuser and accused on equal footing before the law and are open to public oral arguments. Inquisitive systems are secretive, written, and uncontradictory, meaning a judge's word is final. The Dominican mixed system, derived from Napoleonic code, was complicated and did not necessarily judge the merits of an accusation impartially. One might argue that an accusatory system is far from perfect because it rewards the best argument but does not necessarily find the truth. One could also argue that while the inquisitive system appears to place emphasis on fact-finding, it relies on the integrity of a single judge to follow through and act impartially, which leaves much space and potential for unscrupulous behavior. Indeed, the public prosecution department could often be seen as an extension of the executive with no limits on the qualifications for appointment. The system could easily be used as an effective way of preserving the status quo and offering rewards and favors within it. As FINJUS argued in its 1998 report on the system, defense of the accused needed to become an integral part of the process from the beginning of every case. In a system like the one in the United States, one may obtain legal representation as soon as one is detained, which requires a fully compliant and welltrained police force as the first step in the judicial process. This type of system is in line with international standards for human rights. Reform efforts focused on creating this kind of system within the administration of justice in the Dominican Republic are some of many important changes that have been occurring in the country since the full transition to democracy in 1996. 


\section{-- Democracy: Rights and the Constitution --}

The Dominican constitution, reformed in 1994 and recently the subject of additional newly proposed reforms, contains what are known as derechos absolutos mankind's superior inalienable rights which are merely reaffirmed and made precise within a written constitution. Often called the rights of man, individual rights, fundamental rights, or human rights, they are contained within the Dominican Declaración de los Derechos del Hombre y del Cuidadano, which is similar to the Magna Carta or the Preamble to the U.S. Constitution. These rights "are expressly recognized, in one form or another, and with few fundamental differences, by all democratic constitutions" (Amiama, 1995: 61). Most of the fundamental rights discussed within the Dominican constitution are the same as those contained within the United Nations Universal Declaration of Human Rights of 1948 as recognized by “modern" nations (ibid.). One major difference among some democratic states is the existence of a death penalty, which in many states - including the Dominican Republic - is considered contrary to one's inviolable right to life. The death penalty has not been a part of the Dominican constitution since 1966.

The Dominican constitution provides that one's home and correspondence are private and inviolable, though this is a right that is not $100 \%$ absolute. The law sets out the procedures authorities must follow in order to intervene, such as obtaining warrants to search homes or confiscate correspondence. The constitution also allows freedom of assembly for peaceful purposes and licit ends. This is particularly important for the development of civic and community organization. As mentioned above, these rights are similar to those found in the constitutions of other democratic states. Of course the 
theory is often different from the practice, especially in places where the procedures are new or not well institutionalized. As more than one Dominican citizen has said to me in conversation, what is written in the books is not what is practiced by those in power. Police reform programs in the Dominican Republic are meant to address the gap between the ideals and the actual institutional practices that have been built over the years.

The constitution contains a right to individual security, which means freedom of movement, freedom from being detained or jailed without legal cause, and freedom from being tried twice for the same crime. The constitution also provides that no one can be punished for a crime without a public trial. Similar to habeus corpus laws, many would consider them important and fundamental rights. At the same time, when crime is rampant, there may be a tendency to overlook violations of these principles. Indeed, when the rhetoric of war is invoked to confront particular kinds of crime, protections contained within the constitution may then be suspended or even ignored. The next chapter will explore this further. I turn now to U.S. evaluations of the Dominican Republic and the implementation of drug policy there.

\section{U.S. Assessment of the Dominican Republic - The INCSR}

\section{-- International Cooperative Efforts --}

"The Dominican Republic has historically been the primary beneficiary of U.S. military aid and training programs in the region" (Beruff and Cordero, 2005: 318). There is a strong relationship between the Dominican military and Southcom, and the Dominican Republic was the only Caribbean state to send troops to Iraq (ibid.). With 24,500 troops total, the Dominican military is one of the largest in the Caribbean - but it 
is still quite small compared to U.S. forces. The joint operations described below involve many U.S. troops and equipment. The Dominican government oversees the DNCD which has been viewed by some U.S. officials as "the model counter-narcotics force in all of Latin America" (Rogers, 1999: 198). This praise comes in spite of evidence of nepotism in assigning individuals to certain posts and that members often receive kickbacks. The majority of the DNCD's members come from the armed forces, police, and justice system and work closely with the DEA and U.S. Coast guard.

A variety of Coast Guard operations take place in the Caribbean each year. For example, Caribe Venture is a recurring series of operations in which the Dominican Republic is a party. Caribe Venture "extend[s] legal authority to law enforcement officials of other nations that permit entry and pursuit of suspects through sovereign sea and air space" (INCSR, 1997). Operation Halcon is a counterdrug and alien migration operation conducted by the U.S. and Dominican Coast Guards. The DEA Caribbean Field Division has set up the Unified Caribbean On-line Regional Network (UNICORN) which includes the Dominican Republic (INCSR, 1998). It is a computer and internet program for information sharing among participating countries.

The United States Coast Guard (USCG) conducted Operation Genesis in Port-auPrince and Santo Domingo to foster cooperation between Haitian and Dominican law enforcement. This operation led to the arrests of 126 people (INCSR, 1998). In 1998, Operation Frontier Lance, a surge operation south of Hispaniola, was conducted by the USCG with shipriders from Haiti and the Dominican Republic. This marked the first time that the USCG conducted counterdrug operations from a foreign base in the Dominican Republic. 
Coast Guard operations Caribe Venture, Genesis, Frontier Lance, and Halcon continued during 1999, and a number of U.S. Coast Guard officers were posted at the embassy in the Dominican Republic. The maritime law enforcement training team visited the country twice during the year, and two patrol boats and a buoy tender were transferred. The Coast Guard operation Caribe Venture continued in 2001, but the second of two planned operations was cancelled once U.S. maritime focus turned to homeland security in the wake of the September 11, 2001 attacks.

The USCG continued Operation Caribe Venture in 2002. A military and law enforcement exercise known as Sorpresa Nocturna took place in June of 2002. The largest operation of its kind ever conducted in the history of Dominican law enforcement, it included cooperation with the U.S. and Haitian police. In March of 2002 a proposal to establish four regional Centers for Drug Information (CDIs) was approved, with one to be located in Santo Domingo. These centers are to promote information sharing among law enforcement personnel across forty-one countries. In 2003 the CDI in Santo Domingo became fully operational. The CDIs "provide the law enforcement personnel of 41 participating nations with the capability to share drug-related tactical and investigative information in a timely manner" (INCSR, 2004). This sharing is made possible through 131 computers.

The USCG conducted Operation Steel Web in 2005, covering transit lines in and around Caribbean waters, and in 2006 the operation was "continually evolving to reflect changes in drug trafficking trends" (INCSR, 2007). Operations continued with an emphasis on the north coast and the border with Haiti, though some efforts were made to 
stop airdrops and boats in other remote areas. All operations clearly show a constant U.S. presence in the region and influence over Dominican drug control.

The DNCD and DEA broke up two large smuggling rings - one of them connected to a man with large land holdings along the Haitian border. "Gang violence and settling of drug-related scores, especially in northern cities, were subjects of frequent headlines in the Dominican Republic press" (INCSR, 2005). Prior to 2005 this new topic had not been mentioned in the reports during the time period covered here and it may be an indication of things growing worse before they get better, as stricter enforcement of drug laws creates fear and uncertainty for those involved in drug traffic, producing territoriality and competition between them. At the same time, increased enforcement came while the economy was still attempting to recover, all types of crime were on the rise, and drug syndicates had more control over certain parts of the country than did the state itself. Government efforts to address the surging rates in crime and reassert control at the local level are discussed in more detail in the next chapter.

\section{-- Customs and Border Controls --}

Continuing with the theme of U.S. involvement in Dominican drug control matters, two U.S. customs officials came to the Dominican Republic in October of 1998 for training and exercises in land border interdiction through the newly created and funded Dominican Anti-Crime/Counter Narcotics Border Unit. Another U.S. Customs training team visited in 1999 for land border interdiction. According to the report, the training resulted in creating a sense of teamwork, an improved understanding of the mission and its scope, and greater professionalism and ability to perform searches and 
data collection among Dominican personnel. A fourth border control unit was opened along the Haitian border. With USG assistance, GODR planned to increase the number of dogs and handlers at the border for the following year.

In November 2000, the GODR signed a four-year agreement with the USG to allow US aircraft to fly in Dominican airspace in pursuit of smugglers. The GODR in 2000 also added three land control units to the four already operating on the Haitian border. In 2001, the Dominican Republic initiated bilateral intelligence sharing and interdiction efforts with Haiti. The DNCD and CND also began an initiative to computerize and track all seizures of assets in drug cases. The Dominican Senate passed new anti-money laundering legislation, which U.S.-funded programs helped draft and promote. The economic climate during 2003 was precarious with the collapse of BANINTER, the third largest Dominican bank, which increased the difficulty of implementing the new anti-money laundering laws.

The DNCD saw an increased number of seizures during 2001, including almost daily body-carried drugs in mules, indicating a large number of mule operations. The DNCD continued to focus its efforts on the north coast and the border with Haiti. Also in 2001, a U.S.-funded readable passport system was installed and immigration computers purchased for the airport in Punta Cana. Counternarcotics and explosives detection canine units were expanded to all international airports and seaports in the Dominican Republic, with U.S., Dutch, and other international assistance (INCSR, 2005). The DNCD was reported to be upgrading its equipment, training more personnel, and developing software as part of a multi-year, USG-supported effort to share data and information among Dominican law enforcement agencies. 
The 2003 INCSR noted that about $8 \%$ of the cocaine destined for the U.S. comes through Hispaniola, but that there had been a decrease in drug smuggling via ferries to Puerto Rico thanks to the newly established counternarcotics canine units placed at the Santo Domingo terminal. However, the report also notes an increase in the use of jolas, or illegal migrant boats, for transport of drugs between the islands. In spite of all the operations and programs described above, drugs continued to move through the region. The next section briefly presents some numbers related to interdiction efforts in order to illustrate some of the effects of the programs, as well as the resilience of the trade.

\section{-- Numbers --}

As noted previously, the amount of money allocated to interdiction often pales in comparison to the value of the drugs intercepted. Between 1988 and 1997 the USG gave about \$3.9 million in counterdrug assistance to the Dominican government. The number of arrests for drug-related offenses in 1997 was 1481 (INCSR, 1997). Two years later the GODR allocated \$3.5 million toward counternarcotics and an additional \$646,000 was allocated from the USG (INCSR, 1999). Through December 2000, the DNCD seized 1,270 kilos of cocaine and made 4,625 drug-related arrests (INCSR, 2000). In 2000 the USG and GODR signed letters of agreement totaling \$1.5 million for narcotics affairs.

The DEA in the Dominican Republic seized 186 kilos of cocaine and arrested two Dominican nationals in 2001(compared to 1237 kilos seized in Jamaica the same year). In 2001, the DNCD made 3708 drug arrests, 3496 of which were Dominican nationals -fewer than in the previous year. The increase in heroin seizures again showed a large number of mules bringing bodily-carried drugs through the nation's airports. 
The DNCD seized 1.1 metric tons of cocaine in 2002 (INCSR, 2003). The USG claimed that significant seizures were made on land and in the big cities, while seizures at the border were limited during 2002. The number made at airports was high even though the amounts seized were small. The report also discusses the growing local market and drug consumption by tourists as important factors driving the trade. There were 3929 drug-related arrests (3692 of which were Dominican nationals) during 2003, with fewer foreign arrests than in previous years. Local law enforcement was either acknowledging the problem is local as well as international, or they were reluctant to arrest tourists who bring significant income to the island nation.

The DNCD reported 3305 arrests in 2004; 3150 of these were Dominican nationals, with 82 fewer foreign nationals arrested than the previous year. Of all heroin seized for the year, $85 \%$ was taken in airports, but only $12 \%$ of all cocaine seizures were made in airports. The DNCD increased seizures and set records for the amount of heroin (39kg) and ecstasy (259,627 units) confiscated during 2005, the latter of which was found in bags abandoned at the airport. This may not necessarily have been the result of intelligence but could be the result of better and more consistent screening procedures. The largest seizures of cocaine were made from cargo containers destined for New York. In 2005, 3330 drug-related arrests were made, 3206 of which were Dominican nationals. There were two joint DNCD/Dominican Navy/USG operations during 2005, one of which resulted in the interdiction of $2,000 \mathrm{~kg}$ of cocaine. Five metric tons of cocaine were seized, and a new record for a single seizure was set in September 2006 when 2.5 metric tons were taken (INCSR, 2007). The DNCD made 8,809 arrests, 8,563 of which were Dominican nationals. These numbers show a huge increase over previous 
years, more than double in fact. This is not necessarily in indication of more individuals involved in drug traffic, but may instead be the fruits of better intelligence, interagency cooperation, and law enforcement capacity. If these programs are indeed working, we should expect to see similar results in future reports. The next chapter explores whether or not other reports and surveys corroborate the short-term success of capacity improvement efforts that support the numbers seen here. Success from the U.S. point of view places more emphasis on the technical aspects of interdiction and the resulting statistics, while the Dominican approach has been more all-encompassing of other structural factors.

\section{-- Extradition and Prosecution --}

The USG sees improving local justice systems as central to bringing drug criminals to face charges in the U.S. courts. Extradition agreements have been important elements of U.S. drug policy and enforcement plans elsewhere. In the Dominican Republic, a 1969 law prohibits extradition but executive decree allows for exceptions. It may also leave the executive open to criticism, particularly from those who believe extradition should be part of a judicial process. At the beginning of the time period under investigation here, the USG still hoped to sign a bilateral treaty with the GODR for extraditions. In spite of this prohibition and lack of a treaty agreement, several Dominicans are extradited to the U.S. on drug charges every year.

In 1997, two extraditions were authorized through the executive authority of President Leonel Fernández. Nine people were extradited to the U.S. in 1999, though the process was still not regularized and was subject to political influence. In 2000, the 
INCSR notes how the DNCD electronic surveillance unit became advanced enough that evidence gathered could be used in U.S. courts, which is likely to support increased extraditions and stronger cases against offenders in the U.S. but not the idea of a stronger domestic court system capable of handling similar cases with the same kind of evidence. For that same year, there were four Dominican nationals extradited to the U.S., and fourteen U.S. citizens and other foreign nationals deported or expelled from the country.

The government of President Hipólito Mejía pledged its cooperation with the USG and published the National Drug Plan 2000-2005 in August of 2000. Fifteen Dominican individuals were extradited to the U.S. from the time Mejía took office in August of 2000. In 2002, the DNCD extradited seventeen more people to the U.S., and made twelve arrests in response to requests. The National Police also located fourteen other individuals for extradition. The USG even provided partial funds to construct new cells at Najayo prison in order to house fugitives awaiting extradition. In other words, U.S. taxpayers paid to build more prisons abroad.

During 2003, seventeen Dominicans were extradited to the United States. In 2005 there were 33 extraditions of Dominican nationals, and 22 arrests and deportations to the U.S. of U.S. and third-party nationals. Of these 55 cases, 42 were drug related. At this time, judicial review was added to the process for extradition, making it "more objective and transparent” (INCSR, 2006). In 2006, 26 Dominican nationals were extradited to the United States. There were 21 arrests and deportations of U.S. and other third-party nationals. Of these 47 cases, 38 were drug related.

The number of Dominican nationals extradited to the U.S. indicates the extent of U.S. official belief in the inability of the Dominican system to adequately prosecute drug 
cases. The question of jurisdiction remains and one might wonder what sovereign authority the U.S. has to try Dominican offenders in Federal courts. We could ask if justice might better be served in an international court instead, or a neutral third-party court for these kinds of cases, particularly when one remembers the emotion and rhetoric that has been used to justify the war on drugs. A fair trial is not necessarily ensured on either side.

\section{-- Domestic Institutions: Reform and Evaluation of the Police and Justice Systems -}

In the case of the Dominican Republic, "endemic corruption among judges, prosecutors and law enforcement" is a major concern for the time period covered by this study (INCSR, 1996). In 1996, the incoming Fernández administration had no "master plan" and many "unresolved, long term narcotics related issues" to deal with (ibid.). The country's long coastline has frequently allowed small vessels to depart and reenter freely without reporting to Dominican authorities, and the drug traffic problem has been exacerbated by a "lack of consistent and honest customs and police controls" (ibid.). The country had both a problem of permeability to crime and a lack of adequate regulation and enforcement overall.

The Dominican border with Haiti has always been an issue for law enforcement. It is patrolled by the army which is "not effective in combating crossborder narcotics traffic" (INCSR, 1997). While many seizures are made at airports, there is inadequate counternarcotics coverage of the coastline and interior of the country. The focus of interdiction efforts has remained on drug transit routes in the waters of the north coast and along the border with Haiti. Some research indicates and Dominican news reports 
confirm that large quantities of drugs move through the eastern and southern coast areas instead, and yet little attention to these areas is mentioned in the U.S.'s own evaluations. Recent news reports in the Dominican Republic have shown drug traffic and official collusion are heavily entrenched in Baní, the capital of the Peravia province in the region to the south and west of the capital city (DR1 Daily News, August 8, 2008). This is another example of the balloon effect and how the drug trade can find a way around any successful counternarcotics strategy.

The Dominican Republic was reported to have a weak judicial system, but one that had begun "promising reforms" in 1997 (INCSR, 1997). A Memorandum of Understanding was signed by the DNCD and the Dominican Attorney General so that prosecutors would become a part of all initial investigations in drug cases. The intention was to create continuity in the prosecutors' involvement from the beginning to the end of each case, thus helping to ensure that prosecutors had knowledge of all aspects of the cases to which they were assigned. The increased involvement of prosecutors at all stages may also have had the effect of creating a certain level of oversight between the two institutions.

Still, "corruption and inefficient administration of justice let more than 100 people off the hook in 1997" (INCSR, 1997). A new supreme court convened in August of 1997 and began the dismissal of corrupt and incompetent judges from the lower courts. The USG began to help the GODR to "design and fund a pilot program to modernize and improve criminal and civil courts in the city of Santo Domingo" which was to be used as the basis and model for future reforms elsewhere in the country (ibid.). Funds from the U.S. were also used for the creation of an anti-corruption unit to investigate high officials 
and end the impunity many had enjoyed for years. These statements in the report about the impunity traditionally enjoyed by high ranking officials seem to contradict other statements that no evidence existed to link government officials to drug traffic or money laundering. Drugs and drug money were not accepted by the government as a matter of policy and no officials were indicted for drug corruption during 1997, but a lack of evidence of drug corruption does not necessarily mean it did not exist. At that point in time there seemed to be no proof one way or the other.

Two years later the Dominican Republic still lacked a coordinated national strategy although the CND had drafted an official National Drug Strategy (INCSR, 1999). The corrupt and inefficient judicial system allowed for the dismissal of "a significant number" of drug offenders (ibid.). The CND held seized assets worth over $\$ 40$ million but had no mechanism to manage divestment. The DNCD worked closely with the DEA but could have benefited from "greater inter-agency cooperation, especially within the Dominican military" (ibid.). The GODR was in the process of developing an anti-corruption bill, and the DNCD implemented drug testing for new employees and random tests every six months. The GODR also created two new units for "sensitive investigations of prominent international narcotics organizations" within the country and submitted personnel to vetting by the USG (ibid.).

Institutional corruption and the reform of prosecutorial and judicial systems remained the primary concerns of the USG, after cocaine traffic and money laundering. Unfortunately, "the Department of Justice put a hold on its...program to enhance criminal investigation techniques until the National Police implement adequate safeguards for protecting human rights and due process" indicating not only that the 
National Police did not uphold the democratic processes the USG finds so integral to the war on drugs, but that the efforts to improve investigations and bring offenders to justice were not achieved because of these shortcomings (INCSR, 2000). The Dominican government worked during 2000 to strengthen a 1979 law requiring all senior appointed officials, civil service employees, and elected officials to file financial disclosure statements. Those from all judges were published online. This online financial disclosure for justices continued but in 2001 no system to verify the information had been put in place, nor were there any official sanctions for false statements.

The United States' goal is to help institutionalize judicial reform and good governance in the future for the Dominican Republic. With U.S. support, the GODR revised criminal procedures and began a change in the Dominican judicial system from the Napoleonic inquisitorial system to an accusatory system more like the one used in the United States where oral arguments are made before a judge and jury, rather than the presentation of a set of evidence for review by a judge alone (INCSR, 2003). The GODR began training in 2003 for the implementation of this newly revised criminal procedures code (INCSR, 2004). The U.S. provided training to prosecutors and investigators with the hope of creating professionalism and sufficient preparation for when the new criminal procedures code became effective in 2004 . How much time might truly be needed to meet the demands of these changes remains to be seen and is part of the short-term evaluations presented in the next chapter.

In 2005, the Dominican Attorney General pursued some anti-corruption cases, and implemented competitive civil service recruitment of prosecutors. The latter is of particular interest since these positions were previously political appointees. The USAID 
criminal justice and transparency program claimed results in the form of "faster case processing, decreased pre-trial detention, availability of public defenders and prosecutors 24 hours per day, and positive change in the justice sector's attitudes toward presumption of innocence of the accused" (INCSR, 2006). USAID also assisted the Public Prosecutors office with the development and implementation of policies and procedures for evidence preservation, and asset seizure and maintenance.

It is too early to evaluate the results of this particular program completely. My observations of the police conference in June 2007 are that some positive steps have been taken, in addition to the number of young new police recruits graduating from training academies. It is likely there are still remnants of the 'old' police culture that will take time to be replaced by the 'new' one. The police institution still maintains many career officers whose influence over the rank and file is just as strong as any new indoctrination will be.

"Deaths as a result of police involved shootings have declined considerably due to a new training curriculum for basic police training development and implementation in 2006" (INCSR, 2006). Details about this new training curriculum are not provided. At the same time, new training goes along with efforts to eliminate impunity, and other reforms to the institution as a whole. New training and teaching may eventually re-create the institutional culture of the Dominican National Police as more and more new officers come into the system. Whether there are any lasting effects will depend on how long their training will hold up to the old practices and attitudes of seasoned officers.

The GODR made efforts to reduce the influence of the drug trade within the judicial system through the removal from office of at least 24 judges during 2006 "for 
improperly handing out favorable sentences to known narcotics traffickers" (INCSR, 2007). But corruption and the influence of drugs were still a problem, especially as “favoritism among the Dominican Republic's law enforcement elite leads to frequent changes in office among its command-level officers, retarding any progress made with prior officials" (ibid.). The culture of the institution again appears stronger than its new regulations.

During 2006, 100 newly hired prosecutors graduated from the National School of Public Ministry. The United States FBI also taught basic Crime Scene Investigation to a mere 30 National Police officers. The Law Enforcement Development Program, implemented by NAS, restructured the National Police's Internal Affairs by the end of 2006 and terminated approximately 60 police officers who tested positive for drug use (INCSR, 2007). This may seem a simple and logical method but it is often these basic procedures that have been neglected within an institution whose history has made it a tool of a particular leader rather than one under civilian control with respect for the rule of law.

\section{$\underline{\text { Democracy and Public Opinion }}$}

This study is interested in the connection of drug traffic, drug use, and related violence and enforcement concerns to the functioning of the democratic system. For the last 30 years, the Dominican Republic has been a relatively stable democracy in spite of its "institutional deficiencies and socioeconomic problems" (Morgan et al., 2006: ix). But how well it functions and what the quality of that democracy is also depends on the 
population's own sense of what democracy is or should be. This section delves into a recent assessment of public opinion and evaluations of Dominican democracy.

The DEMOS survey data (compiled by the London-based think tank) used in the 2006 study by Morgan et al. is comparable across time, and the surveys, from 1994, 1997, 2001, and 2004, plus the authors' own Latin American Public Opinion Project (LAPOP) survey in 2006, make their results applicable to this dissertation. The DEMOS survey of political culture is the only one that has been systematically carried out over more than ten years that is available to researchers, and it is comparable to the LAPOP study used by Morgan et al. (2006). These surveys were performed in a variety of Latin American countries.

"In the last 15 years, the Dominican Republic went from being a country in which very few public opinion surveys were conducted, to one in which surveys are constantly being conducted" (Morgan et al., 2006: 10). Thanks to this new proliferation of surveys, a number of which are analyzed in the next chapter, we can begin to see a clearer picture of Dominican civic life. Survey data cited by Morgan et al. reveals that "the Dominican people are attached to democracy as a political system, on the one hand, and points to the problems ailing the system, on the other" (ix). Consistently from 1994 through 2006, most Dominicans think that corruption within the system is a serious or very serious problem. Many believe it is widespread throughout the country, though it tends to be more widespread in urban areas, especially Santo Domingo. The study claims that in spite of this belief, people have limited first-hand experience with corruption, and according to the LAPOP data, the Dominican Republic is among the five countries with the fewest people victimized by corruption. 
In spite of the perception of corruption, among the countries surveyed Morgan et al. (2006) "the Dominican Republic has the highest level of satisfaction with the efficacy of the current administration" (xii). At the same time, the survey data has to be understood in the socioeconomic context in which it was gathered. High support for and the popularity of the Fernández administration in 2006, compared to the previous Mejía administration, is in part the result of economic growth and low unemployment between 2004 and 2006 and after the banking crisis of 2003. Equitable distribution of this economic growth continues to be a challenge, as are other things such as the "electric energy problem, the giant stone in the government's shoe" (ibid.: 8). Government subsidies to energy are almost equal to the amounts spent on education and health care combined.

The survey shows a positive perception of the economic situation in the Dominican Republic during 2006, although criticism of government spending has risen by 2008 as evidenced by numerous opinion pieces and articles published in the Dominican press. Perceptions of personal finances were less positive. "Favorable opinions regarding how well the economy is doing and the provision of services are very important for the maintenance of institutional stability" (Morgan et al., 2006: 11). Police and security can be seen as a part of this provision of services, as is the administration of justice. Thus, the burden of the Dominican state to improve its institutions depends both on the economic feasibility of providing services through these institutions and the services themselves. In an environment where the institutions are seen as corrupt, and where the economy is failing for many, the expectations held for the institutions and their integrity can suffer. 
Most important for this dissertation is that the authors find positive attitudes toward democracy survive even during periods of incredible disorder or heavy reforms. The study claims that while one-third of the Dominican population could not define democracy in any specific way, two-thirds still said democracy is preferable to any other form of government. The public's understanding of democracy is often different from conventional meanings for the term in political theory, especially in the Latin American context where democracies may entail political rights but few social protections (Morgan et al., 2006). The LAPOP survey asked open-ended questions in order to capture these various conceptions of democracy. The answers were then grouped in to four categories. These are: Instrumental-utilitarian definitions with an emphasis on performance and benefits, and the association of democracy with well-being, opportunity, and growth; Normative-axiomatic definitions whose aspects are not tied to immediate and personal benefit and are more abstract such as freedom and free elections; Negative definitions which focus on the problems of democracy like disorder, crime, or corruption; and Empty definitions, all of which lacked any specific meaning of democracy at all.

The most popular conception of democracy given by those surveyed in the Dominican Republic falls into the Normative category, with $52 \%$ of the answers, followed by the Empty category at 37\%. Only $6 \%$ gave Instrumental/utilitarian answers, and only $4 \%$ were Negative. This result might be considered surprising taking into account the level of corruption within the country. One might expect to see more Negative answers, but perhaps the relative youth of the democratic system explains the higher number of Empty responses instead, as corruption within the system clearly predates democracy. 
More troubling is the fact that the most popular answer given to the question "what does democracy mean to you?" was that it does not mean anything (33\%). This might simply be an indication of generalized apathy toward the political system, or a reflection of the short length of time democracy in the Dominican Republic has had to provide any kind of benefit to most of its citizens, the older generations in particular. These numbers might also run parallel to the Newlink surveys covered in the next chapter where high levels of respondents did not give answers at all or said they do not know.

The survey shows a positive correlation between wealth and normative conceptions of democracy, and a negative correlation between wealth and empty conceptions. The same tendencies hold for education and age, though to a lesser degree after age 45 . In other words, the younger, poorer, and less educated a person, the more likely they are to disregard democratic norms. We might extend this to respect for the rule of law, including rights of criminals on one hand, or even perhaps a willingness to be involved in drug traffic and criminal activity on the other.

Morgan et al. (2006) propose a possible link between legitimacy and tolerance in the system, and the prevailing concept of democracy in a given society. They argue that "it can be assumed that if political legitimacy and tolerance do not have a normative basis, then attitudes might be very fragile and ephemeral, especially in the face of the economic and political difficulties of democratic systems" (25). At the same time, the study suggests that since the majority has normative or no specific conceptions of democracy, versus negative or instrumental, this is a reason democracy has been maintained despite economic and institutional problems. Whether we accept the time frame used by Morgan et al. of three decades of democracy or Hartlyn's for only the last 
12 years, the expectation of tangible benefits within an institutional/utilitarian conception is not there and thus the public is not as readily disappointed by the system, nor is there a significant proportion of the population expecting the most from it but seeing the worst in it.

On the normative conception, the Dominican Republic ranks lower when compared to other parts of Latin America, but the authors suggest that:

The problem is that so many people do not know what democracy means. This suggests that greater civic education is needed for the public to develop a concrete idea of what democracy is, to identify when it exists or when it does not, and to be able to support it with knowledge and conscience (Morgan et al., 2006: 33).

In other words, the people who support extra-legal measures for dealing with criminals (see next chapter) likely do not have a real conception of democracy nor an understanding of their basic rights in the first place.

The Dominican Republic shows one of the highest levels of political tolerance and highest levels of support for the system, which are both necessary for stability. "The level of political and social tolerance is a good indicator of the level of the public's normative commitment to democracy" (Morgan et al., 2006: 35). These authors measure the acceptance of the rights of people who constantly criticize or disagree with the government. We could extend that to acceptance of the rights of people who are suspected of crimes and argue that normative democratic values also include the rights of the accused.

Morgan et al. suggest that public opinion is not the most reliable nor sole indicator of future stability, pointing out other factors that also have an influence, such as elites and the international context. In this case the international context of the drug war 
could be a de-stabilizing factor. According to the authors, the Dominican Republic has not had a crisis of stability since 1978, but U.S. policy would have us believe that the international drug trade is a serious threat to democracy in the country and elsewhere. The third wave of democratization roughly coincides with the growth of the international cocaine trade, and yet the governments of both Colombia and the Dominican Republic have survived so far. Survival of the state, though, does not necessarily mean security for all within it. In the next chapter we will look at the ways the Dominican Republic has attempted to improve security, public perceptions of security, and the influence of organized crime, corruption, and reform efforts on democracy and civil society.

\section{Conclusions}

The road to democracy in the Dominican Republic has been a long one, and recent literature and surveys suggest that a certain apathy toward democracy exists, as well as a resignation toward or even a preference for authoritarian rule. An intervening variable - quite literally - is the U.S. presence and influence over drug policies and the institutions charged with their implementation, which takes away from the GODR as the proper authority, by just war theory, in declaring or engaging in the war on drugs. The increases in crime and continuing drug traffic provide a just cause for continued drug control efforts of some kind, though whether the money one country can put toward these efforts is in proportion to the size of the problem is questionable and further raises doubts about the probability of success in the war on drugs. Last, drug control is necessary considering the levels of violence and crime, but structural efforts to improve economic opportunities and quality of life for Dominican citizens may be equally necessary. What 
is not clear is whether stronger policies that come at a cost to already weak or vulnerable institutions are an absolute necessity.

The newness of democracy in the country makes conditions within the Dominican Republic somewhat favorable for its preservation in spite of the surge in crime and violence. The lack of specific expectations perhaps means a lower likelihood of destabilization. But again, apathy, a scarcity of concern for and awareness of citizen rights, and the number of people without a definition for democracy may allow corruption to continue at the top level or where power is concentrated within the system. Efforts to strengthen the existing structure may be good for reducing traffic to the U.S. but not necessarily for the health of the system overall in the Dominican Republic. This kind of harm to democracy should not be considered justice in the war on drugs. 


\section{The Dominican Case on the Ground}

The co-operative efforts of the USG and GODR only address part of the drug traffic problem, and do so primarily at the international level. As drugs transiting the Dominican Republic have increased, so has awareness of the limited capacity of domestic institutions to confront them. The late development of drug enforcement policies in the country suggests the lack of a domestic drug consumption problem and market until recently. Some have argued that drug consumption has been seen as a foreign issue by Dominicans, primarily a U.S or European problem. Increasing demand elsewhere has created more traffic through the Caribbean, which then gave rise to domestic consumption and increased violence caused by addicts and dealers alike. Efforts to control this new local demand have only come about in recent years but have also uncovered the need to address the deficiencies of the institutions charged with preventing, controlling, and prosecuting crimes and the fact that they themselves are not immune from the influence of drugs. The central pillar of these efforts is the Plan de Seguridad Democrática and its police reform program Barrio Seguro. This chapter looks at recent research intended to evaluate and assess the results of these programs thus far on levels of drug crime and citizen security. By doing so we may again see how the war on drugs is affecting democracy, and whether the effects fulfill the requirements of a just war.

\section{--About the Plan de Seguridad Democrática and Barrio Seguro--}

The Plan de Seguridad Democrática (PSD) was written in 2004. By that year, insecurity had become one of the most pressing concerns for citizens of the Dominican 
Republic (Newlink, June 2008). The PN had become deprestigiada - the police had little credibility, a very poor reputation, and the public had little confidence in the institution. At the same time, the prison system was on the verge of collapse, and jails had essentially been converted into universities of crime (ibid.). This situation in many ways was the result of extreme poverty in some sectors, as well as other social, cultural, and political factors, as previously discussed.

The solution to these problems was the PSD, with the central working concept of addressing the multiple causes of crime by bringing the presence of the state back to all parts of the national territory. The two fundamental principles within the PSD are to reestablish state authority through police reform, and to guarantee the basic rights of all citizens. PSD programs were first begun in February of 2005 and represented the first integrated effort to design and implement a policy of citizen security in the Dominican Republic (Newlink, June 2008). The pilot program of Barrio Seguro (Safe Neighborhood) began in August 2005 in the Capotillo section of Santo Domingo. This program was then extended to other areas in the capital as well as to the northern city of Santiago. The basic principle behind the program is to recuperate the public space through the coordinated efforts of various state institutions while creating an increased police presence in the neighborhoods.

As laid out in a government evaluation of the PSD (2006), the premise of the plan is to make fighting violence and crime a priority of the state, as growth, equity, and equality of opportunity are not possible without democratic security. The PSD recognizes that violence and crime have multiple causes that must be addressed in an integral manner. The participation of the community, the institutions of the state, and 
civil society constitute a central axis of the plan. The multi-pronged approach means attention has been given to improving education and health, the creation of local public offices and victim centers, as well as sports and cultural programs.

The PSD contains provisions for improving the criminal police within the country. Efforts toward institutional strengthening include the creation of a communitarian police force trained by the PN and the armed forces (PGR, 2005). This training was to include a strategy of communication in an effort to improve the negative perceptions the general public has of the police overall. The plan's dual goal is to confront crime while preserving democracy.

One problem in creating such a plan was a lack of accurate information about the extent of crime in the country (PGR, 2005). The complexity of crime in the Dominican Republic, as anywhere, lies in the multiplicity of areas in which crimes occur and the number of actors involved. The PSD speaks about the importance of community involvement in fighting crime, as well as the decentralization of efforts. Both of these can be a challenge, especially where the community itself is run by criminal organizations or people have little sense of civic engagement or duty.

Upon his election to a second term in 2004, President Fernández came back into office in the middle of a period of very high citizen insecurity. Daily accounts in the press documented the level of crime in the country. The number of homicides more than doubled between 1996 and 2005, rising from 1,032 to 2,236, with the largest escalations beginning in 2002 (Informe, June 2007). Worse was the impunity the perpetrators of these crimes appeared to have, and the lack of a coherent and viable plan for the police and judicial authorities to confront crime. 
After 6 p.m. most people just wanted to go home; home had become a refuge and the level of crime made the population antisocial. This tendency to return home and stay there meant little sense of community and low levels of civil society development. During this same time period, citizens had lost the ability to enjoy public spaces; the parks were dangerous and every street corner was a drug post. Gangs were more likely to be in charge of the neighborhoods than were the police. The woman I stayed with during my trip to Santo Domingo in June of 2007 told me the same. Members of the household rarely went out after sundown. According to the police report, all of this affected the normal operation of society by altering recreation and social activities as well as commercial operations.

The PSD was put forth as the remedy and recognition that Dominican society could not continue in this manner. The plan was to make a diagnosis of the underlying problems, formulate a strategy, and execute a plan to carry out the strategy, with the ultimate goal of returning peace and tranquility to the Dominican family. The first step was to identify the areas within Santo Domingo and Santiago most affected by crime. These were Capotillo, Gualey, 24 de Abril, y Villas Agricolas in Santo Domingo; and La Joya, La Otra Banda, La Yaquita del Pastor, and Cienfuegos in Santiago. Most of these same neighborhoods appear in the studies done by Newlink discussed below.

The diagnostic process found that people thought the police were corrupt and citizens would rather take matters into their own hands. At the same time, police felt the people were colluding with the criminals. Fear was high - no one dared challenge the criminal organizations which had taken over community space. Neighborhoods had become battlegrounds and innocents caught in the middle had been injured or killed. 
Police capacity to deal with the problem was low because of few resources and high corruption, as well as inconsistent police work, erratic and coercive practices, or a complete lack of action at all.

The plan formulated between August 2004 and August 2005 became known as Barrio Seguro, which was then put into practice beginning in August 2005 under the direction of Major General Bernardo Santana Paez. The plan was guided by the idea that the most important charge of the government is to fight crime without compromising human rights: "El más grande de los retos de este gobierno fue enfrentar la delinquencia, sin que se produjera una degradación del disfrute de los derechos humanos" (Informe, June 2007: 4). The following sections will explore how well the government and these programs have been able to live up to that standard.

\section{Internal Evaluations of the PSD}

The police's own evaluation of their efforts can be divined from some internal reports on the implementation of the Barrio Seguro program. In one such evaluation, the Barrio Seguro program is called the most important reform process for the police institution in 70 years (Informe, June 2007). The report claims that never before had the police been credited with such levels of respect, support, and consideration by the citizens. The plan has created a new alliance between the police and the community, and for the first time, neighborhood and community leadership joined forces with the police to confront criminal activity. The public perception of the police changed; they were no longer seen as the old repressive force but a model institution of public order. These assertions sound good but there is little hard data presented in the report from which this 
conclusion was drawn. The only explanation offered for how such a change of opinion could come about so quickly is simply the success of the Barrio Seguro program.

Barrio Seguro contains six main areas of action, each with short, medium, and long range goals. These areas are: to create an efficient preventive police force, to deepen academic reforms for police training, to develop and implement a modern system of criminal investigation, to bring the PN closer to civil society through community police, to design and organize management of the police force so that each area is administered and equipped to fulfill its functions, and to develop an effective internal affairs division.

In the first area of action, the number of patrol officers was increased from about 800-1000 to approximately 9000-11,000 backed by the military (Informe, June 2007). Where all these new officers came from is not specified, nor is there any mention of what training they received. According to the report, this increase in officers resulted in a decrease in crime. Barrio Seguro has allowed the police to achieve in a few months what they were not able to do in the previous 70 years. The report again claims that there has been a positive change in police action throughout the neighborhoods, which corresponds to an improved image of the police in the public's perception. Again, there is no specific data presented to corroborate this assessment.

In the second area, "it is not possible to bring about real change in the police institution without a profound change in the mentality of its members" (Informe, June 2007: 13). In order to bring about real change in the police institution, it is necessary to change its members' ideas about their mission and function as officers of the law. This change was to come about through new information, technology, and education for police 
personnel. The report provides a long list of training opportunities offered by the PN and other institutions outside the country, including with the Miami, New York, and Colombian police forces. Some of these opportunities were made available to both police personnel and community leaders. What is not clear is whether these trainings were mandatory or if the participants who attended trainings were high level officers, the rank and file, or both. Considering the idea that institutional culture is strong and difficult to change, it might be prudent to know which members attended. Clearly, new recruits can be trained in the new attitude and yet have to confront the old ways in their daily work.

To address the third area, in addition to training, police need the right equipment and techniques or technical supplies in order to apply their new knowledge on the job. Development and implementation of a modern criminal investigation system is part of that. The report indicates that the Dominican police need a system that is "adequate for the realities of Dominican democracy" (Informe, June 2007: 41). This is recognition that democratic practices are developing and all institutions need to progress in that same direction.

The new system of justice requires new kinds of evidence, procedures, protocol, and of course more training and equipment. In March 2006 the United States donated eight kits for the recovery of fingerprints. In mid-2007, the police were about to open several new offices and labs. The system also needed a well-formed police force and an "investigator with a very different profile from the one we have traditionally known" (Informe, June 2007: 41). This is an apt observation again considering the entrenchment of the old ways of doing things through patronage and favors. At the same time, 
according to the numbers in the report, the new procedures have also resulted in more cases solved.

In the area of intelligence, the report notes an increased capacity for electronic "servicios de vigilancia" (surveillance), but "always within the letter of the law and respect for the rights of citizens" (Informe, June 2007: 46). In other words, the police have found better ways to obtain information and keep track of suspected criminal activities but without any arbitrary spying on the citizens. This appears to be in keeping with the spirit and letter of individual rights as written in the Dominican constitution and discussed in the preceding chapter.

In addressing the fourth area, the report says Barrio Seguro is an opportunity to bring the police closer to the community. The negative history of the institution is still alive in the minds of the people, and is a major reason for creating a community-centered police force. The report sites numbers showing decreases in crime, deaths in particular, in all neighborhoods except La Cienaga (though the numbers there do not show any increase either) as a result of community police. The future of the plan was to extend it to another 21 neighborhoods, some if which has already been done at the time of writing.

Working toward the goal of organized and efficient management of police administration involves making sure each area has what is needed to fulfill its duties, but most important is regulating the contracting of goods and services within the institution to ensure fairness and oversight. The report indicates that the police were working to create an ethics committee to help promote the prevention of corruption. The administration had already reached an agreement with a major bank, Banco de Reservas, to pay police employees directly and electronically. This was meant to eliminate the 
practice of intermediaries whereby disbursement was controlled by employees' superiors or other private companies and could be used as leverage. The implementation of something as simple as payroll direct deposit was hoped to reduce a significant amount of intra-institutional corruption and influence over subordinates, thereby eliminating personal patronage and enhancing professionalism and fulfillment of the institution's new mission.

Finally, to address the sixth area of focus, the police acquired a new location with 14 offices for the administration of Internal Affairs (IA). Complaints or accusations could then be made away from central police locations and are therefore more discreet and secure. The department was increased to 159 members, and during the first three months of operation at its new location (through April 2006), IA conducted 1,863 drug tests on members of the police force, of which $98 \%$ came back negative (Informe, June 2007). Of the 30 cases that were positive, 25 were for cocaine and two were for cocaine and marijuana. All of these officers were relieved of their posts. By September of 2006, a total of 3,884 drug tests had been administered, of which 88 or $2.2 \%$ were positive (ibid.). The report indicates that all of these cases came from within the lower ranks of the institution. What it does not indicate is whether upper-level employees were also tested.

At the time of the report, internal affairs had created a plan of action against corruption which was to be implemented during 2007 and included lectures and talks, 6,000 drug tests, depurar or the purging of as many as 6,000 officers ${ }^{4}$, formal publication

\footnotetext{
${ }^{4}$ For example, DR1 Daily News reported on June 22, 2007 that a major, a captain and two low level officers in the National Police were dishonorably discharged from their duties for being part of a contraband ring and sent to justice. Police Chief Bernardo Santana Paez said that there is no place for
} 
of the rules of the institution, and the adjustment of salaries based on function and quality of performance, among others. It is striking and somewhat shocking to think that the formal publication of the rules is something that was new and still in need of implementation at that stage, and yet it is also not surprising when one considers the history and nature of the institution and its role as an extension of the executive for so many years.

As part of the evaluation of the results of these efforts, the PSD is hailed as the most profound process of transformation the police institution has "suffered" through since its formation in 1936 (Informe, June 2007: 63). The report asserts that the plan has proven to be functional and is "the most suitable instrument for modernizing the institution and for fighting crime in the country through scientific methods" (ibid.). Even so, the report recognizes the need to develop an aggressive campaign to reach the citizens and to continue improving the police image, their salaries, and quality of life. There is still work to be done to fulfill the need to change the vision, mission, and values of the institution overall.

A number of questions are raised by the information contained in this report. The brief time period covered by the data presented leads one to ask whether the reductions in crime are a direct result of the Barrio Seguro program or can even be considered an indication of any trend at all. Other factors that may have influenced rates of crime for the time period are not addressed. The report also offers no specific explanation for why

corrupt cops in the Dominican police force. The chief said that proof of the efforts to purge the police is that in the past these events would have been kept private and would not have made headline news. On July 25, 2008 DR1 Daily News reported that in the previous 23 months the DNCD had fired more than 5,000 agents found to be involved with drugs, and on August 29, 2008 reported that 947 police officers had been removed from their duties over the past year. 
there was an increase in homicides in the years immediately before the program began nor does it address whether or not any of them are directly attributable to police action or misconduct. Last, there is no mention whatsoever of bribes within the section discussing internal affairs. Drug use and domestic violence by police personnel are certainly important issues but they are not the only possible areas for investigation. One wonders again if upper-level officers are as highly scrutinized as the individuals at lower levels.

For further insight into the police, I attended a meeting of the chiefs of the National Police in Juan Dolio, Dominican Republic on June 26, 2007. They had gathered for a day-long conference to discuss and strategically evaluate various initiatives within the institution as a part of the PSD. At the time, General Bernardo Santana Paez was the head of the organization and he gave the opening presentation. He began by saying that authorities had not been able to count on a coherent contingency plan. From 1996 through 2007 the number of homicides in the capital steadily increased, though he noted that the number of homicides dropped from 2005 to 2006 specifically. ${ }^{5}$ During the previous ten years the city experienced a loss of communal space, especially after 6 p.m., and there had been a change in commerce, nighttime activity, and recreation.

Paez called for the reestablishment of the authority of the state in order to guarantee basic citizen rights for all, and this meant developing an effective preventive police force. He did not say how this would be possible, but noted that the recent

\footnotetext{
${ }^{5}$ Coronel Brown Perez presented at a later conference data from January 2005 to August 2007 that was collected in one section of the capital city. The area is in the northeast section, bounded by the Rio Isabela, Rio Ozama, and the Avenues Gomez, 27 de Febrero, Kennedy, and San Martin. This area is known for being poor and prone to crimes, and is divided into 14 supervisarias, 11 of which were within the Barrio Seguro program. He found that the number of violent deaths dropped 20\% from 2005 to 2006 and $24 \%$ from 2005 to 2007 (59 to 47 to 45 ).
} 
decrease in the homicide rate was evidence of some success already within the program. He also noted a certain typology of homicides in the city, in particular "muertes en acciones legales" or people killed by police officers in the course of carrying out their duties. Citing a report published in collaboration with the World Bank and Amnesty International, and the U.S. State Department Report on Human Rights in the Dominican Republic March 2007, Paez claimed that the number of people killed by the police had dropped, while transparency within the police institution increased and internal affairs had improved. Historically, there have been times when the number of people killed by the police was huge; therefore, it is significant to have the number drop, especially as a result of legal police action. The question is whether or not the increase and decrease in deaths was a direct result of police work or something else. Paez concluded that the program has been a success and will continue to be, and he found much reason for optimism.

At the same conference, General Daisy Liriano - the only female chief in the organization - spoke about her work in IA. She reminded the audience that there is a question of institutional capacity to be addressed, especially for continued success in the future, including the organization's ability to track people and follow leads. The police needed access to technology such as fingerprinting or listening devices that were not being used or were not allowed by law. A number of these are things discussed within the INCSR as having been planned or implemented, though perhaps not on the domestic level or independently of U.S. operations. Efforts made within the DNCD, for example, may not have an immediate effect on police work, and it is interesting to note that there is no separate drug unit within the PN's structure. 
I sat with General Santana Paez during lunch at the conference and he offered additional comments on the $\mathrm{PN}$ as an institution. The PN does not have the manpower to control drugs in the country, especially in the rural areas. There are not enough police officers, and so the danger of the police being outnumbered by members of the local drug syndicates is ever-present. Their corrupting power over both the civilian population and the police and government institutions is also a constant threat.

The police and the military each have a different raison d'etre, and separate spheres of power and responsibility. This is true in theory if not always in practice, especially in the Dominican Republic where the police have been more of a military-like body under the control of the president or others. They have been historically more apt to imprison and destroy than to serve and protect. An illustrative comment Paez made was that he believes the term 'chief' of police is less intimidating in its English translation than is the term 'jefe' in Dominican perception. In the historical context of civil-military relations in the country, a police boss is indeed a more powerful and intimidating figure than a local police chief in the U.S. context. Others at the table mentioned the efforts being made to improve and create a professional police force, including training and cultivating the next generation of police officers as civil servants rather than as part of a political or militaristic body. Some felt this kind of transformation was the key to improving relations with the public and perceptions of the institution.

It was exciting and interesting to sit and listen to the conversation amongst the top police official and his consultants, all the while surrounded by men in earpieces. It was also informative to attend the conference and see the top officers looking bored, answering their phones, and talking or surfing the internet during the others' 
presentations. What might have appeared as a lack of discipline or professionalism can also be seen as a reminder of the humanity of these officers. Indeed, there was overall a sense of great ideas and vision for the police as an institution with much potential.

Additional presentations during the afternoon session discussed the importance of perceptions of law enforcement institutions among the population. The supposedly improved public opinion of the jefe has not yet translated into an improved opinion of the institution as a whole. By the police's own statistics, crime rates may have gone down in the country, but the perception among the people that crime is rampant and not welladdressed by the police continues. It is difficult to find concrete solutions to the various problems with reform and reform plans, and the ways those plans are received both internally and externally. There is also the question of the role of the press in creating perceptions of crime and police: How can all the entities that help form public opinion nationally and internationally be influenced and communicated with effectively? The problem the police have is making sure their work is accurately represented. Public opinion, and that of external governments, affects how programs are funded and how they function in practice.

In a 2007 report by Major General Vinicio A. Hernández of the Internal Affairs division, several of the department's goals and activities were evaluated. The goals were to establish methods of preventing police misconduct, to help the population learn about the function and services performed by IA, to make quick and effective response to investigations, to make intelligence work more efficient, to broaden the coverage of services, to improve capacity among IA members, to reorganize internally, to increase motivation among IA members, to improve administrative and budgetary control, and to 
make operations more efficient. All of this was to be done by IA and the PN, along with other national and international organizations and civil and community organizations. Internally, the plan was to provide training for personnel in domestic and international programs. Externally, information would be provided to the community through newsletters, meetings, and talks with the $\mathrm{PN}$ at various places such as training centers and through central and regional units.

In $2006,14,292$ people were the beneficiaries or participants in these programs. At the time of reporting in the fall of 2007, another 12,976 people had participated. The number of internal investigations dropped from 773 in 2006 to 364 in the first eight months of 2007. Intelligence indicated that in 2006, nine percent or 35 of these cases were of police involved with drugs. In 2007 the number of cases was 13, or $11 \%$. The police implemented drug testing of its personnel during this period. In 2006, only two percent of the 4,168 officers tested were positive. In 2007, of 3,259 individuals tested, only one percent came back positive.

In 2006, 166 officers attended training courses, and another 345 attended in 2007. The report offered several pictures of public meetings and talks with police, as well as of newly purchased equipment, but no other data about them. The positive aspect of the programs came from the lessons learned: Education and information is important for members of the police in order to prevent misconduct, continuity of planned actions is necessary to keep services operating well, and more personnel need to be integrated into the planning and execution of activities. The obstacles, of course, are resources and money to keep programs going and the need for better technology to carry out the process of investigation and intelligence. 
The community has helped by inviting officers to speak and by reporting cases of misconduct. The report also notes that the police are gaining the support of the public as evidenced by the number of cases brought to their attention and the closer relationships the police have with civil society institutions. Not surprisingly, the report's final conclusion is that the program needs to be maintained and given all the money and resources that have been requested.

According to an internal government evaluation of the PSD (2006), the results of Barrio Seguro have been optimal and progressive, but some state and civil institutions have proven to be deficient at carrying out their own plans of action to confront the multiple causes of violence and crime. While some results have been achieved, the conditions have not necessarily changed. A lack of ability or capacity within the PN makes expansion of the program to other areas difficult. The PN has worked with police academies in New York City and in Colombia, as well as with programs at John Jay College in New York and officials from the Miami police department to train program leaders. An additional 106 participants were set to begin their training in July immediately after this report was released.

Efforts to address structural issues are less well-covered by the various official reports under consideration here. There is some mention of school programs in the form of science and technology scholarships and reading programs, as well as health programs overseen by the first lady and food rationing programs as a part of the general PSD. Twelve homes, one in each of the neighborhoods where Barrio Seguro operated, were built for the poorest families as selected by community organizers. Sports activities organized, efforts to reduce power outages, distribution of clothing and medicines, and of 
the computers to be installed in some community centers are also mentioned briefly. While all are important aspects of the PSD and speak to its "multi-causal" approach, the information given is vague, with few numbers or specifics about where and how they are being implemented or will be sustained. Last, the report shows a list of 21 different organizations and institutions that are involved with the PSD, but there is little other specific information about their involvement. This last point reflects the major criticism voiced by several evaluations of the program (discussed further below) about the lack of follow-through by many of the institutions involved with PSD and the lack of interest in the plan's goals among the individuals working within these institutions.

\section{Press Evaluations of the Drug Predicament}

During the last week of June, 2007, the Dominican newspaper Diario Libre published an editorial stating "Este país se jodio"" (this country is screwed) because democracy is not truly representative and money is not spent where it should be. The writer's sentiment is similar to the general pessimism about the state of affairs in the government that I noticed among many of the Dominican people I have met. It made me wonder if there could be much hope of creating any optimism among the citizenry and the kind of community involvement in police, government, and civil affairs that the PSD envisions.

An article published on June 30, 2007 discussed the new police graduates becoming community patrol officers. More than 500 new patrol officers joined over 2000 already in Santo Domingo. Paez called upon them to respect human life and rights, saying that this is a new era - old practices had reduced citizen confidence and now was a 
chance to move forward. The new program sought education and professionalization of the police, especially for the young student recruits. In contrast to the optimism of these words, the paper also noted that the salary for patrol officers is $\$ 3000 \mathrm{RD}$ per month, plus food and health care for family members. The reality is that this is a small amount to live on, roughly $\$ 85$ U.S. and hardly enough to pay for a home.

The July 4, 2007 edition of Diario Libre contained coverage of the major protests west of the city of Santo Domingo that shut down the main roadway. People in the protests had been living without running water since my arrival in the country ten days earlier. General Paez was quoted in that day's paper saying that the National Police were there to preserve order. Their job was to protect the citizens in these situations, not to kill anyone. I find it interesting and informative that this was something that needed to be pointed out. An article like this one highlights both the problems of infrastructure and basic services in the Dominican Republic as well as the recognition that the repressive tendencies of the police continue. Articles like this illustrate the context in which drugs and drug money can easily penetrate society through both corrupt institutions and needy individuals.

Another paper in Santo Domingo, Clavo, is a free weekly featuring mostly opinion pieces. One article published on July 5, 2007 addressed another topic that had been in the papers that same week: the GODR's proposed purchase of eight airplanes called tucanos from Brazil for the purpose of anti-drug air patrols. The author felt that the money spent on these planes was a waste and would be better spent on water, education, and other pressing needs for the people of the country. A familiar complaint in many countries, including the United States, where more money is spent on defense 
measures than on social programs, it also shows how everything eventually comes back to drugs: the logic behind such a major purchase, the training of new police recruits, and the reorganization of neighborhood patrols is to fight drugs.

The tucanos airplanes have been a frequent topic in Dominican newspapers. A number of people have felt a certain amount of incredulity about how the administration has the money to buy them, or why the money was not going to be spent elsewhere on other basic services the population needs. ${ }^{6}$ I would argue that this purchase is led by international cues and fits with the models and methods being used elsewhere in the international drug war. This purchase looks like fulfillment of international obligations to stop north-bound drug traffic from South America. It is likely to impress authorities in the United States and elsewhere abroad and appears a more direct approach to drug traffic than efforts to change the underlying structural problems within the Dominican Republic - even if those same structural issues contribute to the problem in the first place.

In the November 18, 2008 edition of Listin Diario, Senator Wilton Guerrero criticized the proposed purchase of the tucanos. By this time both the Senate and the Chamber of Deputies had approved a \$93.6 million loan from the U.S (see DR1 Daily News September 17, 2008; DR1 Daily News November 12, 2008). Guerrero argued that the planes are just as likely to be used to bring more drugs into the country as they are to stop them. He claimed that military boats are already involved in the drug trade and that

\footnotetext{
${ }^{6}$ As reported in DR1 Daily News June 19, 2007 President Leonel Fernandez announced the purchase of nine Super Tucano airplanes from Brazil. The US $\$ 45$ million deal was to be financed by the Brazilian National Economic Development Bank (BNDES). The planes are intended for use in the fight against drug trafficking operations using the Dominican Republic as a transshipment point to the United States. The airplanes would be paid from a new 12-year scheme funded by US\$1 levied on tourists visiting the Dominican Republic. DR1 noted in the November 16, 2007 edition that controversy continued to surround the purchase of these planes as many feel they are too expensive, out of date, and unsuited for combating the drug trade.
} 
there is a lack of oversight and a clear idea of who is responsible at the top, which makes it possible for any corrupt senior official to appropriate government equipment for illicit use. The debate over the funding for these planes was taking place against the backdrop of the recent and not insignificant corruption scandal in the Peravia province. In August 2008, seven suspected drug dealers were killed in Paya, just outside of Baní, a town about 65 kilometers from Santo Domingo (Listin Diario, August 5, 2008).

After news of the massacre broke it was not long before the complicity of the authorities in the case was called into question (DR1 Daily News, August 7, 2008). Senator Guerrero noted that for years in Peravia the PN, DNCD, and state prosecutors had aided in the growth of the drug trade and had profited from it. Eye-witness accounts claimed drug enforcement authorities were involved in the murders. While no arrests were made immediately, all officials in the Paya Police Department were replaced (Hoy, August 8,2008$)$. The DNCD fired back at Guerrero claiming his accusations were irresponsible; meanwhile, President Fernández established a commission to investigate the allegations (Listin Diario, August 8, 2008).

One month later, Senator Guerrero was in the news again criticizing the commission's work and calling it a comedy (El Diario Nuevo, September 3, 2008). By mid-September, the PN announced that 13 men would be charged. Unfortunately, this announcement did not boost confidence in the police work being done to bring those responsible to justice, or to pursue official complicity in the case:

In an editorial in Diario Libre, Homero Figueroa says that the police report and accusations are surprising, not for the 13 names that are on the list of accused, but for the ones that are omitted. 'The report on the Paya case provides details about the men who carried out the murders, but it says nothing about the mastermind moving the pieces,' he writes. 'The body of the criminal is 
headless,' he comments. 'The Dominican public was expecting a report that would disclose the denounced complicity entanglements. The country will be shocked, the Police had said. The shock did occur, without doubt, but because of what was not said, more than for what was said. The capture of the workers, leaving the boss free, only paralyzes the criminal factory momentarily. But the abundant criminal labor force will put it back into production,' he concludes (DR1 Daily News, September 18, 2008).

The newspaper Hoy echoed this sentiment a few days later:

Many Dominicans continue to find it strange that the investigators, especially from the National Drug Control Department, have not been able to locate the drugs and money that was up for grabs on the night of the massacre of seven suspected drug dealers in Paya, Baní. As has been said, it is known who was there, who was waiting for the shipment that came by sea, who participated in the murder, the vehicles that were used, etc. Then how is it possible that the authorities remain silent about the whereabouts of the drug shipment or the money? Or could it be that they do not want to reveal what was found out in the investigation to the general public? (September 22, 2008).

Throughout October and the following months, Senator Guerrero continued to argue that the Presidential commission on the crime had not gotten to the bottom of the case, though the police did name a Navy officer as the operational chief behind the murders (Listin Diario, October 15 and 20, 2008). Senator Guerrero continued to question why the authorities still had yet to disclose what had happened to either the drugs or the money that was recovered the day the investigation began (Listin Diario, November 18, 2008). In the same day's paper, another official commented that the Baní incident has had a positive effect as well. It has drawn attention, especially from the United States, to the true depth and severity of the problem - both of drug traffic and official complicity in it within the Dominican Republic. It was not until the next day that the President made an official statement about the incident:

Issuing his first comments in response to the massacre of seven suspected drug traffickers in Paya, Baní in August, and other cases involving Navy officers and their affiliation to international drug rings, President Leonel Fernández 
described the scandal as shameful, as reported in Hoy. Critics had found it odd that the President has failed to issue any public statements about the cases of corruption and drug involvement by top-ranking military officials that threatens the DR's national security and stability. Nonetheless, Fernández said that he was sure that the Navy was still in a position to redeem its image (DR1 Daily News, November 19, 2008).

The ongoing dialogue in the press reveals public frustrations with the government and police reforms, as well as the difficulty of finding solutions to both drug crime and official corruption. It is clear from these accounts that the positive achievements the police have found for themselves in Santo Domingo have not yet extended elsewhere in the country. At the same time, the ability of the press and the public to express opposing points of view on these and other topics is one important piece of a free democratic society though this freedom may only be enjoyed by certain sectors of the society. As we shall see later, resistance that is easily expressed by elected officials or academics and written about in the papers is not necessarily mirrored by all people in all neighborhoods.

\section{Independent Evaluations of the PSD}

In this section, I look at surveys conducted with police personnel and the general population in the Dominican Republic and published between 2006 and 2008 that evaluate the state of citizen security and the effects of government reform programs. While this represents only a brief period of time, the surveys provide a picture of the levels of citizen confidence in government institutions and some preliminary results of the new programs, as well as their potential for the future. The data are comparable across time and offer contrasting points of view when assessed alongside the official reports discussed earlier. 
A number of private or independent organizations have conducted studies evaluating the effect of the PSD and Barrio Seguro on citizen perceptions of security. The studies show that some effort has been made to reduce criminal activities, improve police work, and create positive relationships between the police and the public. At the same time, the interpretation of the data can be subjective, reflecting both pessimism and optimism about the achievements of the programs and their future potential (interview with Bielka Polanco, 2008).

\section{-- Police --}

In a study carried out by Newlink Political published in 2007, 1031 police personnel from all over the Dominican Republic were interviewed during October 2006 about communications within the institution. Fifty-four percent of police personnel said they do not receive any information or internal communications. Of those who do, only $38 \%$ said they received this information on a daily basis. When asked about the kinds of information received, the most popular answers were information about work and obligations, orders or instructions, general information about the institution, and standards or lessons for improving work. Among the least popular answers was information about how to treat citizens and police discipline.

Internal communications are most frequently made in person or by phone. Fewer respondents mentioned written methods such as memos, bulletins, email, or written orders. The majority, $69 \%$ of those surveyed, said they stay informed through their direct supervisors and feel satisfied with that arrangement. These numbers show little variation across regions one through four (Distrito Nacional, Santo Domingo, Northwest, and 
Northeast), with length of service, or rank, although in the South only $52 \%$ said they are satisfied, while in the East $100 \%$ said they are satisfied. It is possible that in spite of the anonymity of the study, police officers interviewed in the eastern region, which includes known drug-trafficking towns like San Pedro de Macoris, were less likely to speak against the institution.

When asked how much they know about the police as an institution, 38\% said they know it well (49\% of those on the force 10 years or longer), $39 \%$ said they have a general idea (50\% of those with the highest rank chose this option), and $22 \%$ said they know very little, with $50 \%$ of those with less than one year on the force choosing this option. Only one percent of all respondents said they knew nothing at all. Some lack of awareness on the part of police officers about the institution's history could be considered problematic as that may mean less appreciation for the current goals associated with reforming the institution. Interestingly enough, when asked what kinds of information they would like to receive, the most popular answers given were information about police reform (27\%) and opportunities for promotion (17\%).

In another study conducted by Newlink Political also published in 2007, police personnel were interviewed about their work practices. For location of work, or where they do the bulk of their service on the force, $39 \%$ said in the police stations, the most popular answer. Only one percent each said investigations or communications. The highest ranking officers do not work as police escorts or in foot patrols.

The most surprising part of the survey were the answers given for work schedules. The majority of police personnel, $58 \%$, work during the morning shift, while only $24 \%$ worked rotating shifts, and a mere five percent worked at night. This is striking when 
compared to data that shows the bulk of crime taking place at night. In addition, only four percent of those surveyed claimed to be employed on a full-time basis. One wonders about the efficacy of any efforts to increase salaries and improve the image of a professional police force when the vast majority of them are employed part-time. Of those surveyed, $81 \%$ intend to stay in the police force for as long as they are able to. Most feel there are good opportunities for a career in the police and that it will provide them with a wide variety of tangible benefits including pensions, life insurance, healthcare, stable work and income, homes, cars, and so on. Seventy-five percent said they are very motivated by their work, but $72 \%$ do not feel they are paid well for their rank. Sixty-six percent see their work in the police as a profession, $23 \%$ see it as a mission, and only about $11 \%$ see it as just another job. This shows an attitude of professionalism in spite of the part-time status and low pay for the majority of officers. Although few are employed full-time, $89 \%$ of the officers surveyed said they do not have another job. This may be a reason that police officers are vulnerable to corruption, as a means to supplement meager salaries and because they have extra time on their hands in which to engage in illicit activities.

Police were asked about their feelings of security in different situations they encounter on the job. When helping victims, $72 \%$ say they feel secure and an additional $15 \%$ said very secure. The number drops slightly to $69 \%$ when officers are called to respond to questions in the street, and more significantly to $44 \%$ when they must knock on the door of a private residence. In the latter instance, 37\% said they feel insecure, 
indicating that police personnel are aware of their own vulnerability in certain situations, and that some mistrust of the population continues to exist. ${ }^{7}$

Most police, $64 \%$, are not assigned to a particular barrio or sector. Of those who are, $69 \%$ say they know the inhabitants of that area and $57 \%$ know the community leaders. This is in contrast to the surveys discussed below that show the opposite from the neighborhood populations themselves. Most citizens do not claim to know the police even though the numbers here indicate the police know the citizens to some degree.

When asked which infractions they encounter most often during the course of their work, the most popular answer at $33 \%$ of those surveyed was none at all. Street fights $(21 \%)$ and assaults or robberies $(13 \%)$ were the next most popular answers. Drugs was cited by only $4 \%$ of the respondents. When asked if they have ever had to draw their weapons, $55 \%$ said never and $25 \%$ said almost never. There are a variety of reasons or situations given in which an officer might be motivated to use his or her weapon. The most popular answers given are during muggings or robberies (14\%), hold-ups by individuals (13\%), and perceived intent of aggression toward the officer (10\%). Confrontation with an armed criminal was cited by only one percent of respondents, even though this scenario might be considered the general rule in police work of when it is acceptable for an officer to use his or her weapon. When asked how many times they had drawn their weapons during their careers, $45 \%$ said one to three times, $14 \%$ said four to seven times, and $7 \%$ said eight to eleven times. What is striking is that $32 \%$ said they

\footnotetext{
${ }^{7}$ A report in September 2007 noted conspiracies by drug trafficking networks to murder enforcement officials. A December article said that fifteen drug control agents and police officers had been murdered during the previous three months. The National Drug Control Department (DNCD) reported 237 attacks against their agents and that they had lost three while on duty. In September and October, 12 police officers died in confrontations with criminals. From January to August, 48 policemen died on the job (Hoy, September 14, 2007; Listin Diario, December 6, 2007).
} 
had drawn their weapons more than 12 times, and $87.5 \%$ of those serving for less than a year had already drawn theirs at least once. In addition, $81 \%$ said they had never been investigated for doing so. There may be an overall feeling of insecurity among officers that justifies the drawing of their weapons, or a generally lax attitude about doing so. The survey does not show whether the respondents who were more prone to going for their weapons were primarily assigned to the higher crime neighborhoods or not. The lack of investigation of such incidents also shows a shortage of oversight within the police institution which may allow for increased police aggression toward alleged offenders and suspects. Particularly troubling is the high number of the least experienced officers employing their weapons. It appears the new training does not necessarily include specifics about using one's weapon as a last resort. These practices are not likely to inspire confidence or increase feelings of security among the citizens.

When asked to choose the characteristics most identified with the police and their activities, $36 \%$ and $32 \%$ say efficiency and intelligence, respectively. Another $18 \%$ said humanity while only $8 \%$ said integrity. When asked which basic principles guide police work, the most popular answer was protecting the community at 19\%. Preserving the public order and justice or fulfillment of the law came in lower with $8 \%$ and $4 \%$ respectively. The first question had a list of options to choose from while the latter was open ended and the answers more varied. The answers to the questions above show an internal perception of the institution that is at odds with the public's perception of it, the officers, and their mission.

The survey also included specific questions about the Plan de Seguridad Democrática and Barrio Seguro. Only $66 \%$ of respondents said they had heard of PSD 
but $95 \%$ were familiar with Barrio Seguro. The vast majority of police personnel agrees $(61 \%)$ or strongly agrees $(36 \%)$ that the program has improved relations between the police and the community. The numbers are similar (63\% agree and 33\% strongly agree) that the program has controlled crime in the areas where it has been implemented. When asked about the work being undertaken by the police to prevent crime, $49 \%$ said it was good and $45 \%$ said it was very good. As for the areas where the police need improvement, narcotics control was mentioned by only two percent of respondents.

In the final analysis by Newlink Group, the authors argue that there needs to be a better distribution of officers throughout shifts in a 24-hour period since only five percent of officers work at night, and because the majority of violent crimes occur between the hours of 6 p.m. and 6 a.m. If $33 \%$ of officers report that they do not encounter infractions of the law during their work, then it is likely they are not really working in police activities, especially considering the level of crime in the country, or they are not being put to work during the times of day when they are most needed. Since so many already work only part-time, this appears an inefficient use of what man-power is available.

The analysis also asserts that "the concept of a modern police force is one that is local or localized so that the officers know the community and are integrated into it. This ought to be considered a major flaw in the Dominican system" (Newlink, 2007: 61). There appears to be a good level of internal cohesion within the police institution, but it is troubling that so many officers claim they confront no crime at all, that many resort to weapons in any variety of circumstances (which may lead to high numbers of people injured or killed by police), and that few officers see drug control as an area in need of improvement. It is difficult to make change when few think it is necessary. As we shall 
see in the next section, a gap clearly exists between the perception the police have of themselves and the perception the public has of them.

\section{-- General Population --}

A study conducted by Newlink Political (December 2006), sought to identify baseline perceptions of security, crime, and the corresponding institutional responses among the inhabitants of eight neighborhoods in the Distrito Nacional and Santiago where the pilot program of Barrio Seguro had just been implemented. The researchers found a general sense of insecurity, and a feeling that crime had gotten worse in recent years. This group of respondents was most likely to name street crime, drugs, or lack of education among the youth as the main problem facing the community. Drugs were mentioned especially frequently in Santiago. When asked which problem must be resolved in order to increase security, the majority said street crime or the lack of neighborhood organizations, though drugs and lack of electricity also received high numbers in Santiago.

The majority of respondents - up to $83 \%$ - said the traffic and sale of drugs had increased in the recent past. As many as $87 \%$ said gang activity had also increased. Indeed, drugs, gangs, and official collusion were acknowledged as well-known by the community. For example, one of the respondents described how in his neighborhood of Capotillo, a known drug trafficker was the major benefactor of a sports team. He said it is a shame that the politicians spend lots of money on their campaigns and platforms which frequently are anti-drug and anti-crime - and but it is a known drug dealer who 
pays for the uniforms. Everyone is against drugs and gangs but looks the other way when there appears to be some benefit to the community.

When asked to qualify police work in controlling crime, $70 \%$ said it is bad, very bad, or just average. The perception of the police is that they are not well informed, trained, or equipped to deal with neighborhood crime. Most people think the police are closely associated with the criminals or the main gangs themselves. Victims of crime are afraid to make reports to the police for fear of infiltraciones. Some respondents recommended rotating officers frequently or replacing them with the military all together.

Upon visiting the police stations, the researchers found that the number of officials or officers there is between two and six, usually one detective and the rest uniformed. Detectives work long hours because there are not enough of them to rotate, especially in Santiago. Most criminal investigations rarely extend beyond the questioning of the regular informants, who are often part of the group being investigated. Other witnesses are few and participation by those in the community is not common practice, thereby limiting the information detectives are able to gather and use.

The study also found inadequate equipment for police officers, especially bulletproof vests for those confronting gangs and other armed suspects, and a lack of "locomotion" within the barrios, particularly the larger zones within Santiago such as Cienfuegos. Researchers found a lack of record keeping about which areas had the most incidents, and little or no follow-up in cases under investigation. The study found no clear objectives for officers and little supervision for patrols, all of which could limit the institution's ability to provide the kind of results that would inspire citizen confidence or effectively reduce crime and insecurity. 
When asked which feelings the police gave them, between 23 and $57 \%$ of those surveyed said fear. In only two of the eight barrios was fear not the most popular answer (security and a sense of protection were the other available options for this question). Many think the justice system favors those with money and connections, and the police are thought to be both incapable and unscrupulous. They were seen as far too willing to release or not process those detained. Trust in the police was low. As one respondent said: "It's that the police don't pay attention to us. We call them and they don't come. We go to the station and they say take care of it yourself as best you can." Another said: "When I need to recover something, I prefer to go to the perpetrators themselves before going to the police. They are a part of the problem." The majority, $68 \%$ to $82 \%$, said that police corruption had increased.

Rotating locations for police assignments was deemed preferable to permanent assignments by those surveyed in all eight areas, though the two options were more evenly matched in Santiago. When asked why, about half said rotation does not allow police to create relationships with the criminals and their organizations. When asked about the relationship between the police and the residents, in all cases the majority said either the police abuse their authority and lack respect, or they just barely fulfill their obligations. The former was especially prevalent in Santiago.

The study concluded that low social cohesion in the community inhibits socialization and the development of cooperative initiatives to confront crime. Most people react to violence and crime in an individual way, and find ways to ignore or tolerate it as a form of survival, particularly when the formal institution charged with confronting crime fails to deliver. This is another indicator of low levels of social and 
civic development among the Dominican population and a critical area for improvement and democratization. Police reform within the PSD is meant to counter these conditions, to improve police work and relations with the community in order to create space for peaceful civic engagement.

Another study intended to capture perceptions of the Barrio Seguro program was conducted by the Santo Domingo-based NGO Centro Juan Montalvo in 2006. This study drew a sample from four neighborhoods in Santo Domingo: Los Gandules, La Cienaga, 27 de Febrero, and Guachupita. This is a very small section of the city under study but one considered rather dangerous, especially the locations along the Rio Ozama. The sample included people ages 16 to 95 . When asked about Barrio Seguro, $65 \%$ of respondents said they knew the program and 29\% said they had heard something about it. Respondents were then asked what had been done in their neighborhoods because of the program, by indicating yes or no to each example. For military presence, $89 \%$ said yes. The vast majority $-73 \%$ or higher - said no to police stations, building schools, improving basic services, technological centers, and sports events. These responses are informative in light of the PSD's goal of addressing the multiple causes of violence and crime and its pledge to work with various organizations to create different kinds of programs and services. From these results it appears that the only visible change is an increased military presence. When asked if they felt the level of security had improved with the introduction of Barrio Seguro, $49 \%$ of those surveyed said yes a lot, and $42 \%$ said yes, some. When asked if they felt safe moving about the neighborhood, 52\% said they felt secure and $30 \%$ said very secure. Perceptions of security thus appear to be 
linked to increased militarization rather than other social and civil programs or opportunities for participation for the residents of these four neighborhoods.

Respondents were asked if they had visited a police station since the initiation of the program and $68 \%$ said no, they had not. Those surveyed were also asked to respond yes or no to possible answers for how the police treat the people. For cordial and friendly, $63 \%$ said yes, while aggressive and indifferent received only $7 \%$ each. This seems to be a different result than the Newlink study above that identified high levels of mistrust in the police, albeit in a different urban location. When asked how they felt about the treatment they received at the police stations, satisfied and very satisfied were each selected by $27 \%$ of respondents, but $39 \%$ said very unsatisfied, which is more congruent with the Newlink results.

Since the start of Barrio Seguro, $88 \%$ said they had not been the victim of a crime. Of those who had, the majority were victims of robberies in the street or at home. Twothirds said they did not know anyone who had been the victim of a crime. The survey showed some variation amongst the four barrios, but most of the respondents said that crime had diminished some or considerably. When asked how they now felt in their neighborhoods, $57 \%$ said secure and $26 \%$ said relatively secure, while five percent still said very insecure and one percent said they felt they were in danger. The most popular reasons given for these feelings of insecurity were drugs, few police, fights, poor lighting, known "crime zones", apathetic or complicit police, and gangs. About half of all those surveyed said they perceive more security since the start of Barrio Seguro, and about $29 \%$ said they feel the same level of security as before. The two studies by Newlink and Centro Juan Montalvo, published the same year, show different results. This may be 
attributed to the areas in which they were conducted, and the two studies may not be completely comparable. Even so, the results highlight the challenges faced by these programs and the different levels of success they have been able to achieve in the shortterm.

In a study conducted by Newlink Political for the Secretary of State of the Interior and the Police (2007), a sample of men and women ages eighteen and older was surveyed in sixteen neighborhoods in the Distrito Nacional. The sample size ensured that an equal number of people from each neighborhood was included. The Distrito Nacional consists of the suburban neighborhoods around Santo Domingo. The study was intended to capture any progress made by PSD after another year of implementation and in additional areas.

The first question asked respondents to identify the principle problems facing their communities. The top answers given were the lack of electricity, crime, lack of drinking water, drugs, pollution and a lack of garbage collection, flooding, the condition of the streets and highways, unemployment, and corruption. Note that the majority of those identified are structural problems within the country rather than direct law enforcement issues or specific crimes. In most of the barrios, fewer than $50 \%$ of respondents felt that drug traffic, sales, and consumption had increased or remained the same in the previous 12 months. The response was roughly the same when asked about levels of police corruption. More than half felt these problems had actually decreased. Despite this, the people surveyed had a generally negative or neutral opinion about the parks and organized community activities in their neighborhoods, indicating no real improvement in the areas outside law enforcement that PSD claims to address. The same 
was true for the activities of health institutions, police patrols, and the church, though in many cases a number of people preferred not to answer these particular questions. This refusal to answer might be interpreted as a lack of trust in the survey and the anonymity of the answers given. This phenomenon is also captured in several of the other surveys discussed below.

When asked about their feelings of security, most were more positive about it between the hours of 6 am and $8 \mathrm{pm}$, and definitely more negative from $8 \mathrm{pm}$ to $6 \mathrm{am}$. The proportion of respondents who had been the victim of a crime or whose family member had been the victim of a crime in the previous year was only $27 \%$ in the worst case. In some neighborhoods no one claimed to have been a victim of crime at all. The most common type of crime mentioned was a theft like pick-pocketing or pursesnatching. While some reported the crimes to the PN or local police station, just as many did not and in some cases more did not. When asked to explain why, more than half said it was because they did not have any confidence in the authorities despite the perception that corruption had decreased, as indicated above. Corruption may have diminished but it had not been eliminated enough to increase confidence in the institution overall.

Between 62 and $96 \%$ of respondents said they did not know the police officers who patrol their neighborhoods, and 27 to $85 \%$ said the police do not treat them with courtesy and respect. These numbers paint a different picture than those from the survey of police personnel as described earlier. It seems the police at the national level have a better perception of themselves, or that these neighborhoods in particular have a worse relationship with the police. About half of those surveyed said the police do not do their job well, though fewer than half believe the police abuse the authority they have. In all 
cases, at least half and up to $85 \%$ said the police do not use excessive force, but the majority noted that police do not treat everyone equally.

A majority said the police patrol their neighborhood either an average amount or never. In only a few cases did the majority say the police patrolled frequently. More than half said they know of no other activity the police actually do in their neighborhoods. More than half said the police give them a feeling of security or protection, though in some cases a third or more said they fear the police. This can be taken as an indicator of inconsistent police practices, or lingering corruption and abuse of authority in some areas.

About half of the respondents said police do an average job controlling crime. Low salaries was selected by $63 \%$ of those surveyed as the main reason the police are not doing their jobs as well as they could be. Lack of honor and corruption were the next most popular answers. Interestingly, the top suggestion for how to improve police work in the neighborhoods was to increase the number of patrols. This was selected by $62 \%$ of those surveyed. In no case was an increase in salary the number one choice.

In spite of the fact that so few residents know their local police, there was no overwhelming support indicated for the idea of having permanent assignments for officers in the neighborhoods. This idea received between 8 and $58 \%$ of responses, while rotating officers received 35 to $73 \%$ in the various neighborhoods. No more than $19 \%$ of respondents in any particular area said they had sought police help or information in the previous six months, and no more than eight percent had reported witnessing a crime. There was in general a low level of interaction with the police - good or bad. 
The majority answered yes to the question of whether the police are helping with solutions to citizen security, but there was no consensus on the quality of the work the police are doing to control drug traffic. A majority said bad, very bad, or average, though in some cases up to $35 \%$ said good or very good. It is important to note that in certain areas, drugs are considered a problem needing urgent attention; in only one of the 16 neighborhoods included in the study did people think the problem had diminished. A large majority (up to 96\%) said they do not know anyone involved in drug traffic and that drugs have not affected their lives or families directly. The study states that in the majority of the neighborhoods people have been offered drugs, which is important even if the percentages are low because it indicates that drugs have infiltrated everywhere, as have the gangs associated with the trade. Those who said there are gangs know their names, recognize the members, and say they are involved primarily in the sale and consumption of drugs, robberies, and creating disorder in the neighborhoods.

As for the perception of how crime and disorder are dealt with, a majority of those surveyed know little to nothing about the criminal procedures code in the country. They think the police know a lot about it and that others in the community know some or a little. Less than half view the code as something that exists to protect victims. Many more think it helps criminals: "Los delincuentes se esconden bajo las garantias que brinda el codigo procesal penal" (Newlink, 2007: 129). They believe criminals can hide behind the protections the code provides and that it favors them over the victims of crime.

The PSD is almost completely unknown amongst this sample. More than half of those who do know something about it had no response when asked what they hoped it could do for them. Fewer than 50\% were familiar with Barrio Seguro and gave a wide 
variety of answers about what they hoped it could do for them, such as provide more security, reduce crime, improve life, bring more patrols, reduce drug traffic, and help the community. This shows some improved perception but again it is difficult to assess the direct impact of the program in the short term.

Similar to previous studies, another Newlink study of the PSD from May 2008 analyzes perceptions of security and victimization among the population in the neighborhoods that are a part of the Barrio Seguro program. The randomly selected sample included people ages eighteen and over, both men and women, of all socioeconomic levels within nine selected areas of Santo Domingo and Santiago. This is an additional effort to evaluate the impact of the program after yet another year of implementation.

When asked what the fundamental problem is that needs to be solved in order for there to be more security in the neighborhood, the top three answers given were street crime, lack of police vigilance, and drugs. In this open-ended question, these same three responses were the top as a first answer given, as well as in the totality of answers. There is little mention of the broader structural problems named in prior surveys, which may indicate that crime has risen and remained acute.

When respondents were asked if they were familiar with PSD, nearly $73 \%$ said no. This number was not significantly different in areas where PSD and Barrio Seguro had been started in 2005 versus 2006 or 2007. It is surprising considering the program had been around longer by then and the program's institutions and leaders could have taken the opportunity to raise awareness and educate the public. In spite of this lack of knowledge of PSD, 94\% did say they were familiar with Barrio Seguro, and 42\% said it 
is a good program. An additional 19\% called it average while 13\% said it is very good. Only $10 \%$ said it was bad or very bad.

Half of the respondents said that fear and insecurity among the populace had diminished since the implementation of PSD and Barrio Seguro. When asked about levels of confidence and trust between the police and the citizens, $39 \%$ said it was the same but $24 \%$ said it had increased. Similarly, $41 \%$ said relations between the police and the community were the same but $25 \%$ said they had improved. Yet in half of the areas surveyed, $50 \%$ or more said fear and insecurity among the population had increased or remained the same. Responses were also mixed for confidence and trust between the police and citizens. Between 16 and $61 \%$ said it had increased, 25 to $50 \%$ said it had remained the same, and 4 to $44 \%$ said it had actually diminished. These numbers show some inconsistency in the implementation of the program in different areas, that inconsistent outcomes are likely the result of greater challenges in some neighborhoods, or that improved relations between the police and the community alone are not enough to reduce crime and increase security.

The majority of respondents said that the participation of the community in matters of security had increased or stayed the same. No more than $36 \%$ said it had decreased. The numbers regarding relations between the police and the community are similar. About half said that public institutions and the community working together had increased or stayed the same, though anywhere from 7 to $50 \%$ of respondents said it had diminished. In Santo Domingo Este for example, $50 \%$ of respondents agreed this relationship had diminished while $29 \%$ either said they did not know or gave no response at all. This leaves only about $21 \%$ to agree the relationship has improved or remained the 
same, a discouraging result since the goal of PSD is to bring the community and the institutions closer together - the opposite of what this data seems to indicate has happened.

When asked if they, or the organization that represents them, participated in some project of PSD and Barrio Seguro since the start of the program, 93\% of respondents said no. Sixty percent of respondents said that they personally do not participate in or belong to any organization. Of those who said they do, $23 \%$ (the largest group) belong to a religious organization. When asked how an effective citizen participation can be obtained in the security problems of the neighborhood, the top answers were to unite or bring together the community and the authorities (22\%), to call meetings and invite the community (20\%), and do not know (18\%). The obstacles to participation named by respondents were having never been summoned or invited (75\%) and a lack of time (17\%). It seems that perhaps more people would get involved if there was a mechanism by which to recruit more of them. It does not appear that many feel compelled to volunteer their time or are even aware that there are ways for them to be involved in projects in the community.

Since mixed patrols began in the neighborhoods, $57 \%$ of those surveyed said crime has diminished, though only one-third give this response in the area of Santo Domingo Este. When asked if they know the police officers who patrol their neighborhoods, $71 \%$ of respondents said no. Again, there was some variation across geographic areas. In one part of Santiago nearly 50\% said no, while in Santo Domingo Este, more than $90 \%$ of respondents do not know their local patrol officers. This is likely related to the attitudes reflected in this and prior surveys about permanent assignments 
for police officers. Some in the higher crime areas may prefer not to know their officers. They may be more likely to see a familiar police officer not as the friendly neighborhood civil servant but as an entrenched participant in local crime and corruption.

About $36 \%$ of those surveyed said that the police treat residents with courtesy and respect, while about $29 \%$ said they just barely fulfill their obligations. An additional 17\% believe the police abuse their authority, and 19\% did not respond or did not know. When asked if the police use violence, $32 \%$ said rarely, but about $30 \%$ said frequently or the majority of the time. In one sector where nearly $55 \%$ said the police rarely use violence, $25 \%$ still said frequently or the majority of the time. In only two areas did as many as 30 or $40 \%$ say never. Equally telling and troubling is that in Santo Domingo Este, the top answer was do not know or no answer at all. This may be another instance or indication of a lack of trust in the survey and a lack of confidence about the anonymity of responses in an official survey of any kind, or a lack of police presence that would make any impression on the residents. Whichever the case, it appears to be an indication of a problem.

In the five areas surveyed in Santo Domingo, more than half the respondents said the number of patrols had increased or remained the same as a result of Barrio Seguro, but in Santo Domingo Este, the top answer was "there is no Barrio Seguro program," followed by do not know or no response. In Santiago, nearly $46 \%$ said patrols had decreased, and about two-thirds said police never or rarely patrol the areas where young people congregate, where the gangs are, where the most conflict is, where drugs are sold, or where the most assaults occur. In other words, police officers are not taking the 
initiative to do their work where it is most needed. They are not visible or making an impact that is noticeable in some areas.

When asked what other activities besides patrols the police do, $52 \%$ said none and $27 \%$ said do not know or gave no response. These two options combined were slightly higher in all four areas of Santiago as well as in Santo Domingo Este. When asked to qualify the work done by police controlling drugs, $30 \%$ said good, $32 \%$ said average, and $31 \%$ said bad. About 10\% more in Santo Domingo Este and one area of Santiago said bad. Respondents were similarly split on whether or not police are involved in drug sales, with 36\% saying yes, $30 \%$ saying no, and 34\% saying they do not know or not responding at all. Respondents were divided again when asked whether or not PSD and Barrio Seguro have had any effect on drugs, with nearly $34 \%$ saying yes, $30 \%$ saying no, and nearly $37 \%$ did not know or gave no response, although there were three cases in Santo Domingo where as many as 47 to $55 \%$ said yes, PSD and Barrio Seguro have had a positive effect. By the same token, in Santo Domingo Este, $74 \%$ of respondents did not respond or did not know, and between 37 and 46\% in Santiago said no. Again, we can discern the limited ability of these programs to make an impact in the most crime-prone areas in the short term, and the reluctance of many residents in these areas to go on record about these issues.

When asked about what feeling the police inspire in them, $42 \%$ of respondents said security. This percentage was as high as $63 \%$ in some cases. Protection and fear received $26 \%$ each. Security received the highest percentage of responses in all areas surveyed except for Santo Domingo Este, where 33\% said fear (the most popular answer), and 31\% said security. Only four percent separated the responses of security 
and fear in one area of Santiago (36.4\% vs. $32.6 \%$, respectively). This is likely an indication that in some areas of the cities, the police still have a reputation for violence and corruption, and are still engaging in practices to earn them this reputation.

When asked for suggestions about how to improve police work in the neighborhoods, the most popular answers were hire more police officers (21\%), raise police salaries $(21 \%)$, training $(20 \%)$, and rotation $(10 \%)$. When asked if they prefer to have designated, permanent police officers assigned to specific areas or officers that rotate, $63 \%$ overall, and up to $81 \%$ in some cases, said rotate. When asked to explain why, $60 \%$ of respondents said rotation does not allow for relationships to develop between officers and criminals, which is consistent with prior surveys.

The people surveyed were also asked if they had heard anything about the new Penal Process Codes. Overall, 42\% said they had heard nothing and 40\% said they had heard a little. No more than $26 \%$ in any of the neighborhoods surveyed said they had heard a lot. Two-thirds of respondents think the code favors criminals over victims: $38 \%$ agree and 30\% strongly agree. Half think criminals can hide behind the guarantees the code offers them: $48 \%$ agree and $2 \%$ strongly agree. This is again consistent with previous surveys.

When asked if the code protects victims, $33 \%$ disagree, though $38 \%$ agree that it helps the police and the administration of justice in general. In spite of that, $62 \%$ do not think the police are capable of properly implementing the code, but $71 \%$ do think that the police are capable of collecting evidence and $69 \%$ think they are capable of completing a criminal investigation. This does appear to be some improvement in the perception of police capacity since the code was introduced. Those surveyed were split 50/50 on 
whether or not judges apply the code correctly. Sixty-percent think judges are too permissive and $65 \%$ said the public prosecutors let criminals off the hook. ${ }^{8}$

When asked if, since the start of the Barrio Seguro program, they or anyone in their families had been the victim of a crime, $70 \%$ of respondents said no. This percentage was as high as $93 \%$ in one area of Santiago. Twenty-six percent said they reported these crimes to a local police station and 21\% reported them to the PN, but $47 \%$ said they did not report the crimes at all. This high percentage - consistent with other surveys - indicates a continued lack of trust in the police despite reform efforts aimed at creating closer relationships between the police and the community.

Newlink finds the results positive overall and concludes that "this positive evaluation [of various PSD programs] calls for continuing to implement the programs, but for strengthening and spreading them out in a more efficient manner among all the communities so that there is a larger number of beneficiaries" (Newlink, May 2008:

n.p.). The results of the survey indicate very limited participation by the community in matters of security, and the report argues that this is unfortunate considering that one of the objectives of the PSD is to incorporate the community into its programs. While there are some positive results, many areas for improvement have been revealed by the survey. One might argue not only for strengthening and spreading the program to all areas but for strengthening and reworking them in the areas they already exist but have had the least positive evaluations (i.e.: Santo Domingo Este).

Of all types of crime, drugs are perceived to have increased the most and there is no definitive opinion among the people about whether the PSD has helped. The image of

\footnotetext{
${ }^{8}$ An article published in El Caribe on January 8, 2008 supports this perception by noting that about $42 \%$ of accused drug dealers were released by the courts.
} 
the police has improved in most areas with the implementation of the PSD and the police presence in the neighborhoods has contributed to an improved perception of security in general. Sixty-seven percent of the population surveyed felt some confidence in the police though $26 \%$ still said the police make them fearful. The impact of PSD and Barrio Seguro programs on public opinion of the police is nowhere near as dramatic or revolutionary as the police chief would have us believe, though this is not to say that there has been no improvement whatsoever.

In spite of some increased security and confidence, there is still a lack of integration of the police as a part of the community. Few citizens know the men and women who patrol their neighborhoods - and few seem to want integration. A preference for rotating police assigned to the neighborhoods is consistent with previous surveys, reflecting a desire that individual officers not be attached to any particular area. More than half the people agree the police act with violence rarely or never, and:

This is significant because it demonstrates an evolution in respect to the application of violent practices of the past, which is to say that the process of reforming the institution is having positive results on current police practices toward the community (Newlink, May 2008: n.p.).

Still, in some areas fear of police persists, whether it is explicit in the survey answers or indicated by those who refused to give answers at all for certain questions. Police work on drugs is not well-perceived and many still note the complicity of police personnel in drug transactions in particular.

The final external evaluation examined here is one written by Newlink in June 2008 as an overall assessment of all their prior research, surveys, and focus group studies on the efficacy of the PSD and Barrio Seguro. Newlink uses this data to determine the 
successes as well as the challenges to the programs to assess whether they have been efficient and effective, and if they will be sustainable in the longer term. These questions are particularly important for those programs affecting citizen rights and democratic culture. By the time of the evaluation, 101 neighborhoods had been a part of PSD programs, all of which were in Santo Domingo or Santiago.

The evaluation finds a correlation between people's assessments of Barrio Seguro and the date of its implementation in their neighborhoods. This assessment is poorer in places where the program began earlier - the opposite of what one might expect, and certainly not what was intended. This pattern holds in both Santo Domingo and Santiago. In Santo Domingo Este, nearly 35\% of those surveyed could not give an evaluation of the program at all (also the most frequent answer). This could indicate that the program has not had any relevant impact in these neighborhoods. The report suggests that the program lost its impulse or momentum in the second year when it was expanded to additional areas. Some institutions were unable to fulfill their duties and thus the people's expectations could not be met. Early positive results caused too much expansion too soon without adequate resources, and the results could not be replicated.

Regarding police reform, Newlink says concrete action has been taken to make the police force more effective and efficient in preventing and controlling crime, but so far that has not been sufficient for making profound changes or having a positive impact on citizen security. The reform process has changed direction and leadership at least three times, which has meant corresponding changes in strategy and personnel, all of which have caused reform projects to move backward or remain stationary rather than moving forward. "Police reform remains the greatest challenge for the PSD" (Newlink, 
June 2008: 34). Indeed, the recent scandal in Baní demonstrates the extent to which corruption has affected not only the police but also the DNCD and the military, and how reform in two of the largest cities in the country has not been able to influence drug traffic elsewhere, other than to move it into areas where the program does not yet reach.

Despite these challenges, there have been some significant advances that indicate concrete steps in the reform process. These include the development of an institutional structure that is more able to keep up with modern criminality, the obtainment of modern equipment, and the additional training of personnel with the objective of improving service to the community. Efforts have also been made to dignify and improve the image of police work as a career, and to purge the ranks of corrupt officers. It may be tempting to label these mere drops in the bucket but it is also too early in the process to dismiss them outright.

Newlink's analysis of surveys of the general population and institution employees, of changes and actions undertaken, and of crime statistics shows that the PSD, and especially the Barrio Seguro program, has had an "unquestionable impact" on communities participating in the programs, as well as on public institutions, and for promoting a change of attitude toward security as the responsibility of all (June 2008: 37). Unfortunately, while levels of violent crime had begun to drop from the time the program began, the data available in mid-2008 indicated another increase. Indeed, the number of people killed in an exchange of fire with the police is worrisome (Newlink, June 2008). The evaluation suggests this increase in violence during the first half of 2008, despite the decline during the first two years of PSD, is evidence of the extent and strength of organized crime and drug trafficking networks in the country. It may also be 
a problem of the capacity and sustainability of the program. The effort and ideas are right but the actual man-power available is not sufficient to meet the level of the problem, nor are the program and practices well-enough established yet to call them successful. In spite of the fluctuating crime statistics, the report says that public perception of security has improved and that crime in general has decreased as a direct result of PSD programs. Improved perceptions of security notwithstanding, "the perceptions of the inhabitants of the neighborhoods participating in Barrio Seguro of the police in their neighborhoods continues to be poor" (Newlink, June 2008: 45). But where Barrio Seguro has been operating longer, there seems to be slightly greater acquaintance and closeness of the people to the police. The worst assessments in Santo Domingo Este are attributed to the very short time that police have been assigned to and carrying out patrols there. After longer times, the report finds more people give positive evaluations of how the police relate to the community, and claim that one can see favorable changes in the way the police behave in the community. Some negative evaluations of patrol efforts can be attributed to the challenge of maintaining enough officers to do them while simultaneously completing the process of purging the ranks of corrupt individuals. This process has clearly created shortages in some areas. It can also be seen as a growing pain of the reform process - but a necessary one.

Drugs and drug crime remain a problem. The evaluation finds that the number of people who see little or no improvement in drug control is an indication of the minimal impact police work is having; $63 \%$ of respondents in the surveys say the work done by police in this area is either average or bad. As one focus group member put it, the police will not even go into the places where people are selling drugs. The number of people 
who believe the police are involved with drugs in their neighborhoods is also worrisome, especially since most of them are afraid to speak out against it: "Here there is no security for those who go to the police and that's why drugs keep accumulating in our country...that's why there is no progress against drug traffic" (Newlink, June 2008: 50). Just over a third of those surveyed say police are involved in drugs, and the evaluation says that this proportion has dropped - especially where PSD has been operating the longest. And yet there are still an equal portion of do not know/no response answers in all cases. Plenty of people may still be afraid to put their opinions on the record. The neighborhood public attorney's offices are "responsible for guaranteeing citizens access to the system of justice" but the perception that the system lets too many criminals go free also persists (Newlink, June 2008: 52). The evaluation points out that there are good reasons for this which are basic to the system itself. The new system is working to apply the penal code vigorously and thus it depends on evidence and legality. There are a series of conditions and regulations that must be adhered to and respected by police officers and others in order to arrest, detain, and investigate cases legally and properly. This procedure is clearly the norm in a democratic system but has not necessarily been the norm in the Dominican Republic. The public is likely to need time to adjust to the new process - and see it actually work successfully - before negative perceptions will go away.

\section{-- Personal Interviews --}

Based on her research, Dr. Rosario Espinal of Temple University confirms there has been some drop in crime in the Dominican Republic between 2006 and 2008. She 
also suggests that the major criticism of the Barrio Seguro program is that regardless of its stated goals, it does not address the main underlying problems that contribute to criminal activity within society: poverty and lack of education. She told me that police programs may be successful at reducing crime in one area but that crime relocates to another where the programs have not yet been put in place, echoing all the literature on the balloon effect of drug control policies. Finally, a program like Barrio Seguro, whether it is effective or not, is a way for the government to show it is taking some kind of action.

Bielka Polanco of Newlink describes gangs in the Dominican Republic as both an old and a new problem. Most of the crime committed by these groups is drug related, and has increased significantly within the last ten tears. More recently, crime has been controlled, though not always by the best methods (Polanco, 2008). A number of gang leaders have been put in jail or killed by the police. This latter method is unofficial and yet the general public knows what extra-legal methods have been used to remove criminals from the streets (ibid.).

Ms. Polanco believes that the gangs have reorganized themselves in response to the Barrio Seguro program. One perception of the police that is related to this reorganization is that they are paid by the gangs to look the other way and provide protection for them. The gangs have reduced conflict amongst themselves and Barrio Seguro provides the semblance of security in the neighborhoods even if the amount of drug traffic has not diminished. Barrio Seguro has provided a cosmetic fix she says. In other words, as Dr. Espinal suggested, the program gives the image of government action even if the results are dubious. 
According to Ms. Polanco, police reform has not been institutionalized but has instead proceeded on a personal basis led by the particular chief in charge. Police salaries are low, but the institution provides some incentives through opportunities to specialize, such as Barrio Seguro. There has been some effort to create schedules so that officers can have other jobs, but the ranks are still heavily susceptible to corruption because of low wages. The traffic police, AMET, have slightly higher salaries and this has helped relieve corruption somewhat. Ms. Polanco said she would not offer a bribe to an officer who stopped her in her car, but that even five years ago one could easily attempt to avoid tickets that way. At the same time, low salaries are a problem in most sectors in the country, not just for the police, making drug money attractive to many more widely. For example, a study by Centro Juan Montalvo found that the average monthly income was $\mathrm{RD} \$ 12,435$ (approximately $\$ 343$ US) but about $70 \%$ of workers actually earn less than that average (DR1 Daily News, August 6, 2007).

Recent reforms to the criminal code have emphasized human rights and the rights of detainees. The public's perception of the code is that it gives more rights to the accused. People want stronger measures, or mano dura, for dealing with criminals (Polanco, 2008). The problem according to Ms. Polanco is with the implementation of the new code, rather than with the code itself. The system is not prepared to properly execute the things required of it and the people involved need more training. Often the police themselves claim ignorance of the new code, which may very well be true in some cases. The fundamental issue of course is that if the police do not follow the procedures, then the public attorneys cannot prosecute. As the first step in the justice system, the future processing of all cases hinges on correct handling by the police at the initial stages. 
There is also a certain amount of ignorance of the new code on the part of the public. People may see the police working and place blame on the judges or attorneys for problems in the system. Police also blame a lack of action on the part of judicial authorities as a cause of continuing crime and increasing vigilantism (see for example “Chief of police blames justice for lynchings," DR1 Daily News, August 4, 2008). Reform is a process and it will take many more years before significant progress is achieved. The most challenging area for reform will continue to be internal affairs and police discipline.

On that topic, anthropologist Dr. Tajira Vargas says it is an old and common practice for reports in Dominican newspapers to say that criminals, especially suspected drug traffickers, were killed in an "exchange of fire." In reality, she says, the police intentionally kill these suspects and the public knows it. Dr. Vargas also notes this kind of action by the police has gotten worse rather than better in recent years, and it has become more common for the authorities to injure and leave behind other young victims in the process. These kinds of incidents are rarely if ever investigated by the police. In addition, many officers do not see the judicial process as necessary when they can handle suspects in this manner instead, which then sets an example for the citizens to take the law into their own hands (Vargas, 2008). In other words, a democratic judicial process is not seen as necessary, valuable, or expedient.

Dr. Vargas is not optimistic that the situation will improve, but suggests that strategies must change and the entire jefetura or leadership and its structure must also change. There need to be definite sanctions within the police for violations of human rights. She says the government needs to regulate the police even more than they do. 
She does not trust the police and believes most Dominicans do not either. It is still common practice to offer bribes to police officers, though she agrees with Ms. Polanco that this is less true for the AMET. ${ }^{9}$

Dr. Vargas claims that local police officers receive as much as 20,000 pesos (approximately $\$ 550$ U.S.) each week to allow drug traffic to continue. Military checkpoints along the country's borders typically receive 300 pesos per bus wishing to cross. Indeed, investigative reporters Minerva Isa and Eladio Pichardo reported extensively on this topic in Hoy during July 2009. Other types of crime can also be excused with similar payments. This money works its way up through the ranks within the police system - bribes are not confined to patrol officers. Dr. Vargas argues that the current scandal surrounding the government purchase of the tucanos airplanes is an example of the way that those within the government and at the highest levels can be paid off as well. She, like others, asks where the money for such a purchase actually came from.

The United States aids Dominican efforts in the war on drugs by providing more guns to the military and the police, but this is a pantalla. It is a screen or a cover; as both Dr. Espinal and Ms. Polanco suggested with Barrio Seguro, it is a way for the government to make itself look good by providing some kind of effort. Dr. Vargas is not convinced there is truly a method or a particular group that can effectively control drugs in the country. The primary sources of drug crime are now the microtraffickers. Larger

\footnotetext{
${ }^{9}$ Listin Diario noted that bribery is a way of life in the Dominican Republic, citing a study conducted in three provinces - La Vega, La Romana, and Peravia -- that revealed $71 \%$ of the population believes that "macuteo" - Spanish for small bribes - takes place in the Attorney General's office and that corruption and extortion practices are commonplace (November 30, 2007).
} 
shipments are the focus of government programs, and shipments are often seen entering the country, yet few ask where they are destined. How to control and follow through on the subdivision of major drug traffic into and through smaller organizations is the question that is not being asked or adequately pursued (Vargas, 2008). ${ }^{10}$

The most serious problem facing the Dominican Republic is structural: electricity and flujo de servicio or inconsistent service. Power outages have negative effects on the entire economy and individual security. Equally important are problems with the educational system. For Dr. Vargas, both of these affect everything else and contribute to insecurity. Community organizations are primarily formed to address issues like education, electricity, and neighborhood security rather than human rights abuses. Most people do not like to speak out against the police. There is still much fear of the repercussions and this fear impedes the development of civil society and real citizenship.

The Dominican Republic continues to have a high level of unemployment, and clientelism is still a major factor within the government. Vargas says the level of democracy in the country is extremely low in part because there is no sector of the government that is under the control of the citizens. Most people are not even aware of their rights and what citizenship is. Many are ignorant of the tax system, state monies, and how the system functions. Institutionalized corruption is the norm and seen as fine by many - and so the killing of criminals by the police is thought to be a good thing. As

\footnotetext{
${ }^{10}$ President Leonel Fernandez announced on August 13, 2009 he was declaring war against the microtrafficking of drugs. Diario Libre says that the DNCD has pinpointed 19,000 of the micro-positions for distributing drugs nationwide. The goal is to dismantle the sales points. Fernandez wants more aggressive action against drug dealers by the state's security organizations. The President also promised to create new job opportunities for youths. The President says the micro-traffic is the principal threat to Dominican youth. DR1 Daily News, August 14, 2009.
} 
for new police trainees, Vargas says the institution will adjust and the culture will eventually absorb them. New ideas might be introduced but old practices will remain.

\section{$\underline{\text { Conclusions }}$}

The various reports and surveys analyzed here provide a picture of some of the achievements and progress made by the PSD and Barrio Seguro programs toward the goal of improving citizen security and professionalism within the police. They also show that whether you are inclined to interpret the data in an optimistic or pessimistic manner, there are clearly still areas in need of further improvement. Unfortunately, the latest news reports also point to little advancement in the longer term and perhaps even some movement backward. We need to be concerned about the number of violent deaths still occurring - up to 959 during the first five months of 2009 alone (DR1 Daily News, July $20,2009)$, the continuing sentiment that the programs and the institutions involved are not working (DR1 Daily News story “'Safe barrio' residents complain of crime,” June 9, 2009, and "The police reform that wasn't," Hoy, June 18, 2009), and the rise of vigilante justice (see articles DR1 Daily News, June 2, 2008, June 19, 2008, and August 4, 2008). Even as some progress has been documented in certain cases, the problem is still much larger than the efforts to address it.

Where basic services are few, there also exist "a series of social problems like criminal and domestic violence, drug addiction, alcoholism, teen pregnancy" and so on (Newlink, June 2008: 16). The PSD was created to address these by providing "educational, sports, cultural, and work opportunities, and promoting participation of the community in the development and security of their communities" (Newlink, June 2008: 
16). At the start of Barrio Seguro, the level of community participation was very low. Many people did not consider community involvement to be a fundamental part of citizen security. There were also few opportunities for participation, and those groups that did exist were not very inclusive.

With the PSD the people in the areas involved have opened themselves to the idea that community participation is a means through which to gain security, and that as subjects with rights and obligations to that security, the members of the community have much to contribute and reason to be involved. Even so, this is an incipient or fledgling idea, not yet well ingrained or accepted as true. Only about 19\% of the people interviewed by Newlink overall had been invited to participate in meetings discussing security issues. In some areas, citizen participation has gone down since the beginning of Barrio Seguro, and while people may be interested in becoming more involved, often there is no opportunity to follow through or programs have lost their momentum over time.

Low levels of recognition exist among the public about which institutions were actually a part of PSD, aside from the police and a few others, and there were frequent complaints among those interviewed about minimal or weak participation by certain public institutions. As one focus group member said, "Barrio Seguro is only known for its repressive elements. Other things like health and education are hardly noticeable" (Newlink, June 2008: 27). We might see this criticism as a symptom of state desire to deal with domestic and structural issues broadly while answering to international pressure to deal with crime specifically. The program promises wide-reaching reforms and opportunities, but the punitive measures are the most prominent and visible. 
An increased presence for the state is not just about police reform or creating a larger police force. Police-focused efforts must also be integrated with all other kinds of government programs that comprise the PSD and contribute to increased feelings of security overall. These are the programs aimed at providing adequate food and health care, improvements in education and housing, and providing ways for the people to feel that they have a stake and a role to play in the reclaiming of public space.

The emphasis in political reform in Latin America has been on decentralization, "returning to the local level as the ideal place to bring the government closer to the people" (Morgan et al., 2006: 105). Ideally, the object is to increase citizen participation, with the assumption that this increased citizen participation means more efficiency in public administration, thus increasing the possibility of authentic democracy. To what extent the PSD and Barrio Seguro programs are truly forms of political decentralization is up for debate. The programs aim to bring the state's presence back to all areas of the country and in effect re-centralize the population by bringing them into the institutions of their communities. The community police and patrols that make up the Barrio Seguro program can be seen as local, decentralized components of a new central state presence through the same program. Whether this strategy will improve civic engagement, democratic participation, and the rights of all still remains to be seen.

In the meantime, the mixed results of the programs, particularly the continuity of a preference or tolerance for repressive and extra-legal measures for dealing with criminals, do not appear to support our notions of justice in the war on drugs. Some improvement in the police profession bodes well for maintaining the Dominican state as a legitimate authority in the war, but at the same time, drug crime, corruption, and the 
violent measures undertaken by both police and private citizens come at a cost to

democracy. The necessity of suspending these norms has not been justified by the same evaluations of these programs which are beginning to show that measures short of war may still have some positive effect. 


\section{VII: Discussion}

The preceding chapter demonstrated the ways the state has tried to increase its presence in Dominican society, to reduce crime, and to reform the police. The goal was to improve perceptions of the institutions and to protect citizen rights and security. This final chapter briefly discusses how these efforts have affected citizen security, civil society, and the quality of democracy for all. I then revisit the discussion of justice in the war on drugs to see if and how the effects of the war have undermined its own goals or violated the principles of a just war. Finally, I discuss the positive outcomes and possible future directions for continuing the drug war and its related reform programs.

\section{Security and Democracy}

"The opinion that democracy is preferable to other forms of government remained stable in the last decade, above 70\%, even despite the 2004 crisis. Nonetheless, a preference for order has also retained a consistent and important degree of support, even if it means there might be less democracy" (Morgan et al., 2006: 59-60, emphasis added).

The percentage of people in the Dominican Republic who felt unsafe rose from $42 \%$ in 1994 to $79 \%$ in 2006 (ibid.: xi). The number who reported being a victim of a crime doubled from 2004 to 2006 , and $70 \%$ of the people think the police are involved in crime. This assessment is supported by continuing reports by news outlets on such incidences as the arrests of military officials who are involved in drug traffic, and about drug manufacturing operations that exist within the same building as police stations (Diario Libre, October 6, 2007). It should come as no surprise then that "the percentage of people who support acting outside the law to capture criminals [has] increased" and "people who feel unsafe show a greater propensity to condone acting outside the law to 
capture criminals" (Morgan et al., 2006: xi). This attitude contradicts support for democratic practices and the protection of civil rights within a democratic society, and underscores the young stage of civil society development in the Dominican Republic, as well as the ways that crime and insecurity work against its development.

This begs the question of whether there has been any improvement at all at the end of the time period covered here and again points to the inconsistency of the results of the PSD and Barrio Seguro programs. Recent news articles in the Dominican Press even call it "the reform that never was" and suggest the population feels less secure than before the programs began. Indeed, while Police Chief Santana Paez announced an increase in foot patrols for over twenty neighborhoods as of July 2007, and Interior and Police Minister Franklin Almeyda praised the decrease in crime during the first half of the year, by October Hoy reported that the largest number of officers were employed in the service of high-ranking government officials or the private sector - not on the streets (see DR1 Daily News, July 25, 2007 and September 4, 2007; Hoy, October 10, 2007).

The increase in crime in the Dominican Republic has coincided with a decreased capacity to deal with it. As a result, "the percentage of the public who favors acting outside the law to capture criminals rose" (Morgan et al., 2006: 96). In fact, the proportion of people who support the idea of acting outside the law to capture criminals nearly doubled from $23 \%$ in 2004 to $41 \%$ in 2006 (ibid.). This view can be correlated to people's conceptions of democracy, as described in the preceding chapters, and we see that "people without any clear conception of what democracy means... are equally disposed to permit acting outside the law to capture criminals as people with normative visions of democracy" (ibid.: 99). This indicates that even these normative values 
cannot stand up to high levels of crime and insecurity, and thus security becomes more highly valued than freedom. The development of a functioning system of justice that respects the rights of all is less of a priority when personal safety is thought to be at risk. Democratic ideals are less well connected to individuals and their day-to-day practical lives.

"In a country where the vast majority of people consider crime to constitute a threat to the nation's future, it is important to have a functioning system of justice to combat this problem and improve perceptions" (Morgan et al., 2006: 95). So it is "worrisome that the survey captured a decline, between 2004 and 2006, in the public's perception of the judicial system's capacity to address the crime problem" particularly since it was during this same time frame that efforts were begun to improve those institutions (ibid.). The "data synthesize the violent turn that has occurred in Dominican society and the anti-democratic attitudes and the lack of trust that this situation has started to generate" (ibid.: 104). This then begs the question once again of whether or not the situation is better or worse than in 1996. It also makes the future of reform efforts and additional development of civil society and democratic practices uncertain at best. If the capturing of criminals and the preservation of security are important above all else, then the measure and definition of justice changes and is no longer reflective of what is written in the constitution and the laws of the country.

Drugs have infiltrated the Dominican government at all levels. No one appears to be immune from their influence. Even the president has been linked to those wanted in 
relation to drugs and trafficking. ${ }^{11}$ Officials claim that no one in government has direct or indirect connections to drug trafficking and that the government's increase in drug fighting efforts should be considered proof of their commitment. Even so, Servio Tulio Castanos of the Foundation for Institutionalism and Justice has criticized the recent purges of the army and police, calling them useless and merely a reaction to unstoppable situations. The state is perceived as a criminal state, which rather than responding to problems has become the principal problem. If the entity charged with the duty of controlling and punishing crime is perceived as complicit in it, then it is no wonder people look to other means to protect themselves.

In September of 2007 the National Human Rights Commission of the Dominican Republic asked the attorney general to order an investigation in to a particular incident where three unarmed prisoners were killed by police. In discussing the case, the head of the investigation characterized the police in general as "trigger happy" (Diario Libre, September 6, 2007). In October 2007, the Minister of the Interior and Police Franklin Almeyda denied there was any lack of control within the police, telling reporters that incidents in areas supposedly under the control of the Barrio Seguro program did not reflect any reduction in the program's effectiveness. Almeyda told reporters that Barrio

\footnotetext{
${ }^{11}$ As reported in DR1 Daily News January 31, 2008, the PRD is asking President Leonel Fernández to explain his relationship with Nelson Solano Guzmán. A Supreme Court document indicates that Solano had ties to numerous mega-projects in the DR at the time of his extradition to the US on heroin trafficking charges. During a press conference held at the PRD headquarters, party general secretary Orlando Jorge Mera displayed pictures of Fernández and Solano together on five separate occasions. Attorney General Radhames Jimenez denied that President Fernández has any links to Solano. Jimenez said that the DR supported and signed the papers on Solano's extradition, and according to him that is enough to prove there is no connection between the two. As of October 8, 2008 a pilot who "occasionally" piloted the Presidential helicopter was dismissed, according to reports from the Presidency. Major General Joaquin Perez Feliz of the Air Force said that Lieutenant Colonel Harold Manzano Garcia was dismissed for "serious proven faults." As reported in the El Castrense website, Manzano Garcia was dismissed for his alleged "ties" to drug dealers.
} 
Seguro "is a process, and we are hoping that the local population and the media will cooperate." The minister emphasized that it was not possible to eradicate crime from one day to the next (DR1 Daily News, October 17, 2007). Even so, the extra-legal measures taken by the police to confront criminals are well documented by the local press. Stories abound of those wounded in "confusing incidents" where officers are indistinguishable from the gang members, and of suspects killed in shoot-outs with police. ${ }^{12}$ On November 29, 2007, Diario Libre reported that in the previous 20 days alone, 39 suspected criminals had been killed during shoot-outs with police. On January 25, 2008, DR1 Daily News highlighted the contradiction between these incidents and police reform programs by running the headline "Barrios not so 'Seguro'" and reported on a study done by the Centro Juan Montalvo questioning the efficacy of the Barrio Seguro program. Jenny Torres, a member of the center's research team, said that the study revealed higher murder rates and criminal activity than what is presented by the police. The story also claimed that if you calculated the homicide rate in 2007 , including murders committed by the police, the rate is $22.5 \%$, higher than before Barrio Seguro was implemented, and that the police are interested in presenting figures without acknowledging the murders committed by their own officers. According to Hoy, police records in Santo Domingo and Santiago show that in December 2007, police killed 52 suspected criminals, and

\footnotetext{
${ }^{12}$ Three people were wounded in an incident that occurred when police officers in Santiago confused plainclothes DNCD agents with a gang of assailants. The DNCD agents were traveling in a vehicle with an improper license plate, and the police officers were also in an unmarked car (DR1 Daily News, October 24, 2007). The National Police announced that two men had been killed during a shoot-out in the Vista de Cerro Alto section of Santiago de los Caballeros. They belonged to a gang that murdered four people in the Pastor section of Bella Vista, Santiago in October. The police spokesperson said that the group members had carried out contract killings and drug trafficking and were wanted for 15 different crimes committed over the past two years (DR1 Daily News, November 26, 2007).
} 
another eight in just three days during the last weekend of January 2008 (Hoy, February

4, 2008).

While in some cases the citizens support police actions against suspected criminals, even without due process, in others citizens do not wait for the police to take action and carry out vigilante justice on their own. ${ }^{13}$ In others still, the community has come forward to accuse the police of using excessive force and unlawfully executing suspects. Both El Caribe and Listin Diario carried the story of the family members of four men shot and killed by police in July 2008 in Santo Domingo Este. Family members said the police shot the four men even after they came out with their hands up. Listin Diario reported that family members admitted to the victims' criminal behavior, but said that was no reason to shoot them "and throw them in the trunk of a car, as if they were dogs." According to police, the suspects belonged to a gang, and the lone survivor of the confrontation with police admitted that he and his friends were part of the gang and sold drugs in the neighborhood. Incidents like these, with clouds of tear gas and multitudes of armed individuals in uniform, certainly invoke an image of a battlefield and the destruction of the enemy as the ultimate goal. It is kill or be killed; shoot first and ask questions later. The rules of law, procedure, and protocol, have been suspended completely by the citizens as well as the authorities. The only silver lining is the

\footnotetext{
${ }^{13}$ For example, a 15 -year old minor and one unidentified man were killed by groups of civilians after they tried to carry out muggings in separate incidents in the Cristo Rey and La Fe barrios in Santo Domingo. The police reported that the minor died as a result of gunshot wounds when together with nine other young men between the ages of 18 and 20, he attempted to rob a man on the street in the La Fe barrio. The police said that the minor and his companions had committed several robberies in the past. Meanwhile in Cristo Rey another alleged assailant died and a three-year old child was wounded in a robbery attempt. The police say that the man who was shot was with a group of alleged criminals on several motorcycles and had taken a gold chain from someone at the intersection. An unnamed passer-by who witnessed the mugging opened fire on the attackers (DR1 Daily News, February 24, 2009).
} 
willingness of some to come together to speak out against these kinds of actions.

Unfortunately, the ability to do just that may now be taken away. ${ }^{14}$

To further add to the atmosphere of war, in September of 2008 Presidential drug trafficking advisor Marino Vinicio Castillo issued a challenge to drug traffickers, saying that if they want a war they can have it. Castillo added that the authorities would not give an inch in the fight against drugs, and that recent crimes were clear signs that drug traffickers have declared war on the Dominican Republic. His statement demonstrates both that authorities are under renewed pressure to act since Senator Wilton Guerrero embarked on his crusade against alleged complicity between government officials and drug traffickers, and that they are willing to escalate the war. If the "enemy" is seen as declaring war, then there are likely to be few restraints placed on the responses to them.

Escalation is also evident in the words of National Police Chief Rafael Guillermo Gúzman Fermín when making a stand against the rise in crime. He has refused to apologize for the deaths of eight alleged muggers in two separate confrontations with the police. Gúzman said that the National Police would "not back down one millimeter" against crime (DR1 Daily News, February 14, 2008). Gúzman denied that the deaths could be considered executions by the officers, adding that executions do not exist in the Dominican legal system. Shortly thereafter, his words were supported and given credence by the leader of the Catholic Church in the Dominican Republic, Cardinal López Rodríguez, who told the nation's police force that the criminals they confront

\footnotetext{
${ }^{14}$ The new Constitution agreed on by the PRD and PLD majority in Congress and the party leaderships includes a clause eliminating Dominican citizens' right to protest against violations of the Constitution or the violation of rules or judicial acts. The change was made on the grounds that citizens "do not have a true judicial or legally protected interest." This means that Dominicans will not be able to protest when they believe that laws, resolutions, or decrees issued by the government are in violation of the Constitution ( $E l$ Caribe, September 30, 2009).
} 
should not be treated with any "pious thoughts" (DR1 Daily News, February 18, 2008, emphasis added). Despite being an opponent of the use of force, the Cardinal said that people who commit crimes do not have more rights than their victims, and therefore police officers, who are responsible for protecting the public, are obliged to go after these criminals in their own territory. Cardinal López Rodríguez said that any society was obliged to put a halt to attempts by criminals to take over through the use of violence. Therefore, police shootings should not be an unexpected response to the number of criminals who are trying to impose their control on the public. With righteousness from a higher authority on their side, police can do whatever they want or need to control crime.

But perhaps it is not all bad news. The newspapers also publish stories that point to some positive steps in improving police work. In September 2007, El Caribe discussed the new tactic of mapping out areas where the most crimes occur as a way of stepping up the fight against crime, as well as the addition of more patrols in these sectors of the capital. In December of that year, the chief of police announced increased patrols during the holiday season, and just after the New Year, Interior and Police Minister Franklin Almeyda confirmed a salary increase for police officers (DR1 Daily News, December 21, 2007, and January 8, 2008). The chief of police also announced a new vacation program and an eight-hour work day for officers, both steps to normalize and professionalize police employment.

The Attorney General for the National District, Jose Manuel Hernández Peguero and president of the Human Rights Commission Manuel Maria Mercedes, have said that every month more than 2,000 Dominicans are arrested during police raids and thrown in jail without justification (DR1 Daily News, June 27, 2008). To counteract this 
phenomenon, and in good news for citizenship, the PN began a new campaign to inform citizens about their rights. The campaign included posters placed in neighborhoods saying:

If I am arrested I have the right to:

- know who is arresting me, where I am going, and why I am being arrested.

- be treated well

- be allowed to talk to a person of my choice or my lawyer

- not answer questions during interrogations

- see the Attorney General immediately

- meet in private with my lawyer.

The poster also explains that if these rights are violated, citizens can call a hotline (ibid.). Awareness of one's rights is crucial to the development and practice of democracy and for improving citizenship and security. These measures to change police work for the better may seem small and may not be extremely affective in the short term, but they do still indicate an awareness by all that something needs to be done and is being done. Most important, they provide at least some role and hope for the public, and show balance in the press's treatment of the topic.

\section{Just War Theory Revisited}

The drug war is a metaphor used to simplify and make sense of something confusing and complex, but the impact of such a metaphor should not be underestimated. "It seems that where the war metaphor was once intended to be interpreted and used figuratively, current drug war trends demonstrate a literal application” (Kraska, 1997: 298). This statement was made over ten years ago but the literal trend continues. The New York Times reported on August 10, 2009 that drug traffickers had been added to the "kill or capture" list in Afghanistan. Where Dominicans once looked the other way when 
ublic but it may reflect another code of ethics and justice in the minds of the citizens.

According to Brian Orend (2006) war is "actual, intentional and widespread armed conflict between political communities," where political community means an entity that is a state or intends to become a state (2). By this definition, neither drugs nor terrorism are appropriate targets for war. Even so, "it tends to be the most questionable wars... which provoke the most soul-searching" (ibid.: 23). While I would hesitate to add the war on drugs to a list that contains the Spanish conquest of the west, two World Wars, and the Vietnam conflict, perhaps this study can still advance some aspect of just war theory and the ways that policy and rhetoric about difficult international issues are formulated and carried out.

The ethics of war and peace has a long history. "Almost all major civilizations... have featured fairly fixed beliefs about acceptable reasons for going to war, and permissible means of fighting it" (Orend, 2006: 9). Just war theory is an example of a comprehensive consideration of both war and peace. Reed and Ryall (2007) see "just war thinking as a dynamic tradition for reflecting on the nature of international society rather than as a set of prescriptions to be rigidly applied to crises" (1). This approach is probably more applicable to the war on drugs since the war is not an acute international crisis but an on-going problem within international society. Diverse thinkers, of various secular and religious backgrounds, who are involved in post- 
World War II discussions show that "the just war way of thinking remains a developing tradition, a method of moral reasoning that has evolved, amidst considerable debate, to meet the political, technological and military challenges placed before it by history" (Weigel, 2007: 20). The late $20^{\text {th }}$ century interest in individual human rights has been part of a resurrection of just war theory which has made it more applicable to questions of international relations and law, academic research, human rights theory, and the work done by human rights activists. Justice in the war on drugs relates to all of these.

"A state resorts to war justly only if it satisfies each of the six major rules: just cause, right intention, public declaration by proper authority, last resort, probability of success, and proportionality" (Orend, 2006: 32). Each of these conditions or rules has been discussed previously, but creating a way to measure and test them in the case of the war on drugs is still illusive. I will address each of these areas below.

A just cause exists when one state is the victim of an armed attack, or when a state is acting on behalf of a victim of an armed attack (Orend, 2006). In other words, a state has the right of self-defense when actual physical violence is inflicted upon it, but "for an international act to count as aggression, it must not merely be objectionable or even damaging to a country's interests" (ibid.: 33). It seems clear then that the war on drugs does not fit this criterion. In spite of Dominican officials' statements that traffickers have declared war, and while there is physical force used by drug gangs or paramilitaries in certain cases, this is technically internal conflict. We see turf wars among drug dealers but we generally do not see an organized attack against the state that merits the deployment of U.S. troops to foreign lands, the attacks against Dominican anti-drug personnel notwithstanding, though these can be categorized as murder rather than war. 
The use of military and law enforcement personnel for training may be justified and effective, at least by the United States' own accounts, but this strategy is also not actually war. The U.S. is acting on behalf of the Dominican Republic, but not in defense against another state. The use of the police and the military within the Dominican Republic may be war-like but insurgency or other domestic level threats are generally not addressed by just war theory. Drug syndicates may be multinational and a part of the violence, but so far just war theory still has not fully developed comprehensive means to deal with these entities. There is cause to respond to drugs, but it seems clear the justification should be as crime rather than as aggressive war.

Intention makes the difference between first degree murder and manslaughter. Unlike just cause, right intention is a subjective matter (Orend, 2006). There may be several different intentions behind the war on drugs, and we may not always be able to tell which ones are the most pure. It is easy to speculate on the supposed motives for the war: Is the United States Government a benevolent leader in the war, or does it seek to maintain control over others through its policy and by extending its military presence beyond its borders? Joint operations in the Caribbean are beneficial and cooperative arrangements amongst various governments and agencies in the region make them run efficiently, but are these states giving up control of their territory in the process? The United States is large and powerful, able to command and direct policy in the region. It may appear that others have no choice but to follow. At the same time, these small states need cooperative efforts to confront the myriad problems that drug trafficking presents, and the generalized lack of resources and control they may have to begin with. 
Public declaration by a proper authority seems straightforward enough: A public declaration must be made to alert citizens, but also to gain their consent and to announce government intentions. The war on drugs has been publicly declared numerous times in the second half of the twentieth century, and possibly earlier. Whether it was declared by the proper authority is another question. It is Congress that officially has the prerogative for declaring war, but perhaps we accept a declaration as official when it comes from the president as commander in chief of the armed forces. The rhetoric of the war on drugs primarily comes from presidents and other officials. Since we can argue that the war on drugs is almost strictly rhetorical, the president's declaration of it would not have to be officially authorized by Congress, except perhaps for the money that is spent on it as a policy. As mentioned earlier, a certain portion of this money is hidden in other budgets and is free from congressional oversight, which makes the war even less public as time goes on.

According to Orend's assessment of Michael Walzer's writing on the subject, there is no such thing as a last resort. And yet, official diplomacy is really not an option when dealing with a criminal organization. The use of some sort of sanctions might be, such as the policies and laws that are cracking down on money laundering and cutting off the chemical supplies used in drug-making processes. These practices are often still accompanied by the use of force. Toleration, legalization, and removal of the profit incentive for illegal drugs are more likely to be considered last resort options. These options could be effective but are less palatable to most people in the U.S. than is the use of force. The full spectrum of options is rarely on the table for consideration in a setting where drugs are purely evil and must be eliminated at all cost. It is "more plausible to 
contend not that war be the literal last resort...but, rather, that states ought not to be hasty in their resort to force" (Orend, 2006: 58). We must consider then whether the current war on drugs began without exhausting other non-violent options first, and which other options might still be considered in the future. The PSD is an attempt to reduce crime by addressing a broad spectrum of issues that cause it. With the right support (i.e.: more than just money and training for the police and military elements), these efforts could be effective at reducing demand for drugs and the need for drug money, and limit the need to use force in the long run.

The probability of success is a traditional criterion in just war theory aimed at eliminating lethal action known ahead of time to be futile. Like the criterion of right intention, it is not officially a part of international law. Orend (2006) contends that this is likely because smaller or weaker countries would have a harder time fulfilling this obligation but they still have a right to respond to aggression. In addition, predicting the outcome of war is nearly impossible and history has shown us many upsets. In spite of this difficulty, the probability of success is still something that ought to be considered by any community before engaging itself and its resources in a war. In the case of the war on drugs, we have considered questions such as whether the costs of operations support the gains, whether the gains accumulate over time, and how we can know if we are winning. Clearly, drugs are still crossing U.S. and European borders, among others, and police corruption in the Dominican Republic remains. This corruption is especially entrenched in the areas where reform efforts have not yet reached, as the Baní case demonstrates. We might also consider questions such as whether the development of functioning democracy and civil society have even been considered as an indicator of 
success in this war. Or if the reduction of drug traffic to the level of a "manageable nuisance" is truly the most realistic goal. Neither appears to have been fully realized yet in the Dominican Republic.

Proportionality is "one of the most contentious and challenging jus ad bellum criteria" (Orend, 2006: 59). It requires calculations weighing expected costs and benefits, which often cannot be measured concretely. How can one know what amount of money freeing the United States from drugs is worth, or how many deaths - criminal or otherwise - are acceptable while working toward this goal? Equally important is to ask how much loss to liberty is acceptable, how to measure the justice within a system, and how the war has affected it. The reform of the Dominican Penal Process Code can be considered a victory, though perhaps only a small step, especially since the new code has not been well-received. At the same time, the giant task of reforming the police and judicial systems of an entire country could easily be seen as proportional to the size of the drug trade - even if some may not see it as a direct attack on that trade itself. Returning to the principle of a reasonable chance of success - and partly to necessity - for a moment, no country can successfully fight drug traffic without a functioning police and judicial system. While not war in the sense of armed conflict, it certainly ought to be considered a necessary component of the fight.

There is still some value to the concept of proportion, even if it is "unrefined and imprecise," and most people would agree that "we know much better what disproportionality is than proportionality" (Orend, 2006: 60). The concept can serve as a guide or a constraint, even if it is not a concrete formula. It is something qualitative rather than quantitative. By this line of reasoning, we know when war is a 
disproportionate response to a problem, and yet U.S. leaders are fond of calling their responses to a variety of problems "war." Perhaps the U.S. public has become accustomed to overly aggressive solutions. Perhaps we are accustomed to using guns and the military to confront problems because we have so many of both at our disposal. In the case of the war on drugs, though, we must consider whether it is proportionate and appropriate to involve the military in matters of law enforcement. One might argue that the line between the two has to be blurred in order to compete with the money and arsenals the drug trafficking organizations have at their own disposal, especially at the international level. The danger at the domestic level comes, as we have seen, when law enforcement personnel act like soldiers in a war zone and disregard procedure and the rule of law in a democracy, and when the citizens in turn take matters into their own hands.

One wonders if drug traffickers and suspected traffickers are treated differently when taken into custody or when processed for extradition. They do not clearly fall into the war captives category so much as the criminal category. And yet, the war involves both military and police so it is not clear whether they should be treated as suspected criminals or as prisoners of war - assuming they are taken prisoner at all and not killed in an exchange of fire with the authorities instead. Equally problematic is that Dominican citizens are less concerned that those who are taken into custody are treated and processed properly, and are more concerned that they are not treated more harshly. Corruption has eliminated any attachment to the principle of innocent until proven guilty, or concern that anyone might be falsely accused. 
"Just war theory and international law command...that you may only attack the true adversary in warfare (i.e. that entity directly engaged in physical harm)" and thus many would claim police actions that result in the deaths of traffickers are in fact justified (Orend, 2006: 113). But this also provides another complication for the war on drugs. Which is the entity directly involved in physical harm? Is it the growers who are causing physical harm? Some, along with the drug refiners and processors, may be physically harming and degrading the natural environment. The traffickers violate the law and often harm each other in disputes over money or turf, or harm those who are trying to stop them. Or is it the drug users who harm themselves with drugs? In a society that values security most, could it become permissible to eliminate all who use drugs as enemy combatants and without due process? The "exchange of fire" tactic could be used to reduce demand for drugs by killing off consumers in the same way that it has been deployed to remove supply and suppliers. Harm reduction advocates suggest there may be more justice in providing treatment instead and limiting the use of force against those on the wrong side of the law. Abandoning all restraint in war, including forgetting the opponent's humanity, eliminates the hope for peace and an end to conflict (French, 2007). The way drugs, drug traffickers, and those who grow the crops and produce drugs have been demonized by the war on drugs allows us to forget the human beings involved at every step.

Reed and Ryall (2007) propose an additional jus as bellum criterion: the pursuit of peace. Their other criteria are not drastically different from those posed by most scholars and thinkers in the history of just war theory, but the idea of war in the pursuit of peace has not been discussed extensively here. It may prove fruitful to consider it in the 
context of the case study, and again to recognize the limitations in the war on drugs as one that might not be winnable. "The peace that must be the goal of a justified war is neither a purely military victory nor the absence of violence, but the restoration of community" (Reed and Ryall, 2007: 12). Peace in the war on drugs may be conceived of as a community where no one needs the money gained from the drug trade because they have other viable means of income, or a community where no one desires the effects from the use of drugs. The first may be easier to achieve than the second, particularly when one considers the often competing moral or religious values and standards in relation to drug use throughout the world. For example, an altered state induced by drugs is considered one where a person is without the spirit in many Christian traditions, but other groups may view the use of altered states as a way to commune with gods or spirits. The religious tolerance that is a part of the U.S. Constitution does not extend to recreational cocaine use in this way, but we can still call into question the idea of extending one society's rules worldwide and to communities where ritual use of coca leaf is historically and culturally significant. As noted in the INCSRs, this can certainly be source of tension between nations.

The restoration of community, or more exactly, the creation of community through institution building, seems to be at the heart of the U.S. war on drugs in the Dominican Republic and the Dominican policies and programs of the PSD. How well these efforts are working is still not entirely clear, as the preceding chapters demonstrate. It is a question of proportion as the programs are in their early stages, and real results may not be possible without more comprehensive, systematic, and consistent implementation. Involvement of the domestic community and civil society, as well as the 
international community, will be key to rooting out corruption and keeping the successful elements of the programs going.

\section{Conclusions}

It is difficult to talk about drug control without using words like "fight" and "combat," but the case of the Dominican Republic suggests that our emphasis should shift from war to justice and community building, not to mention the treatment of drug abuse as a health issue rather than a crime. Justice is a police force that serves the people, is paid a decent wage so officers are less likely to be corrupted, and whose officers know the procedures for handling suspects and placing them in the system for processing. Justice is a system where there is due process of law, that is free of corruption, and where few are tempted to make or accept bribes. Clearly this ideal kind of system takes time to develop. Corruption and patronage cannot be eliminated overnight. The ideas are there and efforts are being made. Despite some shortfalls, improvements have been made and some of the obstacles that still need to be addressed have been brought to light. One must ask whether it is just to spend money on airplanes, for instance, when the Dominican Republic could benefit as much or more from investments in energy, education, economic reform and control of money laundering, and continued expanded police reform.

A shift from war to justice could also be made in the U.S. through increased efforts at demand reduction, treatment for addicts, and equitable treatment and logical classification under the law of drugs themselves. This may take the form of following the lead of countries like the Netherlands and Spain to decriminalize certain drugs, and to place the focus of interdiction efforts and valuable resources on others that are the most 
addictive and lethal. If reform of policy in the U.S. means demand reduction and treatment, then in the Dominican context it has to mean addressing basic societal elements that allow the drug trade to infiltrate the economy. It means infrastructure and economic development; programs like Barrio Seguro are an attempt to re-create and reform specific elements of local and national infrastructure and institutions that have been affected by drug crime.

Drugs infiltrate a state in one of two ways: The organization buys off someone at the top who controls many others below him or her, or it buys off so many people at lower levels that it becomes impossible for anyone at the top to control and reign in the others. Both have happened in the Dominican Republic. The Fernández administration's implementation of the PSD is an attempt to recreate and reform institutions in order to get rid of corruption and prevent future corruption, from the top down and bottom up simultaneously. These efforts have been successful and not so successful, depending on whom you ask. There is also no doubt that the drug trade is rich and corrupt. They will always seek someone to buy off and have the means to do so. Unfortunately, in a state like the Dominican Republic, there are likely to be plenty to choose from.

The war on drugs depends on functional military organizations. Dominican forces were too small to deal with the amount of coastline available to would-be smugglers, nor could the army deal with the entire land border with Haiti. Cooperative efforts with the U.S. and other nations in the Caribbean have helped to address these issues. At the same time, the war on drugs has further exposed additional internal institutional weaknesses. As more drugs entered the country, crime increased to the point that the state, especially the newly democratic government, could no longer ignore it. By 
trying to create and achieve a police force capable of competently dealing with drugs and drug-related crimes, corruption within the system that may have been tolerated or denied for years was ultimately exposed.

The Dominican response to the war on drugs has been to increase the state presence in the country, but in a way that respects democratic ideals and popular sovereignty. Unfortunately, at the same time there are negative unintended consequences to declaring a war on drugs. The tone of the international drug war is one that allows undemocratic practices to continue, particularly the suspension or disregard of civil rights in a war zone. The idea that drug criminals are enemies allows violence without due process to continue. The continued militarization of the drug war may actually be undermining the U.S.'s goal to spread democracy throughout the world, especially where drugs are well entrenched but democracy is not. Rigidity in policy circles, supported by righteousness in some cases, makes creating justice and balance or proportion in this war a near impossibility.

At first glance, this study may appear to show that the war on drugs in the Dominican Republic has been a failure or had very little effect, if any, at stopping the movement of drugs through the country and into the U.S. If we are only looking at that as the ultimate goal, then such a conclusion is merited. But if we consider that the international war on drugs, led by the U.S., has spawned additional internal efforts to improve a variety of institutions that are involved with the various aspects of drug control, then it becomes clear that the cascading effects of the policy may ultimately find success. Perhaps the first person to utter the phrase "war on drugs" never imagined that it could include the tactic of reforming a civilian police force and judicial processes, or a 
strategy to provide scholarships and housing assistance to the poor, but perhaps this is precisely where more effort needs to be made. Law enforcement clearly should be a part of the picture, and efficiency and adherence to principles and procedure are a vital part of the reform process. Even so, demand for drugs does not necessarily decrease in the presence of a capable police force. The U.S. and many European countries know this all too well. Myriad conditions increase the probability of drug use, abuse, and profiteering, especially a lack of education and opportunities for sufficient employment. By moving away from the war metaphor, a broader strategy can be employed. For those who wish to keep the war allegory, perhaps they would incorporate the idea of post-war rebuilding into future policy plans.

\section{Epilogue - War on Supply vs. War on Demand: Policy Alternatives}

We cannot legislate our way out of the drug problem by passing mandatory sentencing and asset forfeiture laws, we cannot police our way out of the drug problem by further expanding narcotic enforcement activities both domestically and internationally, and we cannot build our way out of the drug problem by constructing more penitentiaries and prison cells. The alternative is sciencebased treatment and prevention activities to reduce the demand for drugs. For after all, if there were no drug users, there would be no drug problem (Inciardi, 2008: 321).

As I write this, more than 30 defendants in the Baní case are preparing to go to trial, and drug violence is reasserting itself along the Mexico-U.S. border and within the Southern United States. No matter what the positive outcomes of the PSD and Barrio Seguro programs in the cities, there is still widespread corruption and infiltration of drug interests in the far reaches of the Dominican Republic. Whether the state is equipped to expand its programs and confront the problem to its fullest extent remains to be seen. A further 
shifting of drugs routes out of the Caribbean is likely to continue, once again raising the question of whether the interdiction strategy is effective in the long run.

History and trends show a tendency toward "abuse of almost any substance that promises significant changes in perception and consciousness" especially among teens and adults in the U.S. and Western Europe (Inciardi, 2008: 86). Historically there has been a neglect of demand reduction in U.S. policy, though more recently the sentiment that the supply reduction strategy is not effective has been growing (Boyum and Reuter, 2005). Interdiction efforts only reduce imports of drugs into the U.S. by about tenpercent at most, and inspection of cargo is costly, paralyzing to ports and markets, and potentially lethal to some countries' economies (Nordstrom, 2007). On the other side, the merits of legalization are speculative at best, and the repeal of drug laws does not have support within either political party in the U.S.

I was not certain about including this subsection as part of the dissertation, but I feel it does merit at least some mention when one is discussion drug policies. During the time I spent researching and writing about the topic, I heard stories in the news almost daily about this celebrity or that caught using drugs - or worse, dead from them. For young and old alike, it seems a trip to rehab or a mug shot is par for the course for those we call famous. The demand for drugs is alive and well in our country, and even celebrated by some. So what place do demand reduction, harm reduction, and decriminalization have in the drug war? We can argue that proportion in the war on drugs also means the balanced and equal treatment of demand as well as supply. Might some of these strategies prove to be effective - and if so, more just - than the use of armed force against the supply side? 
Drugs are a veritable hydra monster of a problem. As previously discussed, when the head of crop production or trans-shipment is cut off in one area, another one tends to grow elsewhere and quickly. The monster analogy also applies to demand - heroin and LSD consumption in the 1960s was replaced by cocaine in the 1970s and 1980s; the crack epidemic the Reagan administration so adamantly fought against and tried educate children and youth about seems to have been replaced now by rave culture and the popularity of party drugs like ecstasy. The same "Just Say No" generation is at the helm of efforts to address the rising tide of methamphetamine, or crystal meth, consumption, a drug made in the U.S. Recent data from various surveys conducted in the U.S. show that young people, ages 12 to 25 , are more likely to abuse prescription drugs - pain relievers specifically - than cocaine (Inciardi, 2008). But demand is not just a U.S. or European phenomenon. Cocaine has re-emerged in Brazil from the 1990s onward, especially in the large urban slum areas as well as its "pleasure spots" that make for good transshipment zones, and Brazil is today the second largest consumer of cocaine after the United States (Bagley, 2009; Gootenberg, 2008). According to the DNCD, Ketamine, aka Special K, has recently come on the scene and gained popularity among recreational drug users in Santo Domingo (DR1 Daily News, July 24, 2007). Near the end of the time period under investigation here, additional evidence has been found that drug consumption has increased in the Dominican Republic, while prices have fallen (DR1 Daily News, September 6, 2007). In particular, the $\mathrm{CDN}$ found that consumption among grade school and middle school students has increased between 2005 and 2009 (Hoy, February 24, 2009). 
Except for recent cuts, over the years the budget for the war on drugs has increased in total but the proportions delegated for supply and demand reduction stay the same, in spite of little evidence of the benefits from the war on supply, while the benefits of treatment are more tangible and measurable. It has been said that if all drugs were decriminalized and if narcotics were dispersed by medical doctors to addicts, the problem would eventually go away with education. Inciardi (2008) shows that treatment efforts can help increase employment among former addicts, reduce crime, and reduce costs for hospitals and the criminal justice system. He also suggests that this means something about the relative importance of supply and demand reduction. More efforts in the latter could provide cascading effects for the former.

Stopping production and traffic is only part of the equation. In the spirit of capitalism, suppliers will always seek to fulfill a demand. The criminal nature of drugs only makes doing so more profitable. Is the removal of the profit incentive and regulation by government at all viable? We might be able to draw some lessons from the country's experience with prohibition. But if the rhetoric of the drugs war makes drugs the embodiment of pure evil, discussion of these options may never happen.

The USG is officially opposed to harm reduction, seeing it as a slippery slope. It is neither a policy nor a program specifically, but is instead the idea that the problem of drug abuse should be managed since trying to eliminate it all together would be impossible. Agencies like the Center for Disease Control \& Prevention, National Institutes of Health, and Department of Justice have been practicing harm reduction for years, though perhaps under a different name. Diversion programs in place of jail time for drug offenses are one example from the justice system. Unfortunately, there has been 
little comprehensive evaluation of most diversion or treatment programs in general. Treatment is known to work, yet each treatment center is different and uses different methods. Thus, alternatives to incarceration are only as good as the treatment programs to which the offenders are sent. At current rates of funding, there are not enough to meet the need, either in the public sector or within the prison system. Much like with the police and judicial reform programs in the Dominican Republic, more consistent implementation is needed in order to achieve the desired results.

Thoumi (1995) argues that there are two kinds of policy approaches to the drug problem: moralistic and pragmatic.

The degree of success of moral-based policies depends... on the existence of a wide normative consensus in the society about imposing social and moral constraints on individuals and /or on a strong, authoritarian government that believes in those constraints and is willing to impose policies on society that sacrifice individual freedoms (Thoumi, 1995: 276).

Whether moralistic or pragmatic, policies will also be affected by other factors, such as policy constituencies or groups that have a particular interest in keeping a policy in place. The political force of moralistic vantage points as well as policy constituencies can make changing a policy difficult, even if it is not very effective from a practical standpoint. This truly seems to be the case with illegal drugs in the Americas. Whether U.S. decision makers can move away from the moralism that is embodied in drug policy and the rhetoric of the war on drugs to something more practical is questionable. Those who work in drug enforcement want to keep their jobs, and those who set policy are constrained by public opinion that shares the same moral slant. It is my hope that continued research on all sides of the drug issue will eventually help to shift policy in the direction of pragmatism. 
"If peripheral sites and actors had much to do with the making of cocaine in the first place, perhaps their renewed agency (or conscious resistance) can help undo the global drug conflict that has enveloped this drug since the 1980s" (Gootenberg, 2008: 319). In other words, the solution is not necessarily to be found within the U.S.'s imposed prohibitions. We will need cooperative arrangements that incorporate best local practices and most important an openness to other ways of viewing the drug and its reach. 


\section{LIST OF REFERENCES}

Primary Sources:

CIA World Fact Book, 2008.

Consejo de Gobierno Ampliado Sobre Seguridad Democrática. (July 24, 2006).

EEUU anuncia plan contra narcos. (2007. February 3). Listin Diario. Retrieved from www.listindiario.com March 11, 2007.

Encuesta de Evaluación - Plan de Seguridad Democrática. (May 2008). Newlink Research. Santo Domingo.

Encuesta de Percepción - Barrio Seguro. (September 2006). Centro de Estudios Sociales Padre Juan Montalvo, S.J. Santo Domingo.

Encuesta Interna: Policía Nacional. (August 2007). Secretaria de Estado de Interior y Policía. Santo Domingo: Editorial Gente.

Encuesta Interna: Policía Nacional, Capitulo Comunicaciones. (September 2007). Plan de Seguridad Democrática/Secretaria de Estado de Interior y Policía. Santo Domingo: Editorial Gente.

Encuesta 16 Barrios, Distrito Nacional. (November 2006). Secretaria de Estado de Interior y Policía/Plan de Seguridad Democrática. Santo Domingo: Editorial Gente.

Espinal, R. (2008). Telephone conversation with author. October 31.

Estudio sobre el Ministerio Público en la República Dominicana. (March 1998). La Fundación Institucionalidad y Justicia (FINJUS): Santo Domingo.

Evaluación del Plan de Seguridad Democrática (Informe Confidencial). (June 2008). Newlink Research, Santo Domingo.

Evaluación Estratégica: Dirección Central Asuntos Internos, Ano 2006 - Septiembre 2007. (October 9, 2007). Report created and presented by Major General Vinicio A. Hernandez, Director Central de Asuntos Internos, Policía Nacional.

Indice de Desarrollo Democrático de América Latina. (2007). Available online at http://www.idd-lat.org/Briefing2007.htm 
Informe de Gestión de la Policía Nacional en la Implementación del Plan de Seguridad Democrática, Agosto 2005 - Diciembre 2006. Presentation at conference of the Policía Nacional, June 26, 2007, Juan Dolio, Dominican Republic.

International Narcotics Control Strategy Report. (March 2007). Bureau of International Narcotics And Law Enforcement Affairs, United States Department of State. Retrieved March 4, 2007 from www.state.gov/p/inl/rls/nrcrpt/2007/voll/html/

International Narcotics Control Strategy Report. (1996 through 2006). Bureau of International Narcotics and Law Enforcement Affairs. Retrieved from the State Department Website and online archives.

Lacey, M. A subway just what's needed. Or is it? (2007. September 3). New York Times.

Lineamientos de la política criminal dentro de los parámetros del Plan de Seguridad Democrática para la República Dominicana. (2005). Procuraduría General de la República (PGR): Santo Domingo.

Manual de organización del estado Dominicano ( $8^{\text {th }}$ ed). (2004). Presidencia de la República, Oficina Nacional de Administración y Personal (ONAP): Santo Domingo.

Percepciones y Expectaciones sobre la Seguridad en Barrios del Distrito Nacional y Santiago: Resultado del Estudio Cualitativo y Cuantitativo Newlink Political. (December 2006). Retrieved from www.seip.gov.do/proyectos/psd/diagnostic y recomendaciones

Plan Provincial de Lucha Contra las Drogas. (January 2007). Mesa de Coordinación sobre política anti-narcóticos de la Provincia de Santiago. Santiago, R.D.: NBSimé Comunicación Grafica.

Polanco, B. (2008). Interview by author. Santo Domingo, Dominican Republic, November 12.

Situación de la pobreza y distribución del ingreso en la República Dominicana. (July 1999). Report by Banco Central: Santo Domingo.

Vargas, T. (2008). Interview by author. Santo Domingo, Dominican Republic, November 14.

Various articles. (2006 - 2009). DR1 Daily News. Via daily e-mail subscription from www.dr1.com.

Various articles. (2006 - 2009). Listin Diario. Retrieved from www.listindiario.com. 


\section{Secondary Sources:}

Abrams, E. (Spring 1996). The shiprider solution: Policing the Caribbean. The National Interest 43, 86-92.

Amiama, M.A. (1995). Notas de derecho constitucional. Santo Domingo, Dominican Republic: Editorial TIEMPO, S.A.

Amstutz, M.R. (2005). International Ethics: Concepts, theories, and cases in global politics. Lanham, MD: Rowman and Littlefield Publishers, Inc.

Aydinly, E. and Rosenau, J., (Eds.). (2005). Globalization, security, and the nation state: Paradigms in transition. Albany: State University of New York Press.

Bagley, B. (2007). U.S. Drug control policies in Latin America. Seminar on drug, security and hemispheric cooperation. Santo Domingo, Dominican Republic. March 12, 2007.

. (2009). "Whatever happened to the war on drugs in Latin America?" Lecture at Florida International University, November 5.

Bagley, B.M. and Walker, W.O., (Eds.). (1994). Drug trafficking in the Americas. New Brunswick: Transaction Publishers.

Beruff, J.R. (2000). 'Narcodemocracy' or Anti-drug Leviathan: Political Consequences of the Drug War in the Puerto Rican High-Intensity Drug-Trafficking Area. In I. Griffith (Ed.), The Political Economy of Drugs in the Caribbean (pp. 162-182). New York: St. Martin's Press.

Beruff, J.R. and Cordero, G. (2005). The Caribbean: The "third border" and the war on drugs. In Youngers, C. and Rosin, E. (Eds.), Drugs and democracy in Latin America: The impact of U.S. policy (pp. 303-337). Boulder: Lynne Rienner Publishers.

Bethke Elshtain, J. (2007). Terrorism. In C. Reed and D. Ryall (eds.), The price of peace: Just war in the twenty-first century (pp. 118-135). Cambridge: Cambridge University Press.

Bollen, K. A. (1991). Political democracy: Conceptual and measurement traps. In A. Inkeles (Ed.), On measuring democracy: Its consequences and concomitants (pp. 3-20). New Brunswick, NJ: Transaction Publishers.

Boyum, D. and Reuter, P. (2005). An analytic assessment of U.S. drug policy. Washington, D.C.: The AEI Press. 
Brana-Shute, G. (2000). Narco-Criminality in the Caribbean. In I. Griffith (Ed.), The Political Economy of Drugs in the Caribbean (pp. 97-112). New York: St. Martin's Press.

Caceres, B. (1978) La coca, el mundo Andino, y los extirpadores de idolatrías del Siglo XX. América Indígena 38.4, 769-785.

Callaghan, J. and Kernic, F., (Eds.). (2003). Armed forces and international security: Global trends and issues. Piscataway, NJ: Transaction Publishers.

Cepeda Ulloa, F. (1994). International cooperation and the war on drugs. In Bagley, B.M. and Walker, W.O., (Eds.). Drug trafficking in the Americas (pp. 513-520). New Brunswick: Transaction Publishers.

Chester, E.T. (2001). The U.S. intervention in the Dominican Republic, 195-66: Ragtags, scum, riff-raff, and commies. New York: Monthly Review Press.

Christopher, P. (2004). The ethics of war and peace: An introduction to legal and moral issues (Third Edition). Upper Saddle River, NJ: Pearson/Prentiss Hall.

de la Peña Begué, R. (1971). El uso de la coca en América, según la legislación colonial y republicana. Revista Española de Antropología Americana 6, 179-204.

Democracy in Latin America: Towards a Citizen's Democracy ( $1^{\text {st }}$ English ed.). (2005). New York: United Nations Development Programme.

Dorn, N., Murji, K., and South, N. (1992). Traffickers: Drug markets and law enforcements. New York: Routledge.

Evans, M., (Ed.). (2003). International law (1 ${ }^{\text {st }}$ ed.). New York: Oxford University Press.

Farer, T., (Ed.). (1999). Transnational crime in the Americas. New York: Routledge.

French, S.E. (2007). An American military ethicist's perspective. In C. Reed and D. Ryall (eds.), The price of peace: Just war in the twenty-first century (pp. 295303). Cambridge: Cambridge University Press.

Gagliano, J. (1994). Coca prohibition in Peru: The historical debates. Tucson and London: University of Arizona Press.

Gaines, L.K. and Kraska, P.B. (Eds.). (1997). Drugs, crime, and justice: Contemporary perspectives. Prospect Heights, IL: Waveland Press, Inc. 
Gootenberg, P. (2008). Andean cocaine: The making of a global drug. Chapel Hill: The University of North Carolina Press.

Griffin, C. (2000). Democracy and Political Economy in the Caribbean. In I. Griffith (Ed.), The Political Economy of Drugs in the Caribbean (pp. 113-137). New York: St. Martin's Press.

Griffith, I. (1997). Drugs and Security in the Caribbean: Sovereignty Under Siege. University Park: Pennsylvania State University Press. . (2000a). Introduction: Drugs and Political Economy. In I. Griffith (Ed.), The Political Economy of Drugs in the Caribbean (pp. 1-7). New York: St. Martin's Press. . (2000b). Drugs and Political Economy in a global village. In I. Griffith (Ed.), The Political Economy of Drugs in the Caribbean (pp. 11-28). New York: St. Martin's Press.

Haggard, S. and Kaufman, R. (1995). The political economy of democratic transitions. Princeton: Princeton University Press.

Hartlyn, J. (1998). The Struggle for Democratic Politics in the Dominican Republic. Chapel Hill: The University of North Carolina Press.

Hinojosa, V. (2007). Domestic Politics and International Narcotics Control: U.S. relations with Mexico and Colombia, 1989-2000. New York: Routledge.

Inciardi, J.A. (2008). The war on drugs IV: The continuing saga of the mysteries and miseries of intoxication, addiction, crime, and public policy $\left(4^{\text {th }}\right.$ ed.). Boston: Pearson/Allyn and Bacon.

Isacson, A. (2005). The U.S. military in the war on drugs. In Youngers, C. and Rosin, E. (Eds.), Drugs and democracy in Latin America: The impact of U.S. policy (pp. 15-60. Boulder: Lynne Rienner Publishers.

Isacson, A., Haugaard, L., and Olson, J. (Nov.- Dec. 2004). Creeping militarization in the Americas. NACLA Report on the Americas 38.3, 4-7.

Jones, M. (July 2002). Policy Paradox: Implications of U.S. Drug Control Policy for Jamaica. The Annals of the American Academy of Political and Social Science $582,117-133$.

Joyner, C. (2005). International law in the $21^{\text {st }}$ century: Rules for global governance. Lanham, MD: Rowman \& Littlefield Publishers, Inc. 
Kaufman, W. (December 2005). What's wrong with preventive war? The moral and legal basis for the preventive use of force. Ethics \& International Affairs 19.3, 23-38.

Kincaid, A.D. and Gamarra, E. (1996). Disorderly Democracy: Redefining public security in Latin America. In R. P. Korzeniewicz and W. C. Smith (Eds.), Latin America in the world-economy (pp. 211-228). Westport, CT: Greenwood Publishers.

Klein, A., Day, M., and Harriot, A., (Eds.). (2004). Caribbean Drugs: From criminalization to harm reduction. Kingston: Ian Randle Publishers.

Kraska, P.B. (1997). The military as drug police: Exercising the ideology of war. In L.K. Gaines and P.B. Kraska (Eds.). Drugs, crime, and justice: Contemporary perspectives (pp. 297-320). Prospect Heights, IL: Waveland Press, Inc.

Linz, J. (1978). The Breakdown of Democratic regimes: Crisis, Breakdown, Reequilibration. Baltimore: The Johns Hopkins University Press.

Livingstone, G. (2004). Inside Colombia: Drugs, democracy, and war. New Brunswick: Rutgers University Press.

Lowenthal, A. F. (1972). The Dominican intervention. Cambridge: Harvard University Press.

Mabry, D.J. (1994). The U.S. military and the war on drugs. In Bagley, B.M. and Walker, W.O., (Eds.). Drug trafficking in the Americas (pp. 43-60). New Brunswick: Transaction Publishers.

MacCoun, R and Router, P. (July 2002). The Varieties of Drug Control at the Dawn of the Twenty-First Century. The Annals of the American Academy of Political and Social Science 582, 7-19.

McAllister, W.B. (1994). The international nexus: Where worlds collide. In Bagley, B.M. and Walker, W.O., (Eds.). Drug trafficking in the Americas (pp. 521-534). New Brunswick: Transaction Publishers.

McMahan, J. (December 2005). Just cause for war. Ethics \& International Affairs 19.3, $1-21$.

Meruvia Balderrama, F. (2000). Historia de la coca: Los yungas de Pocona y Totora (1550-1900). La Paz: Plural Editores.

Mortimer, W.G. (1974). History of coca "Divine Plant of the Incas". 1901. Fitz Hugh Ludlow Memorial Library Ed. San Francisco: AND/OR Press. 
Moya Pons, F. (1995). The Dominican Republic: A national history. New Rochelle, NY: Hispaniola Books.

Musto, D.F. (1997). Opium, cocaine, and marijuana in American history. In L.K. Gaines and P.B. Kraska (Eds.). Drugs, crime, and justice: Contemporary perspectives (pp. 21-33). Prospect Heights, IL: Waveland Press, Inc.

Neild, R. (2005). U.S. police assistance and drug control policies. In Youngers, C. and Rosin, E. (Eds.), Drugs and democracy in Latin America: The impact of U.S. policy (pp. 61-97). Boulder: Lynne Rienner Publishers.

Nordstrom, C. (August 10, 2007). What the Highwayman Knew. The Chronicle of Higher Education, B10-B11.

O’Donnell, G. and Schmitter, P. (1986). Transitions from authoritarian rule: Tentative conclusions about uncertain democracies. Baltimore: The Johns Hopkins University Press.

Orend, B. (2006). The Morality of War. Orchard Park, NY: Broadview Press.

Palmer, B. (1989). Intervention in the Caribbean: The Dominican crisis of 1965. Lexington: University of Kentucky Press.

Payan, T. (2006). Cops, soldiers, and diplomats: Explaining agency behavior in the War on Drugs. Lanham, MD: Lexington Books.

Perez, M.A., (Ed.). (1978). Las fuerzas armadas en la sociedad civil (Alemania, USA, URSS y América Latina): contribución de CISEC a la Conferencia Episcopal para el Diseño de la Pastoral de la Iglesia. Santiago, Chile: CISEC.

Ramirez, E.C. \& M. Brea de Cabral. (2003). Violencia en la República Dominicana: Tendencias recientes. Perspectivas Psicológicas, 3-4.

Reed, C. and Ryall, D. (2007). Introduction. In C. Reed and D. Ryall (eds.), The price of peace: Just war in the twenty-first century (pp. 1-15). Cambridge: Cambridge University Press.

Rogers, J. (1999). Political Economy of Drug Trafficking: The Case of the Dominican Republic. FIU Doctoral Dissertation, Green Library.

Rosenau, J. (1990). Turbulence in world politics: A theory of change and continuity. Princeton: Princeton University Press. . (1997). Along the domestic-foreign frontier: Exploring governance in a turbulent world. Cambridge: Cambridge University Press. 
Saignes, T. (1988). Capoche, Potosí, y la Coca: El consumo popular de estimulantes en el Siglo XVII. Revista de Indias 48.182-3, 207-235.

Sánchez, A. (1997). 'El Talismán del Diablo' La Inquisición frente al consumo de coca. Revista de la Inquisición 6, 139-162.

Shaw, M. (2003). International law (5 $5^{\text {th }}$ ed.). Cambridge: Cambridge University Press.

Skolnick, J.H. (1997). Rethinking the drug problem. In L.K. Gaines and P.B. Kraska (Eds.). Drugs, crime, and justice: Contemporary perspectives (pp. 403-426). Prospect Heights, IL: Waveland Press, Inc.

Temes, P.S. (2003). The just war: An American reflection on the morality of war in our time. Chicago: Ivan R. Dee.

Thompson, A. (1997). The haunting past: Politics, economics and race in Caribbean life. New York: M.E. Sharp, Inc.

Thoumi, F. (1995). Political Economy \& Illegal Drugs in Colombia. Boulder: Lynne Rienner Publishers.

Tickner, J. (1997). You Just Don't Understand: Troubled Engagements Between Feminists and IR Theorists. International Studies Quarterly, 41, 611-632.

Walzer, M. (1977). Just and Unjust Wars: A moral argument with historical illustrations. New York: Basic Books.

Wayne, L. (2006. October 31). Free to a good country; castoff military gear for America's allies. The New York Times.

Weigel. G. (2007). The development of just war thinking in the post-Cold War world: An American perspective. In C. Reed and D. Ryall (eds.), The price of peace: Just war in the twenty-first century (pp. 19-36). Cambridge: Cambridge University Press.

Wheeler, M.O. (2007). A US political perspective. In C. Reed and D. Ryall (eds.), The price of peace: Just war in the twenty-first century (pp. 277-285). Cambridge: Cambridge University Press.

Youngers, C. (2005). The collateral damage of the U.S. War on Drugs: Conclusion and recommendations. In Youngers, C. and Rosin, E. (Eds.), Drugs and democracy in Latin America: The impact of U.S. policy (pp. 339-366). Boulder: Lynne Rienner Publishers. 
Youngers, C. and Rosin, E. (Eds.). (2005). Drugs and democracy in Latin America: The impact of U.S. policy. Boulder: Lynne Rienner Publishers.

. (2005). The U.S. "War on Drugs": Its impact in Latin America and the Caribbean. In Youngers, C. and Rosin, E. (Eds.), Drugs and democracy in Latin America: The impact of U.S. policy (pp. 1-13). Boulder: Lynne Rienner Publishers. 
VITA

\section{LEAH HUTTON BLUMENFELD}

1999

2003

2004-2008

2008-2010
ALB, Humanities

Harvard University

Cambridge, MA

MA, International Studies

University of Connecticut

Storrs, CT

Teaching Assistant

Florida International University

Miami, FL

Graduate Assistant

Florida International University

Miami, FL

\section{PUBLICATIONS AND PRESENTATIONS}

Research Presentation: "Justice in the War on Drugs: The Dominican Experience with Police Reform." $2^{\text {nd }}$ Annual Graduate Student Conference on Democracy and Democratization, University of Connecticut, February 27, 2010.

Moderator: "Dance, Gender, and Culture.” Panel Discussion, Women's Studies Center, Florida International University, October 15, 2009.

Research Presentation: “Applying Just War Theory to the War on Drugs.” International Ethics in Times of Insecurity: A Mini Conference, Florida International University, February 20, 2009.

Acknowledgements: Inside Defense: Understanding the U.S. Military in the $21^{\text {st }}$ Century, edited by Derek S. Reveron and Judith Hicks Stiehm, 2008. New York: Palgrave MacMillan.

Research Presentation: “Just War Doctrine and the War on Drugs." Georgia Political Science Association Annual Meeting, Savannah, GA, November 16, 2007.

Research Presentation: "The Political Economy of Tourism: Women and Labor in the Caribbean." The $18^{\text {th }}$ Annual Conference on Women and Gender, University of Connecticut, March 31, 2006. 
Research Presentation: "Habitual Policy: U.S. - Cuba Relations in the 1990s." 30" Annual Conference of the Caribbean Studies Association, Santo Domingo, Dominican Republic, June 3, 2005.

Research Presentation: "Political Decentralization in Bolivia and Colombia." $10^{\text {th }}$ Annual Latin American Social and Public Policy Conference, University of Pittsburgh, February 17, 2005.

\section{SERVICE}

Member, Planning Committee: City of Miami Beach First Annual Women's Conference, March 2009.

Member, Miami-Dade County Commission for Women, June 2009 - present. 